University of Louisville

ThinkIR: The University of Louisville's Institutional Repository

Electronic Theses and Dissertations

6-1916

\title{
Some aspects of Madison Cawein's poetry.
}

Julia C. King

University of Louisville

Follow this and additional works at: https://ir.library.louisville.edu/etd

\section{Recommended Citation}

King, Julia C., "Some aspects of Madison Cawein's poetry." (1916). Electronic Theses and Dissertations. Paper 755.

https://doi.org/10.18297/etd/755

This Master's Thesis is brought to you for free and open access by ThinkIR: The University of Louisville's Institutional Repository. It has been accepted for inclusion in Electronic Theses and Dissertations by an authorized administrator of ThinkIR: The University of Louisville's Institutional Repository. This title appears here courtesy of the author, who has retained all other copyrights. For more information, please contact thinkir@louisville.edu. 
SOME ASPRCTS OF MADISON CAWRIN'S POETRY

A $\quad \underline{\underline{H}} \underline{\mathrm{E}} \underline{\mathrm{S}} \mathrm{I} \underline{\mathrm{S}}$

SUBMITTED TO THE FACULTY OF THE

COITEGR OF ARTS AND SCIBACES

OF THE

UNIVARSITY OF IOUISVILIE

IN CANDIDACY FOR THR DEGRES

$\underline{O F}$

MASTER OF ARTS

$\underline{B Y}$

J U I I $\mathrm{A}$ C. $\underline{\mathrm{K}} \mathrm{I} \underline{\mathrm{N}} \mathrm{G}$. JUNE 1916. 
HULAN FILENEBNT OF HIS POETRY

Historic Periods

Human Poetry of Wordsworth

Human Poetry of Tennyson

Human Poetry of Shelley

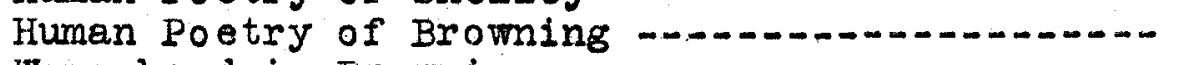

Womanhood in Browning -........

CAUTEIN AS COMPARED VITH THEST POBTS _.............

\section{IF.}

THE METRIQUE OF MADISON CAWEIN'S POETRY _...... 118 Madison Cawein's Verses Range, Inclusively, From one-Stress to Seven-stress Rhythm

His Stanzas Inciude Couplets, Tercets, Quatrains and Stanzas From Five to Fourteen Iines Inclusive

His Poetry Includes Lypics, Ballads, Sonnets, Blank Verse and Dramas

1. The Arthurian cycle is the Source of Some of Cawein's Metrical Romances and Idylis

II. Cawein's Relationship to Other Arthurian Poets 
VI •

Page

CAWEIN'S BALLADS BEAR SPECIFIC MARKS OF OID

ENGLISH AND SCOTCH BALLADRY _.... 173

1. Some Characteristics of the Technique of Old Balladry:

1. The Ballad Has Choral Origin .......... 174

2. Refrain and Incremental Repetition .... 176

3. Popular Motifs of 0ld Ballads ....... 179

4. Ballad Metrique - 190

11. Cawein's Ballads Bear Specific Marks of Old Balladry 191 
1.

FELIaIOI AND PHILOSOPEX

OP

MADTBOS CAUTHX'S PORTRY. 


\section{RELIGTOY AND PHILOSOPHY OF YADISOY CAWEIN'S POETRY.}

After a careful study of ladison Cawein's poetry, and comparing his fiews on religion and phllosophy with those of some of the great Finglioh poets, Wordaworth, Shelley, Byron, Tennyson and Browning. I shall summarize them as follows, and treat each subject by comparison with these writers and with selections from his and their poems, substantiating these statements :

1. Cawrin's Conception of God 10 That God is the Fountain of all Mind, Beauty, Truth and Iove.

2. His Poetry imbodies the Iden of Panthel sm.

3. His Pootry Teaches the Evolution of the Soul.

4. Hig Poetry Bxpresses the Platonic Philosophy of Pre-Exis tenoe.

5. His Poetry Expresses a Bellef in the Immortality of the Soul.

6. His Poetry Does Not Treat of the Doctrines of Christianity. 
(1) GOD IS THE FOUNTAIM OF AIC MIND, TRUTH, BEAUTY, AND LOVR.

The spirituality of Cawein's potry reveals his concoption of God as the fountain of all mind, truth, beauty. and 107e; and the soul of man ia a spark of God's essence, clothed with Ilesh. Into his poetry, Cawein, like Wordsworth, shelley, and Broming, breathes a feeling of profound lore, worshlp, and mystery for the mighty Being of Infindty.

The lines which follor exprese the poet's conception of God:

\section{Destre.}

Thet lifto man upward, heart, and soul, and insind, From matter to 1doel potenoles,

Up to the source and fountain of all mind, Beauty and truth and everlasting love.

-.--n-n- The goul shell see

Resplendencies of empyrean light

Sw1ft - Ilghtening out of opherso harmonies:

Prims and facets of ten million beams

Starring a crystal of wild-ralnbowed rays:

And in 1t - eyes: of burning sapphire, eyes

Deep as the musle of the beautiful:

And o'or the eyes, Ilmpid hierarohal browe, As they wore lilies of seraphlo fire: 
I1ps underneath of trembling ruby - 21ps Whose 1. 1. 11ght and each expression song.

\section{Prelude I.}

WI sdom and Spirit of the Universet

Thou Soul that art the eterndty of thought. Wordsworth.

\section{Aonges.}

Wiere'or that Power may more Which wields the world with never-wearied love, Sustains it from beneath, and kindles it above. Shelley.

\section{Boipgyohidion.}

The winged words on which my soul would plerce Into the helght of Iove'g rare universe.

Shelley.

\section{The Sensitire Plent.}

And the upring arose on the garden fais Ilke the Spirit of Love felt everywhere. Sholley. 


\section{Evmn to Intelzeoture Beauty.}

Spirit of Beauty, that dost consecrate

Wi th thine own hues all thou dost shine upon

of human thought or form.

She120y.

\section{Hebrew yelodies.}

Creatures of clay - rain dwellers of the dust, Heedless and blind to 1 sdom's wasted light. Byron.

\section{Caln.}

God, the Eternall Infinstel All-wised

Who out of darkness on the deep didst make

Ilght on the waters with word; all hallt Byron.

\section{In Yomoriam.}

That God, which erer lives and loves,

One God, one law, one element.

Tennyoon.

Browning's concoption of God is that He is the porfeot Poot, Inflaite Mind and Lore, as the following lines show:

\section{Paracelsus.}

God 1: the perfeot poet. 
Oodl Thou art mind Unto the master-mind Mind should be preolous.

Godl Thou art lovel I build my fal th on that. Take mo to thysedf

Eternal, Infinite lorel 
(2) HIS POBTRY FMBODIIS THE IDAA OF PANTHEISY .

Pentheism is that system of philosophy which in its spiritual form identifies the universe with God, and, in 1 to material form, God wh the univorse, dating back to the old Hindu doctrine that matter and mind are both absorbed into the fathomless abyss of 11limitable and absolute being. The Mosalo account of oreation exoludes any pantheistio cosmogony.

Spdnoza is perhapg the greatest and most rigorous panthelst the world has knom.

Nel ther Bngland, Branee, nor Anori on has produced a great panthe1stic philosopher.

The idea of panthei abounds in 11terature, and we frequently find it in Cawain's poetry, expressing a beliof that God 1s the onimating Spirit of the universe, and also a belief in remabsorption by Nature after death. In this conception Cawein is 21ke shelley and other poets of the Nineteenth Century. The fellowing seleotiona ambody the idea of pantheian:

\section{Intimations of the Beautiful.}

A spint oparkies in the dow,

The trees have tongues that speak to me.

\section{In Sol1tary places.}

A brotherbood that preant unwordable

In overy tree, in overy stream you meet: 


\section{Store.}

I looked into the night and an

God weiting with tumul thous rlame.

\section{Yreter 1ne.}

The murmured musis cod breathes alway

Through the hearts of all things groulng.

\section{Dese Bentifuz.}

Her (NIght's) I1p are still - for she hath heard God's roloe that wores the undrerse.

\section{Alabt.}

God mores with thee: we neen to hear Hig feet, Wnd-11ke, alopg the Iloora of heaven beat.

\section{Di senohentuent of Deathe}

Hualat She if doad - . -

of earth she is now -..-

The winds of epring that whisper to the grass Shall hint of hor: and she herself shall pass Llke prayer. Into each flewer wh memoxy crowned.

\section{Adonas.}

He is made one with nature. There 18 heard Hi. roloe in all her musto from the moan of thunder to the song of night's sweet blrd. 
The seft sky and 208, the low atnd whiopere near, Th: Adonals calls.

He is portion of the loveliness Whioh once he made so lorely. Sholley:

\section{Iintern Abber.}

(Ood) those dwolltac is the 2lght of setting suns, A motion and aplrit that impolo And 2021s throuch all thinga.

Wordsworth.

\section{Sonnat.}

Ilaten! the mighty Boing is arake And doth with His eternel motson make A sound like thunder- verlastingly. Wordeworth.

\section{Menfred.}

$$
\text { Oh, that I were }
$$

The Vlewless spirit of a lovely sound ........ born and dylng

Wh th the blest tone which made me. Byron.

\section{The Iroem.}


So cloudlese, olear and purely beautiful That God alone was to be seen in hearen. $\ldots \ldots \ldots$

Wh th the star:

And the quide Spirit of the Universe

He held his dialogues.

Byron.

\section{In yemortax.}

Thy rolce is on the rolling air.

I hear theo where the waters run;

Thou standest in the rising sun

And in the setting thou are falr.

Though mixed with God and Nature thou

I seem to lore thes more and more.

Tennyson.

\section{The Viaton of sin.}

And on the glimmering limt far whdraw

God made Himself an awful rose of dawn. Tennyson.

\section{Paracelaus.}

(God)

From whom all beling emanates, all power

Proceeds; In whom 1 s 11 fe forevermore;

Yet whom existence in 1ta lowest form

Includes.

Thue he dwelle in a.1.

9. 
Irom 21fo's minute beginninge, up at last

To man.

Browning.

Saul.

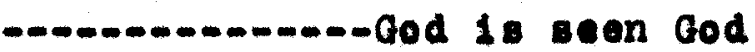

In the star, in the stone, in the rleah,

in the soul and the olod. Broming. 
(3) HIS POETRY TBACHES BVOLUTIOI OF THR SOUL.

Cawein has embedied in sons what other poet have done before. that is the theory of the erolution of the soul whioh selzes the apiritual side of the scientific fact and fusea it with imagination.

In his "Preface to the Iyrical Ballads" Wordsworth says. "Poetry 18 the beeath and flner oplast of all knowledge; 1t Is the impassioned expression mich is in the countenance of all science. If the time should ever come when what is now called solence shall be ready to put on a form of flesh and bleod, the poet wi2l lend his distas oplats to aid the transfiguration.

It hes been ominounly foreboded that in this beldiy practioal oge the poet would come singthg of science;" but Cawein's thought is sugpliced wh beauty and cherre, and the solentsfle truth, esen through the lens of the poet's Imagination, takes on a hale of 11ght.

The following linos present erolutson:

\section{Dedty.}

Thus I ditine him: Whon the soul refined

Through lore and widom through a thousend years.

Shall mount os pure intelligenos and pleree

The separate oyoles singing unto God.

Theis iftdepcent erolutiona arbed

* (Foot note) The Hermetso Ph110sophy of tho enciont IIgyptians treats of the nature of cod and the soul, and pretends to selto and explain all the pronomena of nature on a seientific basis. 
$-{ }_{-}-$- $^{-}-$- $^{-}-$- it shall see

Resplendencles of empyrean light.

Intimations of the Beautiful.

Should man,

All ignorant of heavenly ends,

Desplse the means, since earth began

God works by to perfect His plan,

Which through immediate forms ascends

Of Nature lifting, race by race,

Man to the beauty of his face?

Intimations of the Beautiful.

As Nature in herself resolves

All parts of beauty to one whole,

And from the perfect whole evolves

The high ideals that control

Advancement, till the time be ripe

To doff disguise and, type by type,

Reveal the emanated soul.

The Excursion.

- - . - - - our blooming girl

Caught in the gripe of death and was conveyed

From us to inaccessible worlds, to regions

Where height, or depth, admits not the approach

of living man.

Wordsworth. 
Tennyson expresses the theory of evolution in these words from his poom, "Maud":

"So many a million of ages have gone to the making of man: He now is first, but is he the last? Is he not too base?"

\section{Iocksley Hall Sixty Years After.}

Many an aeon moulded earth before her highest, man, was born,

Many an aeon too may pass when earth is manless and Tennyson. forlorn.

-..-------

In Browing also we find the same doctrine. Paracelsus. ....................... So in man's self arise August anticipations, symbols, types, of a dim splendor ever on before In that eternal circle liffe pursues.

\section{Fvelyn Hope.}

I claim you still, for my om love's sake! Delayed it may be for more liver yet, Through worlds I shall traverse, not a few: Much is to learn, much to forget Fre the time be come for taking you. Browning.

\section{Paracelsus.}

Are strewn confusedly everywhere about The inferior natures, and all lead up higher 
All shape out dimly the supordor race

And Man appears at last.

Browning.

* (Foot note)

Bdith momas, an Amerioan poet, presents the doctrine of erolution in the following 21nes:

"In the fold of His garment I slopt, without motion, or knowledge, or ak111.

While age upon age the thought of creation took shape at HLs will. 


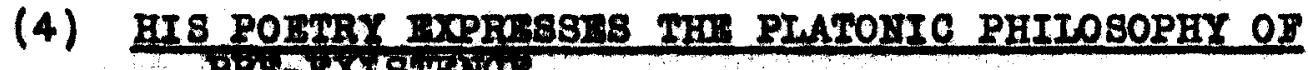

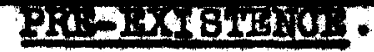

Plato's idea of pre-exditanoe, or the extistence of the sous before its union with the body, has entered into the popular creeds of many nations and to known in olassio Greek Iiterature as the Platonlo phllosophy, which ales teaches that the soul asconda from the lore of the beautiful many to the love of absolute beauty. Cawoin expressen this idea of preextstence;also Wordsworith, Shelley, Tennyson, and Browning in the selections which follow:

\section{Intimations of the Beautiful.}

No thing occult of hoaron or earth.

Or influenos of such; I Ieed.

But hath meaning and worth

God, In HI a modom, doth oonceal:

Reflections of another birth;

- Fxistent with and kin to ours.

The remint boencer that name.

romentwe through the and of man.

Of thisg: hip nemers can not name,

Iost things hls knowledge can not sean, -

Hinte of past periods are not these,

His soul hath IIred sinee it had birth

In God.

What far, acolian echoes lead

Ly longthg?

What onoes, blowa from lands that 110 
Molodsous 'neath no wertal oky?

Wordaverth' philosophy differs somowhet from Plato's in holding the nom-born soul nearer to ood and truth than the aged philgsopher.

\section{Ode on the Intimatione of Immortality.}

our birth is but aleop and a forgetting:

The soul that rises with us our, 11fe's star.

Hath elsowhore had its setting,

And cometh from afar.

Hot in ontire forgetfulness.

And not in utter nakedness

But tralling olouds of glory do we come

Irom God, who is our home.

Wordenerth.

\section{The Manntetn Boha.}

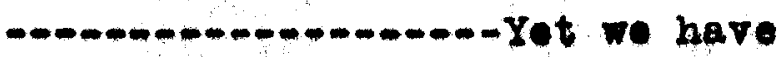

Aspwers, and we know not whepce;

Hehetefrom beyand the exaye

Rpoogntsod tnted148anoo.

Wordeworth.

\section{Ensorghidion.}

And erery motion, odor, beam, and tone

With that deop music is in unison:

Whion 1s a gol within the soul, - they seam

Iike ochoes of an antenatal dream. 


\section{The Tue Tolen.}

Uoreaver, somothtus ts or seoms,

That touohes mo with myrtis gieams,

Ilke glippaes of forgotton dreams.

Tonnywen.

Browntigts dedfeatton to 4ro. Browning after hor death of "The RAng and the Book" aoknowledges the ldealistie be2iof of pro-oxiotonoes

" 2 yele Love, half angel and half bird, Whan the firot oumbois fros the darkilng earth Reached thee and tholy chambers, blanched their blue, And bared them of the glory - to drop down, To to12 for man, to ourfer, and to die." 


\section{(5) HIS POBTRY BXPREASRS A BRTIRT IN THE IUNORTALITY OP TWE SOUL.}

Carein's pootry expresees firm bellef in the immortalIty of the soul, and his verses elorify the oternal daw as the great sages and poete have done from Plato, Mliton, Shakespeare, and Goothe down to the present day. The spiritual light of imortality burste through Cawain's poen. "The Intimations of the Beautiful" from which these lines are. taken:

"Suffiolont for my fasth is suah:

Thet. in the parrem nicht that binds

The seed, it ilfo hall ferl in touoh

Wi th light abore it seaks and finds.

Behind all death purpose stende

Wi th hallowed and magnotse hande

Beneficent and strong to hoal."

\section{Iopenthe.}

A living gloxy ia the tomb, Whose night shall and in Iight: An intense oplender veliod with eloom. Too blinding for earth!s sight.

\section{Won.}

Sweet is the rolee bohind we

of 2150 that foldeweth;

And awaet the roloe before no 
Of 11 fe whose name is Death.

A Sleet-storm in Kay.

Alas I lad heart, break not beneath the pain!

Time ohangeth all; the Beautiful wakes again.

Cawein accepte immortality as a fact, but Broming In the poem, "Is Salataz, tries to prove the smmortality of the soul in an argument botreen Panoy and Reeson, but leaves it an unproved hypothesis.

Fanoy thrusts and Reason parries.

\section{Fenoy.}

Iffe has worth incalculable, every moment that man apends

So muoh gain or $108 \mathrm{~s}$ for that next 11fe, which on this 2ife depends.

\section{Reason.}

-.................- Certainly as God exists,

As He made man's soul, as soul is quenchless by the deathly mists. Browning.

\section{Sant.}

By the pain-throb, triumphantly wianing intenBlfied blis8.

And the next world's rewpre and repose, by the atruggles in this. Broming.

\section{Peuline.}

Sun-treader, I bolieve in God and truth And 10re. 


\section{(117e thou on forever.}

- And be to axl what thou has been to nel

Browning.

Worderorth's famour "Ode" breathes of the Intimatione of imortality.

$$
\begin{gathered}
\text { (The ohild) "Thou, over whom thy imortality } \\
\text { Breode like the day." }
\end{gathered}
$$

\section{Erening Veluntary.}

Yy coul, though yet confined to carth.

Rejolees in a second blrth.

Wordeworth.

IInes from Dhelley and rennyzin euggest the same bellef In the immortal soul.

Inoterohidion.

For in the rielde of imortality

uy opifit should at flrst have worshipped thine. shelley.

\section{On Death.}

o yant bold thee on in courage of souz. And the billows of oloud that around theo roll Shall sleep in the 118ht of a wondrous dey. Bhelley.

\section{In Lemeriem.}

How pure at heart and sound in head,

Wh th what divine affection beld

Should be the man whose thought would hold

An houx's communion with the dead. 


\section{Vestness.}

Peace, let it bel for I loved htm and love him forever: The dead are not dead but allve. Tonnyon.

St. Stmeon stylites.

Courage St. Simeonl This dull chrysalis

Cracks into shining wings, and hope ore death

Spreads more and more and more.

Tennyison. 
(6) CALRTH 18 POBTRX DORS MOT TREAT OF THR DOCTRINES Oy CHRISTIATILY.

In his collection of poom this poet makes very beaut1ful refarences to chrtat, but consldering nis poetry on the whole. we find that he has not incorporated any of the doctrines of revealed religton; but wo may belleve 21ke Hatther Arnold that the "eweet roasonableness" of Chrigtian1ty appealed to the heart and the alnd of the poet.

In this he is agaln like shelley, who in a rerorential tone refors to Jesue as one of gent2e worth in "Promothous Unbound."

Broming, as we all know, 1: the ohomplon of Chrietianity and the Apostze of Christ in pootry.

H2. poen "A Doeth in the Desert" is defence of the Christian fatth, while "The Azab Physiolan" and "Cloon" set forth the dootrine of the incarnation.

The followng passages are from Cawaln's pous, bearing referenoe to Christ.

\section{yearage of the Itilde.}

We are His 21110s, 211108,

Whose praises hore we singl

We ere the 211108, 211108

of Ohriat our Lord and Kint.

\section{A Legend of the Illy.}

And a flower arose on the mound of green,

White as the rebe of the Nazarone:

To testify of the iffe unseen. 
$-\infty-\infty-\infty-\infty-\infty-\infty-\infty-\infty-A$ nd nlght

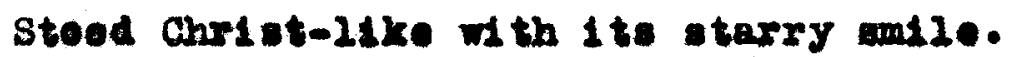




\section{COYCLUBIOL.}

In conolueton we may define the religton and phllosophy oxpressed in Cawoin's poetry as ideeliatic and pantheletie, with a prefound workinip of the batty and a deep pasalon, potent with a belief in a 21fe beyond the grare, whose rell of darkness his oubtilized epirit seems to ponetrate.

He i. Itke Plate in his phlzesephy. Wordaworth in his 1dealian, Shelley in his panthelan, and 11ke Broming in his otrong and ferrent fal th in God. 
2.

CATISIN'S

POETRY MOR CHITDRIA. 


\section{CATEIXIS ROBTRY WOR OHILDRETI.}

In appealing to the poetse instinet of the child, let us examine carefully Cawein's poems and compare them with those of other poeta, who have written verses for children, viz.. Wordsworth, Blake, Mrs. Browning, Sterenson, Bugene Field, and James unitcomb Riley.

The phases of $21 k 0 n e s s$ and difference whioh we shall find are as follows:

\section{Phasen of Itkonene.}

- 1. Cawedn Assoolater Hature and Onlldhood.

2. Cawain Appealp to the Imagination.

3. Cawein Does yot Point out the loral Hement.

\section{Phasen of Differenon.}

1. H1. Poralstent Porgoniflcation of Nature and Abstraot Ideap.

2. His Introduction of Mythologt oal Charaoters.

How let us proseed to verify these statements, considering each separately. 


\section{PIRST PHASR OF ITETHRSS.}

(1) Cerreln Assooiater Iature and Childbood.

Carresn roxy intimately assoolates the ondid with the vartoue formis of llature, and he has the glft of touahing the commonest thing in lature and malding it 117 as a part of the ohtld's 11fe, this onxlohtag his oxpordence and layt ng the foundation of charaoter.

His nature poens that 2 ure the ohI2d inte the fleyd and forest are great force for the development of his apprealation of beauty, and they form a I1nk of eympethy between him and the 20war strata of 2150 and araken a kindred foeling for all oreatures of the woods and fields,

"The Twilight Noth,"

"The Tree Toad."

"The Ieat corloket."

"This Blue Bird,"

"The 0wlet,"

are poetsfipd with tender seeling and 20re. What can be more appealing to o chlld than the baby orlet's ory?

"Thon from the hills there comes a cry. The orlet's ory:

A bibtrering roioe that sobs and soreams

with terror screame :-

Who it 1t, who is it, who-0-0-?

wo rides through the dusk and the dew,

Wh thalr of horns

As thin as thorns

And a faoe bubble-blue? 
Who, Who, Whol

Who 10 1t. who is 1t, momo-0?"

"Dumpy toadsteols, grom alose by

Our $2 d$ peach treo," (Toadatoole)

"And I am going to laugh and run

And be the comrade of the sun."

(Sun and nowers)

Here we find Cawatn dealdng wt th some of the simplest forme of Iife and in thi way enlarging the mind's capability appreosatien.

In hlo proface to the "Iyrical Ballade" Wordsworth says. "The human mind is capable of belng exolted without the application of gross and violent stimulants ........ and ono being 18 elerated above another in proportion as he possesses this oapablilty. ... To ondeavor to produse or enlares thls capability is one of the boot services in which a writer oan be engaged ."

How let us see how Wordswerth assoolates Nature and chlldhood. In the "Kitten and Falling Leares" the poet abandons indmels to the oplrit of playfulness and the child onjoys the aport.

"That way 100k, my infant, 101

What arotty baby showl

\$ee the kitten on the wall

sportsing with the leaves that fall." 
In the bazlad of "Iuey aray the ohtzd is associated with the snowstorm and the lonesome wid.

"And you may see sweot Imey oray

Upon the lonesome wild."

WIIIam Blake, the Celtio poot, in his "Bongs of Innoconce" writse of pastoral soenes, the shopherd, the little lamb, thus arakonlag the ohild's smapathy for all God's oreatures. This poet palnte from real $11 f 0$, just as he finds 1 t. The Letile Lamb.

Ittle lamb, who made thea?

Dost thou know who made thee?

Chre thee 21 fe and bid thee feed

By the stream and oe'r the mead

Gave thee clothlac of delight

Softest olothing, woody bright:

Gave thee suob a tender rolee

Jaking ald the rales rejolee.

IxttIo lamb, who made thee?

Dost thou know who made thesp

H1 sabeth Barret Browning associates the child and wth the pine trees, earth and sky.

\section{A Childis Thought of Ged.}

They an that cod I1res very high;

But If you look abore the pinas,

You can not see our God and why? 
Robert Iouls Steroneon often takes the natural environment of the child and weares his rerses for ohlldhood of birdies and thoir eggs, the friendiy cow, "Rain," "The WInd," "Neat Rggs," "The Howers," to.

\section{The Cor.}

The friendly oow all red and white.

I love with all my heart:

She gires the oream wh th all her wight

To eat with applo talt.

\section{Ine to Btre.}

A blrdse wh th yellow blll

Hogped upon the window a121.

Coaked his shining eye and said:

"Asn't you' shamed, you sleopgrhead.

Bugene Fleld lote the chlld browse in olover bloom,

11. under the blossondng applogtree of gambol wh the flowers. Butteroun, Poppr Dozrat-me-net.

Butteroup gambolled all day long.

Shariag the 2ittle child's wirth and song;

Thon stealing along on misty gleams

Poppy oame beartag the swootest dreams.

And we found betsman in a hollowed spot

The solace and peace of Forget-memnot. 
Razey's "Ilttle Red Apple Troe" 1 s typioal of his assoosatsing Neture and chlidbeod.

"The 11ttle red apple treel

0 the 21 tite red apple treel

Whon I was the 21ttlo-ost bit of a boy. And you vere a boy wh me.

Riley.

Thus wo woe that Cawein bringe rature into the chlld's being as other poots do, utilising it for his ploture as a sett1ng. whs oh the ohlid ingtantly recognizes as a part of ht awn expartenoe. 
BRCOND PHAST OF IILCEITESS.

(2) Garatn Annere in the rmagination.

In all of his peonn Carreln eppeals to the "eacrod spirit of wender" an Carlyple saye and the poet's overflow of soul widens the Intelleotunl perception, enriohen the imagination, and unfelds the opiritual life of the ohild.

This wetter feels the sacredness of ohlldhood, which is entrusted to his care, and whiah Wordewer th feels whon ho saym,

"Not in entire forgetfulness. And not in utter nakedness, But trailing oloude of gloxy de we come From God who is our hame. Hearen 210 about us in our infanoy." (ade on Intimationn of Imortality.)

In manj of cawaln's poens wo find falries, glants, witchea gnomes, pixtes, alves, and the deor of fairy land ia unlooked by his creatite gentue and the chlld's mind teens with phantams of the Lmagination. "The Faery Ring," "Feory Child," "Giant and the Star." "The Ghost," "There are Feories," "Iand of Candy" all appeal strongly to the imaginative faculty of the reader.

"The Beery Ring" is a desoription of the dance of the falrios at midnight.

"And round the toadstools, white as milx, They danced with fly he looks. Thefr trousers made of moon-flower silk, Thels gown of four-o-0locks. 
"A oxtekes plped, a frog drumed near In plxy minstralay. And round and round in moonilight clear They 2od thelr retelry.

"Until far off I hoard a cook Grot and the elves were gens. Inarling those teadstools by the rock For un to see at dam."

\section{There are Fatrits:}

thore are falfles, bricht, of oye, the the widflower's warders ara. Ouphes, that chase the firefly. Ifvea, that 7 de the shooting-star: Tays, who in a cobrob 24 . suffneting on a moonboam bar.

The onsld's eyo open in wonderment at the Giant who blew/out the otar and deveurad the wanderers that lost thedr way.

\section{Qiant and the Btar.}

"I 71 juet blow 1 t out," he sald, And heared up his bulky bones. And went grumbilng up the stones

To the rery mountasn's head; Shaking with hie mighty tread 
All the orege and plnes around

And bagan to blew and blow.

TL11 at last, 10\%, so 10\%,

Dullex grew that star's bright glow.

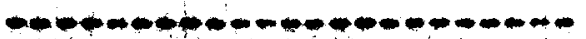

Saytas "This will be 1 to death."

pulged his ohooks and blem at 16 .

Blew and blew and neter quit

Till the otas was blown quite out."

\section{Inge ef cendr.}

Mixet place that they came te, why.

Was a woed that reachod the aky:

Poreat of atiok oandy. Hyl

In these poens we see hew the child's unfettered imagInation soara with a free wing srom the little green frog that drume in plas manotrelay to the elfin fairses of the moon. Cawedn is perelotont and derindte in his appeal to the imaginatyo inpulees, and the stimulue is healtheul end conduodve to the ertowth of the wind.

Wordaworth belng a poot-phl10aopher throwe the glomour of h1/s Imagitiats on orer expextences "whereby ordinary thinge shoupd be prosented to the atind in on unusual aspeot." Thus the "dancting daffodsig" and "danetrg iearas" are part of the ohl1d's orery day 14fo.

\section{The Daferd13.}

I san a orowd, 
Beslde the Inke beneath the trees

Flutterkng and danalng in the breese. Wordsworth.

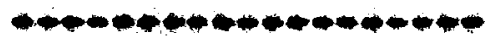

De orene Itunt.

My dassied atcht ho oft daefres,

arethor of the danelag 1nares.

Wordinwerth.

\section{(Blave)}

The Imaginattre fores of Blakel "Bange of Innooence"

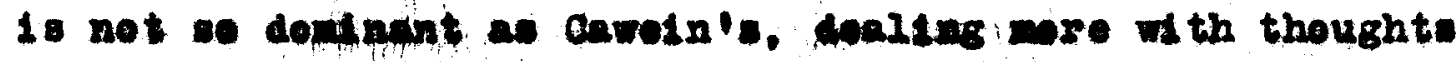
within tho obild's oxport oned and only occastonally sailing through the realin of Imagination, as la erident in the following lines:
"Plpling down the ralleyd wid. Plpling sengs of pleasart gles. In a cloud I waw a chlid And he laughing sald' to wo."

H1 sabeth Barret Browning, knowing by payohle analyols the questlonings of a chlld' mind, and serealsag the mystory whioh enehrouds his belng, presonte these 11nes, whlch, whe thinks, wow how the innocent atind Imagines god.

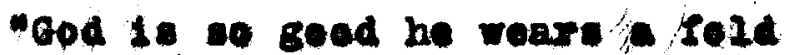

of hoavon and carth acrobe his face."

(A culld'e moluent of dod."

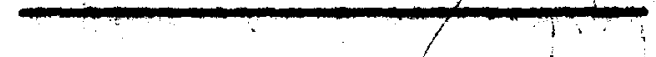

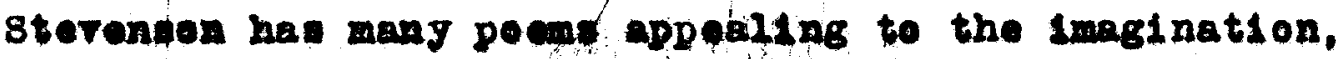
"Pairy Bread." "Isad of Counterpeng." "yy Bed 1 a a Boat" oto.
} 


\section{Ind of Countersane.}

I was the glant great and stdil

That aits upon the p1210w hill.

And sees before him, dele and plasn.

The pleasant land of counterpane.

Some of Hugene II eld' imaginative poems are "Wynken, Blymken, and Hot," "Soeing Things at Night," and "The Duex," between the gingham $d 08$ and the caltoe cat.

Ereken. Blymken and Iod.

Wynken, Blyken, and Iod one night

Salled off in a wooden shoe.-

Salled on a river of orystal light.

Into sea of dow.

The ld moon laughed and sang a song.

As they rooked in the wooden shoe

And the wind that oped them all night long

Ruffled the wares of dew.

Riley' "IIttle Oxphant Annie" is well-known to all ohlidren who read verse:

"And the goblins 111 ast you

Bf you don't watioh out.".

Having compered the imaginatire poeme of these writere we may now state that Cawein appeals strongly, definite1y, and more persigtently to the Imagination than Wordswerth, 
Hrs. Browning, Blake, Bteronoen, Mield, and Rlley.

Wordewarth throwe the chere of Imagination orer rrature as one entere Into his dally 11fe; Blake has hore and there a felry or pixy; ure. Broming has only one poem whioh ohe matakingly thought was written in ahild language. "A Child's Thought of God," which avakens the imaginative impulse; and Sterenoon, Meld, and Riley stimulate the imagination of the child but not with the same degree of peralstenoe as Caweln. 


\section{THIRD PHAST OF LTKGIIESS.}

(3) Garetn Don not Rotat eut the Yorel Finent.

Madisen Cewosn is no houl 2etle Blnger, obtrudsng a moral.

The religtous motsl does not enter into hil poetry for ohildren, and nover does he put on the heary weights of moral teaching or didactiolum. In this respect he is like the other poots consldered in thlo thosis excepting wizliam Blake and our staunoh friend, wi2liam Wordewerth, who saye:

"ibrery great poet is a teacher; and I wh to be considered as a toacher ox as nothing. To consele the afflioted; to add sunmine to daylight by making the happy happlex; to teach the young and gxactous of erery age to see, thlnk, and foez, and olncerely v1rtuous -......."

that was his rosatson; to Bhow that the mutual adaptation of the external world and the inner mind 18 able to ahape a paradise from the "almple produce of the common day" - that was his high argument.

"Luey Gray" and "Wo Are Soren" are philosephlcal poems. the first teaching the opiritualieation of character, and the socond that a little child knows nothing of death. One of the most striking characteristion in Blake's sonce for children is his element of falth in God. "Iftle boy lost in a lonely fon

Led by wandering light

Began to ory; but, God ever nigh 
"Appeared like his father in white."

$$
\longrightarrow
$$




\section{PHASB OF DTWLRETCE.}

The phases of differenoe between cawoln and Wordsworth, Blake, Hrs. Browning, Stevenson, Field, and RIley to be discussed are:

1. Cawe1n' Persistent Personffication of Nature and Abstraot Ideas.

2. His Introduction of Mythological Charectera. 


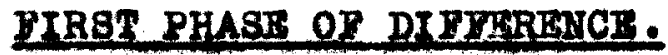

\section{(1) Cawetalg Pergtetent Personification of Nature and Abstract raese.}

The most otriking differenee between Ladison Cawein and these poets is his persistent personification of Nature and abstract 1deas, endowing then wh human ettributes, thus bringing them nearer to the heart of us.

Wile the poets under consideration evinoe this characteristio, each in his own degree, yet they do not possess it to the unlinited extent as our Kentuoky poet. The following quotations personify Nature:

"The lorning drew shawl of misty 1000 around her."

(Morning Road)

"Pale as a ghostly otrl

Lost 'mid the trees, - looks dom the moon

Wh th face of posxl."

(Morning Road)

"The young-eyed Dusk comes slorly down

Her epron filled wh thers." (At Sunset)

"But oll night 10ng.

Wingting its hands, I hoard it wall 1 ts 2070

Unte the Moon."

(Thi Gray wood)

"Slipping ringe of marlgelde on her chllly ingere, Blinding her gipey looks with gems." (Autumn) 
"Th1s is the tombey month of all the year, Maroh who comos .............

a wadlowor in hor cax," (uarah)

The poot personifies abstract ideas in the next fer Ines:

"One stood quits young and fatr. Peace, with the golden hals. -........ guarding constantly

Hor babe, named song." (Morning Road)

"She site among the sunset bi21s, or tradls a aluken skirt of breeze.

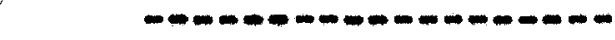

She reste upon a l1chened stone, Her moonbeam hat: upread bright around." (wh tohery)

Fosdaworth.

To quote Ixom "Iyxical Bellade" Wordsworth saya, "The

Reader wil find that personifications of abatract ldeas rarely occur in these relumen, and are utteriy rajected as in ordinary derice to elevate the style and raine it ebove prose."

Hence we do not find abstratt ldean or Nature personified for the ch12d, but we do find these porsonifioatioks in his poems of doeper thought.

Ode to Dutx.

Stern Daughter of the Votor of Godl 
0 Dutyl

Stern Lawgiverl yot thou cost woar

The Godhead's most bendgnant grace. Wordaworth.

\section{Ode Immartality.}

Tre moon doth with delight

Look wound her when the hearens are bare. Wordworth.

Blake does not use personiflcetion often but the "Laughing Bong" it a geod speotmont.

"When the green woods laugh with the rolce of joy. And the dimpling otream runs laughing by: When the moadows laugh wh th lively groen, And the grasenopper laughs in the merry soone."

Mrs. Browing dees not use personification for children but we often find it in hor "Bonnets from the Portugese" Into which the has poured the full flood of her profoundest thought with exquilat teneas.

\section{Sonnet.}

When some belored rolos that was to you

Both sound and ometnong falleth ouddengy And silenee agalnst whit oh you dare not ory Achpe round you like a strong disease and new. What hope? 
Sterensen frequentiy persontfi os sun, moon, stars, blrds, eto., but not soportediy and uncenalngly as Cawoin.

"Late lles the wintry oun a-bed.

A Erosty flexy sleopy-head;

Blinke but an hous or two: and then

A blood-red orange, sete again."

(Wintry Itwe)

Again we ofton find it a forceful faoter in some of the poeme of Field and RIley.

"And the nicht would oay in 1te ghostly way:

Yo00090 ."

(isteld's "The Night Wind").

"The sum burst forth in giee, -

And wom that bluebird ang, my heart

Hopped out of bed wh thef"

(Rtley' "Flrat Bluabdrd").

Judging from the foregoing date our deduction is that

Cawein clinge teneclousiy to the figure of persontfication, and wh th a greater degreo of paraistenoy than the other poets, which makes hig poetry stronger, more virid in imagery, and more powarful in ewakening the doep foeling of kinghlp botween the child and the created undrerse for

"The meaneat flower that blow can give Thoughts that do often 2Le too deep for tears." 


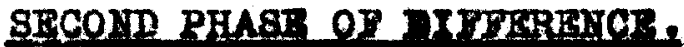

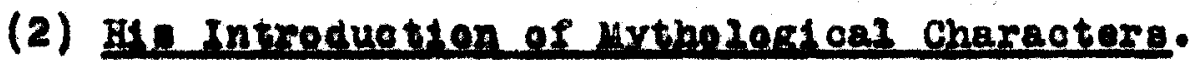

Another otriksing difforenes, whioh otands, out in altoreliero, between Caweln and the other poots is his constant alLugion to mythological characters or forms, the nymph, dryad, faun, Pan, Pandora, and Kercury; and these are especially good for drometization, familiariatng ohildron with the Greak 02088100, and cultivating a taste for Hellentc Iiterature.

In b1s love fer the Greek Cawain is I1ke Keats, whose poetry is nearor the Groek than any other Inglioh poot.

of gourse those poens exeating mythio Itgures are addressed to elder chlldren who would no doubt go athirst for higher knowledge concerning the feip loles of Groece.

In this phase of his work cawein is agaln persistont and the following quotations show thie unique cheracteristio: "a toad hopped out.

Croaked, and cropt Pan's foet about." (Pan of the Beoch Woods).

"I saw the Dryads stt at ease Within the hiding heerts of trees; And in bramblea, wetching these The Faun that none hath sound." (Faexy Porest).

Nof falx Pandore and hor box, of old You've heard parhaps. ....... And it was Maroury 
"The ounnting meseenger of the gods."

(Pandere' Box). 


\section{conolusion.}

Hardag compared cawadn's juronize pootry with that of other poets, we have alearly proved that ho stand in high rank among tham, by dereloping in the chlld a sympathy with Neture, thereby mouldsng his character and arakensing spiritual dam, by appoaling to the imagination and endowing it with a wealth of beauty. by widening his intellootual peroeptions and fliling him wh th deep love for the Bplat of the Univorse. 
THE HUNAN BILEMEAT OF MADISON CAWIIN'S POETRY.

Wo shall now consider cawein's peetry under the following topics:

I. His Human Poetry Includes an Expression of Love, Hatred, Despair, Kelancholia, Hope, Faith, Pride, Joalousy, and Joy. Hi a Poetry Shows Also an Interest in Science, Music and Art.

II. His Poetry Shows Interest in the Following phases of Iffe: The Humble, Mountain and Feud IIfe, The Gipsy Iifo, The Slums, The Vampire, The Indian, The iregro, The Charcoal-kan, The Miser, The Child Iffe, and Historic Periods.

III .Fuman Poetry of Wordsworth, Tennyson, Shelley and Browning.

IV. Cawein as Compared with these Poets. 


\section{$\underline{\underline{I}} \underline{\mathrm{V}} \underline{\mathrm{E}}$.}

Love is a predominant element in Cawein's poetry. Some of his lyrics have the spirit of true love in them and are fully charged with isolated emotion. They are beautiful with a beauty of their own, and full of that natural abandonment of the whole world for one moment with the women he loved, which youth and the hours of youth in manhood feel. The lyrical eclogue, "One Day and Another," is a conversation between two lovers whom death parta; but who recurrently find themselves and each other in the gardens and the woods, and on the waters. The effect is that which is truest to youth and love, for these transmutations of emotion form the disguise of gelf which makes passion tolerable.

She, all my heaven of silvery, numberless

Stars and its moon, shining golden and slumberless; Who on my life, that was thorny and lowery, Came and made beautiful; smiled and mado flowery. She, to my heart and my soul a divinity! She, who - I dreaned - seemed my spirit - affinity. (Ono Day and Another).

\section{Remembered.}

She was my all. I loved her as men love A high desire, religion, an ideal, The meaning purpose in the $108 \mathrm{~s}$ whereof God shall alone reveal. 


\section{Heart of My Heart.}

Stars are not truer than your: soul is true;

What need I more of heaven then than you?

Flowers are not sweeter than your foce is sweet-

What need I more to make my world cormplete?

Heart of my heart.

\section{Words.}

Look in my eyes: read there confession:

The truest love hath least of art:

Nor needs it words for its expression

When soul speaks soul and heart speaks heart.

\section{To Gertrude.}

These are flowers I bring to thee,

Heart's ease, euphrasy and rue,

Grown in my garden of poetry.

Wear them, aweet, on thy breast for me:

The first for thoughts; and the other two

For spiritual vision, that's always true,

So thou with thy soul mayst ever see

The love in my heart I keep for thee.

Browning's poem, "By the Fireside" is a tribute to his wife whom he loved with all his soul, and he recalls the moment of early pasion while yet they looked on one another and felt their souls embrace before they spoke. 
Think, when our one soul understands

The great word whlch makes all things now,

When earth breaks up and heaven expands,

How will the change strike me and you

In the house not made with hands.

So grew my ow small life complete, As nature obtained her best of me One born to love you, sweet.

Note Browning's intensity in his love which made him stand and withstend in the battle of life, ever a fighter to the close.

\section{Prospice.}

I wa ever a fighter, so-one fight more,

The best and the last 1

I would hate that Death bandaged my eyes, and forebore, And bade me creep past.

And the elements' rage, the fiend-voices that rave Shall dwindle, shall blend

Shall change, shall become firot a peace out of pain, Then a light, then thy breast,

O thou soul of my soull I shall clasp thee again, And with God be the rest!

This love made Broming the strong man he wa; the fire caught and purified the passion of his soul. 
Shelley, though intense in his love, is idealistic, and the weight of thought and feeling burdened him heavily. You read his sufferings in his attenuated frame, while you perceive the mastery he held orer them in his animated countenance and brilliant eyes. Foipsychidion is an expression of abstract boauty and is his conception of ideal love.

I love thee; yes I foel

That on the fountaln of my heart a seal Is set, to keep its waters pure and bright

For thee, since in those tears thou has delight.

Beloved, 0 too soon adored by me 1

For in the fields of immortality

My spirit should at first have worshipped thine.

$* * * * * * * * * * * *$

\section{To Mary Shedlex.}

As sunset to the spher'ed moon,

As twilight to the western star,

Thou, belored, art to me.

草前*********

Byron's love was a variable quantity, inconstant, and vacillating, judging from his lines

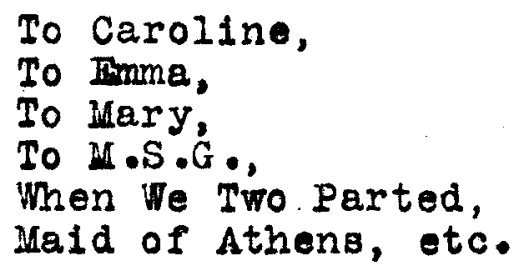

Byron's women are mostly in love with Byron under various names, and ho rarely strays beyond the woman who is loved or in love. The following examples set Byron's standard of love 
Which we shall soe is not very high:

\section{To M.S.G.}

Whene'er I viow those lips of thine,

Their hue invites my forvent kiss:

Yet, I forego that bllss divino,

Alas! it were unhallowed bliss.

$* * * * * * * * * * *$

To Mary on receiving her pleture is of a little higher order and we all know the pretty little lyric, Laid of Athens.

\section{To Mary.}

Thoaugh hours, through years, through time 'twill

cheer:

Wy hope in gloomy moments raise;

In life's last conflict 'twill appear,

And meet my fond expiring gaze.

\section{To caroline.}

Again, thou best belored, adieub

Ah, if thou canst overcome regret,

Nor let thy mind past joys review,-

our only hope is to forget.

$* * * * * * * * * * * * *$ 


\section{프 $\underline{A} \underline{\underline{\underline{R}}} \underline{\underline{\mathrm{E}}} \underline{\mathrm{D}}$}

The romance, Accolon of Gaul, reveals the bitter hatred of horgan Le lay for her brother, King Arthur, and her husband, Urience. She pauses with uplifted dagger before she slays her husband and says:-

"Nay, Nayl too long hast thou livedd

- - - - My sorrowl who for years

Hast leashed my life to thine, a bond of tears,

A weight of care, a knot that thus I part!

Into the naked elements."

For her haif-brother Morgan had conceived

Unnatural hatred; so much so, she grieved,

Envious and jealous.

$* * * * * * * * * * * * *$

"Masks," from the setting no doubt a story of Venice, portrays the hatred and revengo of Gaston and Viola, the woman scorned by Balka, a monk, who is masked to meet Blora, the Count's daughter. Viola promises to marry Gaston if he will murder Balka and Flora. Gaston speaks: "I saw him

Stalking towards the church: around it

Dogged him, marking how ho smiled

In the moonlight where he waited

.......... Hi form bejeweled

Gleamed. My very blood burned dry

With the hate his presence fueled.

$* * * * * * * * * * * * * * *$

Our revengel up-pushing slightly

Cowl, the mask fell and revealed 
Balka, as the poniard whitely

Flashed. The hollow nave re-pealed

One long shriok the loft repeated.

Swift, I stabbed her thrice. She reeled

Dead. . . . . . . . . . . -

on her face the mask hung, married

To 1to camphor palior: wide

Eyes with terror." 


\section{D $\underline{\underline{S}} \underline{\underline{P}} \underline{\mathrm{A}} \underline{\mathrm{R}}$.}

Despair through which faith finally gleams is the central therne of "The Glow-worm."

And thinking of one whom my heart had held dear,

Iike terrible waters, a gathering fear

Came stealing upon me with all the distress

of $108 \mathrm{~s}$ and of yearning and powerlessness.

(Then suddenly foll)

My soul to abysses of nothingness where

All light was a shadow, all hope, a despair.

Finally he beheld at his feet

-

An ember; a sparkle of dew and of glower;

Iike the lamp that a spirit hands under a flower.

And hushed was my soul with the lesson of light

That God had revealed to me there in the night.

Though mortal its structure, material its form,

The spiritual message of worm unto worm.

$* * * * * * * * * *$

\section{Out of the Depths.}

Let me forget her, Godl

Her who made honeyed lore a bitter rod

To scourge my heart with, barren with despair;

To tear my soul with, sick with vain desirel Oh, hear my prayer! 
Out of the hell of love's inquenchable fire

I cry to thee, with face against the sod,

Let me forget her, Godl 


\section{$\underline{\underline{Z}} \underline{\mathrm{L}} \perp \underline{\mathrm{N}} \underline{\mathrm{C}} \underline{\mathrm{O}} \mathrm{I} \underline{\mathrm{I}} \mathrm{A}$.}

Caweln has a poem, "Kelancholia", which somewhat resembles the mad-scene in Tennyson's Maud. One of the most famous physicians for the insane said of the mad-scene fn Maud that it was the most faithful representation of madness since Shakespeare. Maud is not a treatise on inganity any more than Caweln's poem is a treatise on melancholia, yet both writers show that these diseaser, which so often baffle scionce, have a side of feeling which they interpret in their poetry.

\section{Melancholia.}

Then suddenly - gorhaps it was the strain

Snapped in my temples - laughter seemed to twist, With evil, night's dead mouth that bent to mine and kissed.

Insanity! two leaves that dabbled down,

Touchod me with drizzle; and that laugh - ah well,

No laugh an owlet hodting at the frown

Night's hag face tortures while she works her spell

And I stood stark among the soddon stones,

Icy with fever, hearing in each gale

Strange footsteps... - . - . -

Then I remembered that within a tal.

Once I had read - how one shall not fail

To find unsought the Fiend.

Was that his laugh? and that his vulture hand?

Nol Nol for in the legend It was said,

"Though moonless midnight curse the barren land

Sathanas shadow follows him as red

As Hell's red cauldron is. 
And so she (melancholy) brought me to the river's brink To plunge me downward. All the night was mine; And so, exulting, to Death's darker dirink I stooped and drank. - What better drink divine, 0 man, hast thou? What wiser wey is thine? Who find'st me carrion on a hungry coast, Sand in mine ejeballs, in my hair the brine, And o'er my corpse with bitter lips dost boast "Poor fooll Foor ghostl Alasl poor melancholy ghost."

\section{$* * * * * * * * * * * * * * * * * *$}

\section{Maud.}

Dead, Iong dead, Iong dead 1

And my heart is a handful of cust, And the wheels go over my head, And my bones are shaken with pain For into $\theta$ shallow grave they are thrust.

0 me, why have they not buried me deep enough? Is it kind to have made me a grave so rough; We that wes never a quiet sleeper. I will cry to the steps above my head And somebody, surely, some kind heart will come To bury me, burs me Deeper, ever so little deeper. 


\section{$\underline{H} \underline{O} \underline{P} \underline{\underline{E}}$.}

\section{Intimations.}

The love and hope God grants me,

The beauty that lures me on,

Are but masks of an ancient sorrow

of a life long dead and gone.

\section{A Motive in Gold and Gray.}

How blessed is he who, gazing in the tomb, Can yet behold . . . . . . . -

Upon dead lips no dust of Love's dead bloom;

And in dead hands no shards of Faith's rent flask;

But Hope, who still stands at her starry task,

Weaving the web of promise on her loom!

The House of Fear is a symbolic drama in which Love, Hope, Fear, Sorrow, etc., are personified. Hope speaks to Man and in the halo of her brightness Despair and Sorrow disappear. (Hope): I am the last on whom thine eyes shall gaze;

\section{Immortal Hopel}

(Death slowly enters)

(Man): Light breaks around me and the winds of dam Sweep the wild mists of tempest far to sea. There is no darkness now, but rivered light Flowing from out the source of boundless day.

\section{Faith.}

The poet who can dream dreams of a purer and higher life and give beauty and power in expression of his faith in $-59-$ 
God renders divine service to mankind, and unnumbered miliions climb their way to Calvary with the poet's song in their hearts.

\section{Face to Face}

Deadl end all my heart's a cup

Hollowed for repentant tears,

Bitter in the bitter years

Slowly brinming up.

Peacel 'tis well b But might have been

Better. - Yes, God's time makes right!

Better for me in His sight

With my soul washed clean.

Peacel be still I kiss your hair. Sweet, good-by. Upon your breast

Let this long white lily. rest -

God will find it there.

There beyond the sal world and

Clouds and stars and silent skies,

Where your eyes shall meet His eyes,

There - He'll understand.

\section{Life.}

Behind all being a purpose lies,

Undeviating as God hath willed;

And he alone it is who dies

Who leaves that purpose unfulfilled.

Iife is an epic the Master sings 
Where each is a word in the Song of Things

That shall roll on while the ages roll.

$$
\text { Face } \frac{\text { Pride. }}{\text { to Face. }}
$$

Woman true, I falsely blamed;

Whom I killed with scorn and pride;

Woman pure, of whom I lied

With the nameless name.

\section{End of All.}

I do not love you now,

o narrow heart, that had no heights but pridel You, whom mine fed; to whom yours still denied Food when mine hungered; and of which love died I do not love you now. 
J $\underline{\underline{A}} \underline{\mathrm{L}} \underline{\mathrm{O}} \underline{\mathrm{U}} \underline{\mathrm{S}} \underline{\mathrm{Y}}$.

The Alcalde's daughter is jealous because her lover is going to moet the Lady Iona, and kills him with a daggor which she draws from her hair.

The Alcalde's Daughter.

The times they had kissed and parted

That night were over a score;

Each time that the cavalier started

Fach time she would swear him o'er.

Thou art going to Barcelonal

To make Naxera thy bridel

Seduce the Lady Ional

And thy lips have liedl have liod

And they kissed farewell: andihigher,

The moon made amber the. air;

And she drew for the traitor and liar,

A stiletto out of her hair. 


$$
\underline{\mathbf{J}} \underline{0} \underline{\mathbf{y}} .
$$

The feeling of joyousness and high-spiritedness is felt by the poet in the beauties of Nature.

$$
\text { Mood of the Farth. }
$$

My heart is high as the day is clear, As the wind in the wood that blows;

My heart is high with a mood that's cheer, And glows like a sun-blow rose.

\section{In Solitary Places.}

Up, my heart, and all thy hope put on;

Array thyself in splendor.

out, out, my heart, the world is white with spiring.

Iong have our dreams been pleaders. 


\section{$\underline{\mathrm{S}} \underline{\mathrm{I}} \underline{\mathrm{E}} \underline{\mathrm{N}} \underline{\mathrm{C}} \mathbb{\mathrm { E }}$.}

The doctrine of evolution has been discussed in this thesis under the head of Religion and Philosophy of Cawein's Poetry. Excerpts from his poems prove the poet's belief in this theory. Cawein, like Tennyson, was interested in science and her glorious achievements.

\section{Science.}

Miranda-like, above the world she waves

The wand of Prospero; and, beautiful, Ariel the airy, Caliban the dull, Iightning and steam, - are her unwilling slaves.

\section{$\frac{\text { Oglethorpe University. }}{(\text { Atlanta, Ga.) }}$}

She shall stand

For what truth means to man;

For science and for art and all that can

Make life superior to the things that weight

The soul down.

\section{Poetry and Philosophy.}

-............. From the stars that burned

Above the mountains ether, Science learned

The first vague lessons.

One Day and Another.

I could not tell you how disease hid me a viper germ, precedence slowly claiming and so slowly fixing firm. 
by Science today. A young girl suffering from tuberculosis breaks the engagement with her betrothed on account of her diseased body.

\section{$* * * * * * * * * * * * * *$ \\ Music. \\ The Valley of Music.}

Then she flung in her song the emotion, Triumphant of heart and of soul;

Till the passion and pain were an ocean

That swept her with billowing roll.

Husic.

Thou, ob thou!

Thou of the chorded shell and golden plectrum, Thou of the dark eyes and pale pacific browl Music.

Touch with thy all - mellifluous finger-tips or thy melodious lips,

This sickness named my Soul.

\section{$\underline{A} \underline{\underline{t}}$.}

Cawein frequently refers to art in his poetry and in his Song of Songs he says:

"Art that is voice and vision of the soul of man." Beauty and Art.

To him - whatever facts may say -

Who sees the soul beneath the clay

Is proof of a diviner day.

That lifts the soul above the clod, And, working out some period 
Of art, is part and proof of God.

$* * * * * * * * * * * * * * *$ 


\section{HIS POETRY SHOWS INTLEREST IN THB FOLIONIING}

\section{PHASHS OH LIFI:}

\section{The Humble.}

Cawein's poems of the farm give us a true picture of country life and he sings of the joyousness of this simple way of living. Some of the poems of this class are:

on the Farm,

The Farmstead,

Evening on the Farm,

The Vintager, etc.

\section{On the Farm.}

He sang a song as he sowed the field,

Sowed the field at break of day:

He trilled a song as he mowed the mead, Mowed the mead as noon begun.

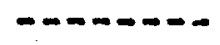

He humed a song as he swung the flail,

Swung the flail in the afternoon.

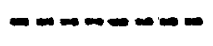

He whistled a song as he shouldered his axe,

Shouldered his axe in the evening storm:

"When the snow of the road shows the rabbits' tracks And the wind is a whip that the Winter cracks, With a herdsman's cry, o'er the clouds black backs, Halloo and oht

Halo for home and a fire to warm!" 
The Vintager.

Among the fragrant grapes she bows;

Long violet clusters heap her hands;

And with bright brows on him bestows

Sweet looks, like soft commands.

And from her sunburnt throatat times, As bubbles burst on new-made wine,

A happy fit of merry rhymes

Rings down the hills of vine.

And in his heart, remorseless, sweet Grew big the red-grape, passion, there;

His heart that ever at her foet

Was filled with love's despair.

But she, who ne'er the honeyed must

of love had drained, a grown-up child,

Saw in him - merely one to trust -

And broke his heart and smiled.

The Old Herb Man paints a picture of old age, forlornly poor.

on the barren hillside lone he sat;

on his head the wore a tattered hat;

In his hand he bore a crooked staff;

Never heard I laughter like his laugh,

on the barren hillside, thistle-hoar. 
Cracked his laughter sounded, harsh as woe;

As the croaking, thinned of a crow:

At his back hung pinned a wallet old,

Bulged with roots, and simples caked with mould:

on the barren hillside in the wind.

There is nothing sadder than old age;

Nothing saddens more than that stage

When forlornly poor, bent with toil,

One must starve or wring life from the soil,

From the barren hillside wild and hoar.

Down the barren hiflside slow he went

Cursing at the cold, bowed and bent!;

With his bag of mold, herbs, and roots

In his clay-stained garments, clay-caked boots

Dow the barren hillside, poor and old.

The old Swing brings back memories of childhood days to one who is watching a child in the gwing.

Under the boughs of spring

She smung in the old rope-swing.

Her cheeks, with their happy blood,

Glowed pink as the apple-bud.

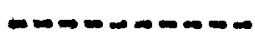

And I - who leaned on the fence-

Watching hor innocence

Had given the rest of my years, 
With their blessing and hopes and fears

To have been as she was then:

And just for a moment again

A boy in the old rope-swing

Under the boughs of spring,

\section{Mountain and Feud Iife.}

Cawein portrays mountain life in Kentucky in Dead Man's Run, Moonshiners, and foud Iife in the Feud, Lynchers, Ku Klux, The Man Hunt.

\section{Dead Man's Run.}

He rode adown the autumn wood,

A man dark-eyed and brom;

A mountain girl before him stood

clad in a homespun gown.

"To ride this road is death for yout

My father waits you there;

My father and my brother too -

You know the oath they swear."

These lovers elope and as they ride they meet her

father and brother who fire rifle shots at him. Finally the lovers are drowned in the stream.

\section{Ku Klux.}

We have sent him seeds of the melon's care, And nailed a warning upon his door; 
By the Ku Klux laws we can do no more.

Only a signature, written grim

At the end of the message brought to him -

A hempen rope and a tristed limb.

So arm and mount 1 and mask and ridel

The hounds can sense though the fox may hide:

For a word too much men oft have died.

\section{The Lynchers.}

At the moon's down-going let it be

On the quarry hill with its one gnarled tree.

The rocks that ooze wi th the hue of lead,

Where we found her lying stark and dead.

The scraggy wood; the negro hut,

With its doors and windows locked and shut.

A secret signel; a foot's rough tramp;

A knoch at the door; a lifited lamp.

A group of shadows; the moon's red fleck;

A running noose and a man's bared neck.

A word, a curse, a shape that swings;

The lonely night and a bat's black wings. 


\section{Gipgy Iife.}

The poem of the gipsy maiden, Flamencine is full of beauty and tender pathos for that class of society that always seems to possess the spirit of romanticism.

It was a gipsy maiden

Within the foreat green;

It was a gipsy maiden

Who shook a tambourine:

The star of ere had not the faee,

The cascade's' foam had not the grace

$$
\text { of Flamencine. }
$$

\section{$* * * * * * * * * * *$}

Her bodice was of purple,

Her shoes of satin sheen;

Her bodice was of purple

With scarlet laid between:

The wind of eve was in her tread,

The black of night was on the head

$$
\text { of Flamencine. }
$$

\section{$* * * * * * * * * * *$}

There lies a gipsy maiden

Within the forest green;

There lies a gipsy maiden

Beside her tambourine:

These many years I am her slave -

The violets gorw upon the grave

$$
\text { of Flamencine. }
$$

Carmen is the same fascinating gipsy girl of old Seville, who coquettes with the Spanish soldiers. Proud, wicked head, and hair blue-black 
Whence the mantilla, half throw back,

Discovered shoulders and bold breast.

Bohemian brown. And you were dressed

In some short skirt of gypsy red

of smuggled stuff; and stockings, -dead

White silk. -........-Flirtingly

You walked by me: and I did see

Your oblique eyes, your sensuous lip

That gnawed the rose I saw you flip

At bashful Jose.

........... I saw you dance

With wily motion and glad glance,

Voluptuous, the wild romalis,

Where every movement was a kiss.

Some st1ll night in Seville: the street

Candilejo: two shadows meet:

Swift sabres flash within the moon-

Clash rapidly - A dead dragoon.

$* * * * * * * * * * *$

We find in the works of Cawein several poems touching life in the slums and the vampire theme made famous by Kipling. Those are:

of the Slums,

The Woman Speaks,

A Woman of the World,

The Vampire.

$* * * * * * * * * *$

of The Slums.

Red-faced as old carousal, and with eyes

A hard, hot blue; her hair a frowsy flame, Bold, dowdy bosomed, from her window frame 
She leans, her mouth all insult and all lies.

The flaring lights of alley-way saloons

The reek of hideous gutters and black oaths

of drunkenness from vice-infested dens

Are to her senses what the silvery moon's

Chaste splendor is

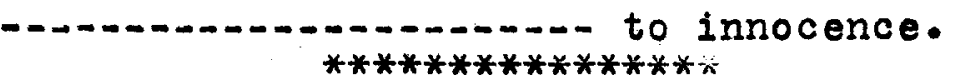

The Woman Speaks.

Why have you come? To see me in my shame?

A thing to spit upon, despise and scorn?

You, you who ask mel You by whom was torn

Then cast aside, like some vile rag, my namel

$* * * * * * * * * * * * * *$

The Vampire.

I drew her dark hair from her eyes, And in their deptho beheld a while

Such shadowy moonlight as the skies Of Hell may smile.

God shall not take from me that hour

When round my neck her white arms clungl

When Ineath my lips, like some fierce flower, Her white throat swang ! 
A selection from Fallo of the Ohio gives a description of the Indian in his native environment and an idea of his habits. Other poems which refer to the Indian are An Inalan Legend, The Ocklawaha, and The Cumberlands.

\section{Falls of the Ohio.}

Here once the Indian stole in natural craft From wahoo-bush to bush, from tree to tree, His head plumes like a bird, below, above, Fiuttering and nodding mid the undergrowth;

In his brown hand the pliant, polished bow, And at his back his gaudy quiver filled With tufted arrows beaded blue with flint.

$* * * * * * * * * *$

\section{The Ocklawaha River.}

Osceolal Osceolat

Phantoms of your vanquished race

Seem around me: overawe

All my soul here. Hossy regions

Swarm with Semieles:lost legions

Rise, the war-paint on each face -

Dead, long dead for Florida.

$* * * * * * * * * *$

\section{The Cumberlands.}

\section{Fireflies}

Gleaming in the tangled glade

Seemed the eyes of warriors,

Stealing under watching stark

To some phantom ambuscade: 
To the tepees there that gloomed, Wigwams of the mistl that slept By the woodland side, whence crept Shadowy Shawnees moonbeam-plumed. 
The Menace deals with the negro race question with which our country has been confronted since the days of slavery. We ask ourselves - What is the solution to this problem? How can we elevate the negro? Is it the Whiteman's fault that the negro is so degraded and revengeful? This is a greater menace than the "yellow peril."

Cawein's poem seems to be a warning finger against the Whiteman's own selfishmess and dearth of feeling for this benighted race.

\section{The Menace.}

The hat he wore was full of holes, And his battered shoes were worn to the soles. His shirt was a rag held together with pins And his trousers patched with outs and ins, A negro tramp, a roustabout, Less safe than a wild beast broken out.

But the bird's glad song and the scent of the rose weant nothing to him of the love man knows. If he heard or heeded 'twas but a curseLove had no place in his universe.

$$
* * * * * *
$$

And there in the lane one met with him A girl of ten who was fair and slim;

A farmer's daughter Innocent, trusting, free from guile, She met his look with a friendly smile. And he? He laughed when the child had passed And a furtive glance about him cast, Then turned and followed. His chance was now 
To serve the Witeman out somehow.

He would get even for many a kick.-

Now was his time to turn a trick.

Next day they found her battered and torn,

Her small child's body hid under a thorn.

And ohl I wonder, good brother of mine,

Why God in His heaven gave never a sign.

Why she, the lovely, the young, the shy,

Iike a beast of the field should have to die;

Wile he, the hideous, kin to the ape,

God in His heaven should let escape.

$* * * * * * * * * * * *$

The Ghost reveals the psychological effect of fright upon the negro ind and shows that the poot well knew the attitude of the race under certain mental stimulus.

\section{The Ghost.}

Here's a house across the street

That nobody goes into;

Say it's haunted, yes, they do;

Ghosta I1ve there, they say, or meet:

Saw one in a winding sheet

At a window once and took

To my heels and ran and ran,

Never gave another look,

Till I met a nigger-man.

And I told hin. And he sald

"Dat ole house am ha'nted sure.

'Deed it was a ghostl A pure 
Sure nuff ghost, I am afred.

-n-n-n- Lawzy mel

I won't pass that house ter-night.

onct I passed under dar: whut'd I see?

Why, I seed a walking light.

"Yep: and it went up and down

Like a fire-bag. I maz skeered

Wus'n you wuz. And I heered

Chains a-tramping all aroun':

And I laid dar on de groun'

Skeered to def. And then I seed -

Whut'd yer reckon? seed- my lands!

Seed a mition hands.

"Den I run'd jest like you did-

ought ter t'ar dat ole house down."

Who does not remember in the days of his youth "The Charcoal Man," with his sooty face and croaking voice, who is surrounded by a crowd of mimicking boys?

Cawein's poem gives us a good view of this phaseof life, and our sympathy goes out to that class of society that earns its bread crying through the streets.

once a charcoal wagon passed

And an old black charcoal man,

"Blacker than a midnight blast",

Mother said. And he began

Crying,"Charcoal! charcoal!

Come and buy my charcoal."

And the boys they mocked him so. 
But he never looked at them, Only cracked his blacksnake whip, Sucking at his old pipe-stem. Not much blacker than his iip Crying, Charcoal I Charcoal I"

And the boys they mimicked him While he rode on black and grim:

Down he got then from his team, In his old patched coat and hat Rags and dirt at every seam, Elacker than our old black cat Crying, eharcoal - - - - ." And the boys they stood far off, Mocking him with gibe and scoff:

I felt sorry for him then: And my mother called him in:

Bought a boxfuI. Gentlemen!

Ought to 've seen him laugh and grin Crying, "Charcoal! $1 "$

************

The Miser is another window through which the poet observes life in a beggar's coat, clutching his hoards of gold.

Withered and gray as winter; gnarled and old, With bony hands he crouches by the coals; His beggar's coat is patched and worn in holes; Rags are his shoes: clutched in his claw-like hold $-80-$ 
A chest he hugs wherein he hoards his gold.

Let the winds howl and let the palsy twitch

His rheum-racked Iimbs; here's that will make them glow

And warm his heartl - - - - - - - - -

How the gold glistensl Rich he is how rich -

Only the death that knocks outside shall know.

$* * * * * * * * * * * * * * * * *$

Cawein's love and sympathy for children are indicated in his poetry for children. He has witten a number of poems revealing their imaginative faculty, their simple credulity and childish ways. A few of those poems are:

Bad Iuck, Ragamuffin, The Boy Next Door, Iand of Candy, Boy on the fiarm, The Poppet Show, Little Boy and His Shadow, etc.

$* * * * * * * * * * * * * * *$

Bad Iuck.

Once a rabbit crossed my road

When I went to see my aunt;

And another time a toad

Hopped right in my way. - You can't

Kill toads, for that makes it rain,

And would spoil your day again.

He then recounts the bad luck he had because the rabbit crossed his road. He fezl out of bed that night, stumped his toe, and got a whipping.

No sir, I don't want to see

Any rabbits anyways

Cross my road. Why ${ }_{-8 I-}$ Geemenie! 
If I saw one - only one,

I would turn and run and run.

$* * * * *$

\section{Ragamufin.}

But the worst thing that he does,

So I think, is poking fun

At poor beggars

And he laughs

Fit to kill, and apes, and chaffo

Every cripplel lies in wait

Just to mock: pretends he's lame:

Jeers then, "Sayl Why ain't you straight?

Ragamuffin is his name.

$* * * * *$

Boy Next Door.

There's \& boy who lives next door;

And this boy is just as bad

As a boy can be: and poor !

- out at knee;

And no shoes; and more than that,

Hardly any shirt or hat

He's as poor as Poverty.

$* * * * *$

But I like him: yes, I do.

He can play most any game,

And tell fairy stories too;

Funny stories, just the same

As my father does. And he

told me one about a frog,

Living near a lake or bog,

Frog that marrited a bumblebee. 
(and) the old witch that

Sits before the fire alone

Frying fat for her black cat.

$-84$ 


\section{Historic Periods.}

Cawein revives the Arthurian period of romance in Accolon of Gaul, Peredur and Isolt, the French period in the Troubadour and Love As It Was In The Time of Louis XIV, Iife in the Orient, in Behram and Eddetma, Jaafer the Barmecide, and Ishmael; Norse mythological period in Loke and Sigyn; and his frequent references to the Greek myths bring to our minds the golden age of Greek literature in which we find the living, throbbing, surging heart of Greece. 


\section{HUMAN POETRY OF WORDSWORTH.}

Wordsworth's exaltation of Nature gives humanity a secondary place. He set himself to understand, so far as he might, the human agency which co-operate with external powers, and makes beauty and grandeur posstble. He also learned and taught

"liow the mind of man becomes

A thousand times more beautiful than the earth on which he dwells."

Wordsworth does not dissect the human mind as Browning does; but he watches it at work, in the hope that among the attitudes into which it is thrown he may find some ald to his vision.

The fascination that children bad for him is best illustrated by the poems founded on incidents of his conversation with them. He was attracted by the very indifference of children to the things on which he was brooding. In the ode he says:

"Thou eye among the blind,

That deaf and silent, read'st the eternal deep, Haunted Forever by the eternal mind."

In We Are Seven the simplicity of the little cottage girl, her refusal to share in his wonder at the mysteries of Iife and death seem to him a marvellous thing. In the Anecdote for Fathers he asks the little boy if he would rather be at Kilve, by the sea-shore, or here at Liswyn farm. In the poem called Beggars he writes of two ragged boys who are in the wildest high spirits chasing a butterfly. What could be more natural in our own childhood than chasing a butterfly! 
I did espy

A pair of little boys at play

Chasing a crimson butterfly;

The taller followed with his hat in hand,

Wreathed round with yellow flowers.

$* * * * *$

Wordsworth's observation of peasantry yielded him the best and finest part of his poetic harvest. Here, he thought, are none of the deceits of idle fashion, the social vanities and the intellectual pretensions that overlay the fundamental facts of life in a more ambitious society.

Wordsworth was resolved to reduce human life to its lowest terms, to see whether it is in itself a thing of worth. The men who pass their lives under a weight of labor and hardship, battling for bare subsistence, would be able, he thought, to tell him more than all the theorists and economists. "There I heard," he says,

From mouths of men obscure and lowly, truths Replete with honor.

Among the vagrants and beggars and pensioners who were his chosen subjects he found those qualities which gave Rome her empire, in the ancient world. Thus he saved his poetry from that touch of unreality and brought it back to the miracles that transform the face of daily life.

The 0ld Cumberland Begsar is, like the Leech-gatherer, a commissioner from Heaven, calling forth, wherever he passes, acts of human kindness, pity and love.

He sat, and ate his food in solitude:

And ever, scattered from his palsied hand, That, still attempting to prevent the waste, 
Was baffled still, the crumbs in little showers Fell on the ground.

$* * * * *$

Peter Bell is a being compounded of the elements. His face was keen as was tho wind

That cuts along the hawthorn-fence;

There was a hardness in his cheek,

There was a hardness in his eye.

$* * * * *$

Wordsworth loved to write of the humble and rustic

Iife because in that condition he says, "The essential passions of the heart find a better soil in which they can at tain their maturity, and are less under restraint, and can speak a plainer and more emphatic language; and because our elementary feelings co-exist in a state of greater simplicity. In the following lines we find scenes of lowly and pastoral life heightened by generic interest:-

\section{Lucy Poems.}

She dwelt among the untrodien ways Beside the springs of Dove, A maid whom there was none to praise And very few to love.

A violet by a mossy stone

Half hidden from the eyel

Fair as a star when only one

Is shining in the sky.

$* * * * * *$

\section{Michael.}

Upon the forest side in Grasmere Vale

There dwelt a shepherd, Michael was his name; $-88$ 
An old man, stout of heart and strong of limb.

$* * * * *$

The Wanderer.

liany a passenger

Hath blessed poor Margaret for her gentle looks

When she upheld the cool refreshment dram

From that forsaken spring.

$* * * * *$

In the White Doe of Rylstone, or the Fate of the Nortons, the poet summons all the powers of grief and anguish to do their worst on a single devoted soul.

The inevitable doom that falls on Richard Norton and his sons is foretold to Bmily by her brother Brancis, who bid her take comfort in the thought that she is permitted to go with him to meet it with unblinded eyes.

Weep if that aid thee; but depend

Upon no aid of outward friend;

Espouse thy doom at once, and cleave

To fortitude wi thout reprieve.

When the doom falls Emily suffers and is strong and worthy of the grace of God. She is raised by the force of sorrow beyond the reach of any further disturbance of the soul.

Her soil doth in itself stand fast,

Undaunted, lofty, calm, and stable,

And awfuliy impenetrable.

Wordsworth was not a dramatic poet; and he did not explore the darkest recesses of the soul, but he portrayed humble and lowly life in its natural surroundings.

His emotional enthusiasm for the French Revolution had humanized him and brought him out of the sacred cloister of 
Nature to be with the poor and simple of humanity. $-90-$ 


\section{TENNYSON.}

\section{HUMAN POETRY.}

Frederic Harrison, speaking of the literary production of the Victorian ara, says:

"Our literature today has many characteristica; but its central note is the dominant influence of sociology enthusiasm for social truths as an instrument of social reform." *

Iiterature gives life and power to facts which of themselves are inert and dead and brings these facts to the knowledge of multitudes who would otherwise be ignorant of them.

Tennyson faced the gloomy facts of social and industrial life, but beliered that these only imposed the obligation upon all members of society to live together as brethern. Penetrating all disguises and all deceptive appearances, he found the cause of social unrest and suffering and disorder in the selfish spirit that pervades society.

There are hardships which the poor alone suffer and the principles of brotherhood lay upon the rich an obligation to give to their poorer orethern sympathy and aid. This is the teaching we find in Tennyson's human poetry.

There was nothing nobler for the penitent, redeemed Guinevere to do than to give the remnant of her life to the distribution of charity to the poor and sick:

"So let me . . . . .

Walk your dim cloister, and distribute dole

To poor sick people - . -

And treat their loathsome hurts."

$* * * * * * * * * *$

* (Foot-note) Studies in Victorian Literature, F. 13. 
Leonard in Locksley Hale Sixty Years After is exhorted to follow the example of him who

"Strove for sixty widowed years to help his homelier brother men

Served the poor and built the cottage, raised the school and drained the fen."

He praised those who gave to the sick and poverty-stricken. This praise was a part of the honor accorded Marie Alexandrovna

"Whose hand at home was gracious to thy poor."..."

$* * * * * * * * * * *$

In The Promise of May (Act III) the evils of working men wasting their wages at a pothouse are recognized, if not fully and powerfuliy pictured.

The Northern Cobbler gives the most striking dramatic portrayal of the terrible results of the drink habit upon one who has become a slave to it. He lost his customers, abused his wife and child, but at last new light and life came to him only when he resolved with all his might to quit his evil way. And one night I cooms 'hothm like a bull gotten loose at a fallir

............ And I

And I smashed the tables and chairs, and she and the babby betled (crited)

For I knawed naw major what I did nor a mortal beast of the feald.

No poet has yet arisen to do for the enslaved millions of the liquor habit what Harriet Beecher stowe did for the negro in her imaginative prose.

Tennyson looked upon the church as one of the great institutions of organized society and he believed that the 
church exists to meet a real social need.

When men have false ideas of the character of God and of his requirements, superstitions arise, wrons systems of worship and loss of faith in God. The poem Despair was based upon the following incident, which appealed strongly to the poet.

Loss of falth in God and imortality caused a man and his wife, who were utterly miserable in this life, to resolve to end themselves by drowning. The woman was drowned but the man was rescued by a minister of the sect he had abandoned. The poem expresses the despais of a soul from whom faith in God has departed. Thus the rescued man addresses his rescuer:

- nnow you of old -

Small pity for those that have ranged from the narrow warmth of your fold,

Where you bawled the dark side of your faith and a God of eternal rage, Till you flung us back on ourselves, and the human heart, and the Age.

$* * * * * * * * * * *$

In the May Queen we have reference to a highor type of minister:

And that good man, the clergyman, has told me words of peace, 0 blessings on his kindly voice and on his silver hair. 
One distinct danger that society has to recognize and meet is that which comes from marriage for money, rank, or policy. Here the poet held the mirror up to his time, and disclosed the direful results of degrading so sacred an institition by such ignoble motives. No one can read the poems of Teanyson which treat of this subject and be blind to the contempt he feels for the match which is barren of love and is prompted by selfigh or unworthy aims. It is not difficult to detect in such lines as these the real contempt felt by the poet for marriage when Mammon is the priest:- -

She went, and in one month

They wedded her to sixty thousand pounda, To lands in Kent, and messuages in York And slight Sir Robert with his watery smile And educated whisker.

(Edwin Morris)

The crime and sorrow of such an alliance are shown again and again. The woman betrothed to one whose face she loathes, in order to save the ancestral estate, calls to her sister:

The morn appears

When he will tear one from your side, who bought me for his slave;

This father pays his debt with me, and weds me to my grave. (The Flight)

Dora in The Promise of May is confronted by a similar condition, and is tempted to marry Farmer Dobson, whom she "can't abide", because in the financial straits of her family he could "keep their heads above water."

So likewise in The Foresters, Marian was urged to marry one who would pay the mortgage, and the girl spurned the suggestion 
with all the strength of her resolute soul.

Before true marriage can be consummated, God must have wrought "Two spirits to one equal mind." (Miller's Daughter) 


\section{WOMANS.}

Tennyson has witten much concerning the place and mission of woman and has pictured many types of female character. In King Arthur the poet has given us the ideal man, and this beautiful character has no feminine counterpart. Tennyson has portrayed women of mondrous virtue, beauty and love; but there is not one in all the gallery of his art to whom we can point and say:

"This is the ideal woman."

The noblest women of his song are not the creations of his imagination, but the product of his photographic skill. Iilian, Mariana, Madeline, Oriana, Margaret, are not without attractiveness; but when he wrote of Victoria, in whom

A thousand claims to reverence closed

In her as Mother, Wife and Queen;

or of his own mother as he did in Isabel, he wrote with a power not evinced in the descriptive analyses of the women of his imagination.

The women of his brain are pretty girls. The noblest women he knew were strong in character, Iife and love. In seneral it is true that the lines written in earlier manhood portray women whose attractiveness is transient and external, while his maturer genius delighted to present those whose power is in intellect and noble qualities of heart. He views woman primarily frorn the standpoint of sex. The charms of her nature bring warriors to her feet and by her loves she makes and unmakes men and kingdoms. Vivian conquers Merlin. Guinevere dooms the round table to dissolution. The Princess as a college president is a fizzle, but as the beloved of the arnorous prince she is winsome, strong and womanly. 
Tennyson does not sanction the theories of Lady Psyche and Lady Blanche, who maintained

........ That with equel husbandry

The woman were an equal to the man.

He does not join in the effort of the Princess

"To lift the woman's fallen divinity

Upon an even pedestal with man."

Wuch less does he approve of the low ideal of the fatfaced Edward Bull

"God made the woman for the use of man

And for the good and increase of the world."

(Edwin Morris)

on the contrary, the fundamental fact is

-............. Bither sex alone

Is half itself, and in true mariage lies

Nor equal nor unequal.

The twoocelled heart beating with one full stroke, Iife. (Princess)

Tennyson was an ardent lover of children and a firm believer in the exalted mission of children in the fanily and the state. It was a child that called forth the tender affection of Guinevere and later it was a child within the cloister, who became the companion of the despairing queen. The child is really the heroine of The Princess and brings the college to senity and success:

The inportance of the child to the family and to society gives to the perils that threaten him very great significance. 
One of the children of Enoch Arden died because of poverty. This was but one of the many such innocent sufferers. In Maud we read of the time

When a Namonite mother kills her babe for a burial fee, And Timour - mamon grins on a pile of children's bones. *****

We now conclude that the human element of Tennyson's poetry is wide and varied. He deals witi problems of state, church, industry, society, man, woman, and child. 


\section{SHERTLEY.}

\section{Human Poetry.}

Huch of Shelley's poetry is dedicated to the service of mankind. It does not treat of human life as we find in Browning, Wordsworth, or Tennyson; but it treats of human life as it may be when it is freed from evils.

Shelley brought those evils forward, described them as he hated them, and caused a great number of people to hate them and oppose them more heartily. Few in poetry have done more to overthrow false conceptions of God, to undo the network of false reverence; to shake the foumdations of injustice, of cruel superstition, of tyranny, of caste, of slavery of mind and body. This is a part of the grave matter of his poetry. He denounced injustice, freedom dear to him, and above all love; and his human poetry is as much steeped in these ideas as a summer garden is in sunshine.

There is no tenderer song of the loveliness and duty of absolute and unrevenging forgiveness than is heard through Shelley's poetry.

These are serious things that he has given to us, and the world will always be grateful for this religious gravity in his teaching. It is a high matter for a poet's work and it will have more and more effect on men; for the whole question of the social future of man is rising in a special way into increasing eminence; and the method Shelley laid down for attaining the perfect state is that of Jesus Christ; and is stated by him with strong reiteration. That method is in direct opposition.to the method of force and punishment. To teach justice and mercy, love and freedom, to lay down spiritual means of 
their attainment and to extol them in exultant verse was Shelley's service to mankind. He was intensely interested in all social problems and he was ever seeking a solution. He believed in goodness, in its ultimate triumph; and he hated materialism both as a philosophy and a practice. He taught the duty of an unworldly life, and he defended the cause of the poor and the workmen. The fragment of Charles I shows that he could go straight to the human matter and wite of it with incisive power.

He is the poet of certain distinct human ideas and of their corresponding emotions. His work shows extraordinary intensity in his feeling towards mankind.

In the following lines he cries down oppression:

\section{Queen Mab.}

Oh many a widow, many an orphan cursed

The building of that fane; and many a father,

Worn out with toil and slavery, implored

The poor man's God to sweep it from the earth. $-\cdots-\cdots-.-n$

For the iron rod of Penury still compels

Her wretched slave to bow the knee to wealth. $* * * * * * * * * * * * *$

The following lines show false conceptions of religion and God:

Twin-sister of Religion, Selfishness,

Rival in crime and falsehood, aping all

The wanton horrors of her bloody play.

The self-sufficing, the omnipotent,

The merciful and the avenging God, - 
Who, prototype of human misrule, sits

High upon a golden throne.

$* * * * * * * * * *$

Towards a social change shelley's work in poetry concerning mankind is an element of power; and it moves far more strongly than is believed among the numerous body in the working classes who think and feel concerning the condition of humanity .

Shelley was a true child of the French Revolution. His radical spirit expressed itself in an unrestraining denunciation of the past with its tyrannical government of kings and emperors.

Queen Mab is Shelley's first poem of importance, boldly professing his radical ideas, and it is a fierce diatribe against kings, priests, religion, and palitical government. It was a systematic attack upon the institutions of society. Unlike Queen Mab, the second revolutionary poem, the Revolt of Islam, did not aim to expound any system of political ideas. It was written solely to stir up emotion and enthusiasm for liberty and reform. It endeavored to show that love was the sole law which should govern the moral world.

Prometheus Unbound, the last finished revolutionary poem, presents in an allegorical way the program of queen Mab. It is a drama, dressed in the garb of the ancient Greek, but with the soul of modern times. Jove is the personification of law and tyranny; he stands for the kings and priests of Queen $\mathrm{Mab}$. Prometheus is, the human spirit chained by the tyranny of Jove, yet with an unconquered will. Asia, his promised bride, is the spirit of love in Nature. The Triumph of Iife, another revolutionary poem, was left as a fragment. Hence we see that Shelleywas intensely interested in the social 
institutions and reforms of mankind.

The women we find in Shelley's poetry melt into philosophic mist, or are used to build up a political or social theory.

Cyntha, Rosalind, Asia, Bmilia are 1deas, not realities in flesh and blood.

Beatriceis alive, but she was drawn for him in the records of her trial. The Cenci is Shelley's tragedy. Here we find the dramatic situation strong, especially the attitude of Beatrice resisting her father. In this drama the poet is confessediy great, and we discern the noble image of that courageous and enduring element in Shelley himself which gives force to his gentleness and dignity to his innocence.

The following passage shows the undaunted strength and fearlessness of Beatrice:

(Beatrice)

Tortures I Turn

The rack henceforth into a spinning-wheel 1

My pangs are of the mind and of the heart

And of the soul: ay of the inmost soul,

Which weeps within tears as of burning gall.

Beatrice is a gentle, loving woman, yet firm and strong, accepting death fearlessly. 


\section{Humanity.}

The Genius of Browning, with his broad knowledge of humanity, has evolved out of the clash of human passions many men and women with powerful emotions, because he had the gift of ginging straight from the heart, and was fearlessly truthful in his presentation of human nature; and because he was drawn by his dramatic bent to the strong situations which can not be evolved out of mild sentiments.

In this fearlessness, as well as subtlety of his psychology, he stand with Balzac rather than with his contemporaries of England.

Browning represented as far as he could all types of .human nature; and, more audacious still, types taken from many diverse ages, nations, and climates.

He wrote of times and fold as far apart as Caliban and Cleon, as Karshish and Waring, as Balaustion and Fifine, as St. John and Bishop Blougram. The range and contrasts of his subjects are equally great. He did this work with a searching analysis, a humorous keeness, a joyous boldness, and an opulent imagination at once penetratrice and passionate. I do not think he ever repeats any one of his examples, though he always repeats:his theory, and they are likely to charm, at least by variety, for they are taken from all ages of history, from as many diverse phases of human act, character, and passion as there are poems which concern them; from many periods of the arts; from most of the countries of Europe, from France, Germany, Spain, Italy, with their specialised types of race 
and of landscape; and from almost every class of educated modern society. He picked up his subjects as a man culls flowers in a mountain walk, moved by the ever-recurring joy and fancy in them - a book on a stall, a bust in an Italian garden, a face at the opera, the market chatter of a Tuscan town, or a picture in sorne Accademia:

None since Shakespeare has had a wider range. His portraiture of life was so much more varied than that of Tennyson and so much more extengive and detailed.

Browning often based his poems on the history of times, climes, and peopie as we find in The Ring and the Book all Rome painted to life, and all the soul of the time. The same historic work was done for phases and periods of the Arts from Greek times to the Renaissance and down through the nineteenth century.

Balaustion's Prologue concentrates the passage of dramatic poetry from Sophocles to Buripides. Aristophanes' Apology realises the wild license in which art and freedom died in Athens, and the passionate sorrow of those who loved what had been so beautiful. Cleon takes us into a later time when men had ceased to be original, and life and art had bocome darkened by the pain of the soul.

Periods and pheses of art and religious history are equally realised. Caliban upon Setebos begins the record of religious history; then follows study after study, from A Death in the Desert to Bishop Blougram's Apology.

Sordello stands out as the history of a specialised soul, with ita scenery and history vividly medieeral. The 
Spanish Cloister, The Labratory, A Grammarian's Funeral, The Bishop Orders His Tomb, each paints a historical period or a vivid piece of its life.

Browning's most intense war incident is taken from the history of the French wars under Napoleon, and Herve Riel is another ringing and dashing poem of war.

He does not write, as Tennyson loved to do, of the daily life of the English farmer, squire, miller, and sailor, but of the work-girl Pippa, at Asolo, the Spanish monk in his garden, the Arab in the desert, the Duchess flying through the mountains of Mildavia, poor painters at Fano and Florence, the threadbare poet at Valladolid, the peasant girl who fed the Tuscan outlaw, the Jews at Rome, and of the girl at Pornic with gold hair. Browning resolved to dedicate his art and life to love of Humanity, that pale dishevelled girl, unlovely and lovely, evil and good; and to tell the story of individual men and women, and of as many as possible; to paint the good which is always mixed with their evif; to show that their failures and sins point to a success and goodness beyond, because they emerged from aspiration and aspiration emerged from the divinity at the root of human nature.

All passions, feelings and emotions are found in Browning's characters from the wild cry of dospair of ottima and sebald steeped in sin, the worldly Bishop Blougram, the charlatan Sludge, the shrewd, discerning "Tertium Quid," the spiritual growth of Paracelsus, the philosophical Rabbi Ben Ezra, the soul of music in Abt Vogler, the lack of soul in the art of Andrea Delisarto, the strong pure love of Caponsacchi, the beautiful mother love of Pompilia, John's faith in Christ in A Death in the Desert to Browning's own deep worshipful love for Elizabeth 
The excerpts which follow show characterization.

\section{Pippa Passes.}

(Ottima) Beggar-my-slave- a fawning, cringing lie! Ieave mel Betray mel

A lie that walks, and eats and drinks.

(Sebald) I, having done my deed, pay too its pricel

I hate, hate, curse you. -

My brain is drowned now: All I feel

Is a hurry-down within me as of waters

Loosened to smother up some ghastly pit -

There they go - whirls from a black fiery sea.

$* * * * * * * * * * *$

Bishop Blougram'B Apology.

With me, faith rneans perpetual unbelief

Kept quiet like the snake ineath Michael's foot

Who stands calm just because he feels it writho.

$* * * * * * * * * * *$

Wr. Sludge, "The Medium."

They had their peep into the spirit-world.

................ I cheated when I could

Rapped with my toe-joints, set sham hands at work, Wrote down names.

\section{$* * * * * * * * * *$ \\ The Ring and the Book.}

(Tertium Quid) His wife's heart swealed her bodice, joyed its $f i l l$

When neighbors turned heads wistfully at

church,

Sighed at the load of lace that came to pray.

$* * * * * * * * * *$

\section{Paracelsus.}

Let rnen

Regard, and the poet dead long ago

Who loived too rashly; and shape forth a third

And better-tempered spirit warned by both. 


\section{Andrea Del Sarto}

Ah, but a man's reach should exceed his grasp, Or what's a heaven for? All is silver-gray Placid and perfect with my art.

\section{$* * * * * * * * * *$}

\section{Abt Vogler.}

But here is the finger of God, a flash of the will that can That out of three sounds he frame, not $\overline{-}$ a fourth $\overline{-}$ sound but $* * * * * * * * * *$ a star.

The Ring and the Book.

(Caponsacchi)

Unless you sufter me wring drop by drop liy brain dry, make a riddance of the drench

of minutes with a memory in each

Recorded motion, breath or look of hers Which poured forth would present you one pure glass Mirror you plain-As God's sea glassed in gold, His saints - the perfect soul Pompilia.

(Pompilia) I never realized God's birth before. How he grew likest God in being born. This time I felt like Mary, had my babe Lying a littie on my breast like hers.

$* * * * * * * * * * *$

\section{A Death in the Desert.}

- The acknowledgment of God in Christ Accepted by thy reason, solves for thee All questions in the earth and out of it.

\section{$* * * * * * * * * *$}

Many passages in Browing refer to his love for

Mrs. Browning; By the Fireside, the last lines of Prospice, and the dedication to her of The Ring and the Book. 
We shall now consider Browning's special view of human nature, human life, and the relation of both to God. It marks his originality that this view was entirely his own. Ancient thoughts of course are found in it, but his combination of them is original. His theory is partly shaped in Pauline and fully set forth in paracelsus.

He asks what is the secret of the world; of man and man's true purpose, path and fate. He proposes to understand God and his works and all God's intercourse with the human soul.

We are here, he thinks, to grow enough to be able to take our part in another life or lives; but we are surrounded by limitations which baffle and retard our growth. That is miserable but not so much as we think; for the failures these limitations cause prevent us - and this is one of the main points in Browning's theory - from being content with our condition on earth. There is that within us which is always endeavoring to transcend those limitations, and which believes in their final dispersal. This aspiration rises to something higher than any possible actual on earth. It is never worn out; it is the divine in us; and when it seems to decay, God renews it by spiritual influences from without and within, coming to us from Nature as seen by us, from humanity as felt by us, and from himself who dwells in us.

If we take this world and are satisfied with it, cease to aspire, beyond our limits, to full perfection in God; if our soul should ever say, "I want no more; what I have here - the pleasure, fame, knowledge, beauty, or love of this world - is all I need or care for," then we are indeed lost. The worst failure is better than contentment with the success of earth; and seen in this light, the fallures and misery of earth are actually $-208-$ 
good things, the cause of a chastened joy. Our failures are prophecies of eternal successes.

Two points are then clear in Browning's theory:

I. The attainment of our desires for perfection, the satisfaction of our passion for the infinite is forbidden to us on earth by the limitations of life. We are made and kept imperfect here; but we must do all our work within the limits this natural imperfection makes.

2. We must, nevertheless, not cease to strive toward the perfection unattaintable on earth, but which shall be attained hereafter. Our destiny, the God within us, demands that; and we lose it, if we are content with our earthly life, even with its highest things, knowledge, beauty or love.

The failures of earth prove the victory beyond: For What is our failure here, but a triumph's evidence

For the fulness of the days? Have we withered or agonised?

Why else was the pause prolonged but that singing might issue thence?

Why rushed the discords in but that harmony should be prized?

(Abt Vogler)

Love opens heaven while Earth closes round us; and at last limitations cease to trouble us. They are lost in the vision. Therefore in this confused chaotic time on earth -

Earn the means first. God surely will contrive Use for our earning.

Others mistrust and say: "But time escapes; Live now or never !"

He said, "What's time? Leave Now for dogs and apes! illan has Forever!"

\section{(A Grammarian's Funeral.)}

To see a good in evil, and a hope In $i l l$-success. -............ If I stopp

Into a dark tremendous sea of cloud, It is but for a time; I press God's lamp

Close to ny breast; its splendor, soon or late, Will pierce the gloom: I shall emerge one day. 
So in Ia Saisiaz" earth is man's probation place" by which he finds perfeation in the life beyond the grave. 
The theory of hurnan life which Browning conceived underlies the poems.

The subject of the arts, from the earliest music and poetry to the latest, interested Browning profoundly; and he speaks 01 them, not as a critic from the outside, but out of the soul of them, as an artist. He is the only poet of the nineteenth century till we come to Rossetti, who has celebrated painting and sculpture by the art of poetry; and Rossetti did not link these arts to human life and character with as much force and penetration as Browning. Browning saw that the source of all art wes love.

The poem Abt Vogler is dedicated to music. The substance of the poem is this: When I, Abt Vogfer,touched the keys I called the spirits of sound to me, and they have built my palace of music. For a moment I touched in my music the infinite perfection; but now it is gone; I can not bring it back. This was a flash of God's will which opened the Eternal to re for a monent; and I shall find it again in the eternal life.

With this thought he returns to hurnan life, content to labor in its limits and the common $c$. Major Chord is his.

All we have willed or hoped or dreamed of good shall exist; The high that proved too high, the heroic for earth too hard,

Are music sent up to God by the lover and the bard. Give me the keys. I feel for the common chord again, The C. Wiajor of this life. 
Another poem on the arts, which is mixed up with Browning's theory of life is Andrea del sarto.

Andrea has chosen earthly love; Lucrezia is all in all; and he has reached absolute perfection in drawing - "I do what many drean of, all their lives."

He can reach out beyond himself no more. He has gained the earth but lost the heaven. He says, "The soul is gone from me, that vext, suddenly-impassioned, upward-rushing thing, with its play, insight, broken sorrows, sudden joys, pursuing uncontented life. Others who aspire reach a heaven shut out from me. Iucrezia, I am judged."

Ah, but a man's reach should exceed his grasp, Or what's a heaven for? AII is silver-grey, Placid and perfect with my art: the worse!

The next poem on art is the second part of Pippa passes. Jules, the French artist, in his work, in his pursuit of beauty, has found his full content - his heaven upon earth; but now the living love of a woman has stolen in, and he finds her an uneducated girl; and his dream of perfection in the marriage of art and love vanishes. Having failed in art and love, he passes into a higher conception of both and makes a new world in the wornan and in the art.

His first new sculpture will be the creation of her soul.

$$
\text { And further, to evoke a soul }
$$

From form -...... This new soul is mine! 
Fra Iippo Lippi is another art poem also A Toccata of GaIuppi's.

Sordello, Aprile, and the poet in Pauline give a sketch of the poetic art.

The natural man in Sordello was eager to seize what actual joys were within reach but was prevented by the poet side of his nature - the side which aspired to the ideal.

Browning believed that a living spirit was in the marble which aided the sculptor and even did some of his work. This is a subtle thought peculiarly characteristic of Browning's thinking about painting, music, poetry, or sculpture.

Knowing and feeling the spirit of art we may well call Browning the poet of art. 


\section{WOMANHOOD IN BROWNING.}

We now pass to another characteristic of Brownine's genius and work. An interest in events, in the actions of men and women, is universal in human nature. On the contrary an interest in the anatomizing and laying bare of the workings of the mind is a scientific tendency, shared only by the intellectual attitude in depicting subtleties of character and psychological situations not knowr since the days of Chaucer and Shakespeare. Shakespeare gave us the widest and keenest analysis of the human heart and mind; Cheucer was the second great English poet to do this; and Browning the third.

pauline is the first woman we meet in his poetry. She is a twofold person, exceedingly unlike the woman usually made by a young poet. She is not only the rauline, idealised and also materialiged by the selfish pasion of her lover, but also the real woman whom Browning has conceived underneath the lover's image of her.

Michel, in faracelsus, is a mere silhouette of the sentimental German Frau, a soft sympathiser with her husvand and with the young eagle Paracelsus. She is set in a pleasant garden landscape. Twice Browning tries to get more out of her and lift her into reality; but the men carry him away from her, and she remains undrawn.

Palma, in sordello, runs through the poem, and her appearances mark turning points in Sordello's development. The poem is not a dramatic characterisation but a magnificent individualisation of palma. She has beauty and intellect - that terrible combination and she lays her magic on Sordello. She dreams of some soul beyond her own, who, coming, should call on all the 
force of her character; and this soul was sordello. Softness and strength, intellect and feeling meet in her. Palma is nobly carved; and the step from Michel, Pauline, and lady Carlisle to her is an imiense one.

In this new outrush of his genius he created Pippa, the Asolan girl from the silk mills, at the other end of society from Palma, and at the other end of feminine character.

Ottima, alive with passion, in the fire of which the murder of her husband seems a mere incident, is an audacious sketch, done in splashes of ungradated color. In the end her love passes from the flesh into the spirit, when self-sacrifice dawns upon her and she begins to suffer the first agonies of redemption. The girls on the steps of the Duomo near the fountain are exceliently drawn and varied from each otiner. In them we find natural grace of soul and tenderness in memory of their childhood.

Fifine at the Fair is partiy a study of that temper which comes and goes in the life not only of poets but of ordinary men and women.

Polyxena, in King Victor and King Charles, is partly the political woman and partly the sensible and loving wife of a strangely tempered man. In her the intellect of the woman is of a higher quality than the intellect of the man.

Nildied and Guendolen are the two women in A Blot in the 'Scutcheon. Guendolen is the incarnation of high-hearted ferninine comion sense, of clear insight into the truth of things, born of the power of love in her. Guendolen is the rock on which we can rest; the woman of the world, yet not worldly; just, strong, and full of love and pity. 
Wildred is the innocent child girl who loves for love's scke, and continues to be lost in her love. The Duchess in Colombe's Birthday is innocent, frank, brave, simple and constant arnong a group of false and worldly courtiers.

No women have been more sweetly, nobly, tenderly, and wiseIJ drawn than Pompilia and Balaustion.

Pompilia, a child of the woman of the streets, grew to beautiful womanhood in mean and vulgar circumstances. When she meets a fine character like Caponsacchi he is touched in a moment by the sight of this star of innocence and spiritual beauty and becomes her soul mate. Her love for her child is deep and tender, and Browning's whole treatment of her motherhood is true and full of feeling.

So vivid is the presentation of Balaustion that she seems to be with us in our daily life. She has the Greek gladness of life, the Greek intelligence and passion, and the Greek harmony. Hade of the finest clay, exquisite and delicate in grain, she is yet strong, when the days of trouble come, to raet them nobly and to change their sorrows into spiritual powers.

Each of Broming's women is distinct from the rest. That is a grect comfort in a world wich, sonetimes through laziness, wi shes to busy itself with classes rather than with personalities. I do not believe that Browning ever net a man or woman without saying to hinself, "Here is a new world; what distinguishes it from the rest - that I will know and describe." 
By comparing Cawein's human poetry with that of sone of the Nineteenth Century poets, and passing juajment from the foresoing selections, we may now state that cawein shows interest in many phases of life, revealing the human passions in their elements but not in their multiform complexities as Browning presents trem.

Wordsworth exalts liature and gives hunanity $a$ secondary piace; Tennyson studies social and incustrial life with the hope of alleviating mankina, and portrays his om love and Erief in "In Iemoriarn;" Shellej's attitude towards life was intense; his poetry is dedicated to the service of nenkind; aro Browing shows a brocier krovilece of huranity than any other English poet ezcept Shakespeare and Chaucer.

Thus we see that Cawein stends in rank with theae poets who likive studied life and its meaning, and sill have found a solution in frith. 


\section{-THE METRIQUE OS MADISON CAWEIN'S POATRY.}

After some study of the metrique and technique of lifadison Cawein's poetry, I have made the following classifications and shall treat each with iliustrations of the metrical scheme.

(1) Madison Cawein's Verses Range, Inclusively, From One-Stress to Seven -Stress Rhythm Waves.

(2) His Stanzas Include Couplets, Tercets, quatrains, and Stanzas fror Five to Fourteen Iines Inclusive.

(3) His Poetry Includes Lyrics, Balleds, Sonnets, Blank Verse and Dramas. 
(1) MADISON CAWEIN'S VERSES RANGE, INCIUSIVELY, FROM ONE-STRESS TO SEVEN-STRESS RHYTHA NAVES.

\section{The One Stress.}

Cawein often uses the one-stress metrical verse, with an anacrusis, in some of his lyrics for poetic effect.

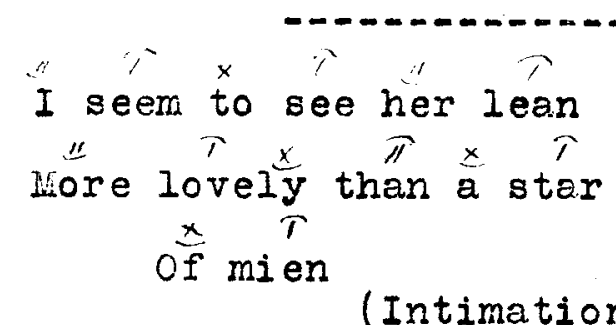

(Intimations.)

$\stackrel{x}{A}$ spirit singing neath the moon

To me.

(Sea Spirit)

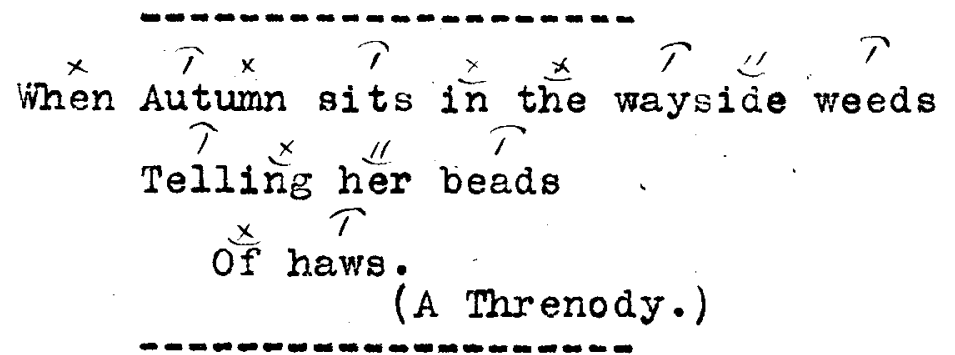

\section{- The Two Stress}

In the following two-stress rhythm waves the alternate

lines are catalectic, both light syllables beine omitted. $\tau \times T \bar{T} x$

Ever a mystery

Here to his heart;

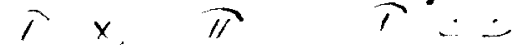

In his life's history

$i$ it

Love played no part.

(Poet's Epitaph)

In the next two lines the poet uses the two-stress in conibination with the three-stress verse.

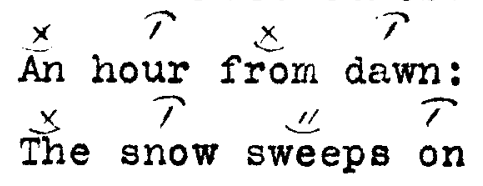




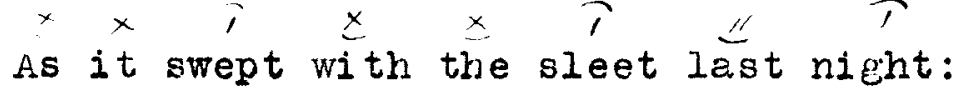

The earth around

II $T \times \underline{T}$

Breaths never $\stackrel{x}{a}$ sound,

Mrapped ir $i \frac{x}{t}$ shroud of $\frac{x}{T}$ white.

(A Belgian Christmas.)

\section{The Three Stress.}

How oft the swallow darted

Above its deeps of blue,

Where leaves close clung or parted

To let the sunlight through

Were roses, honey-heartéd,

Hung full of living dew.

(A Hollow of the Hills.)

$x \quad 7 \times \frac{1}{x} \times \frac{T}{1}$

The moon, like a round device

$\frac{x}{\text { on }} \stackrel{x}{ }$ á shadowy shield of war,

Hangs white $\frac{x}{i n} \frac{x}{a}$ heaven of ice

$x \times T x \rightarrow \frac{T}{T}$

With a solitary star.

\section{(Snow)}

The Four Stress.

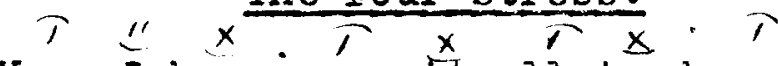

Yes: I have seen it all in dreams:

Naught $\underset{i s}{T}$ forgott $\frac{x}{T}$ - naught $\frac{x}{T}$ seems -

The strangled face, the matted hair,

Drowned, $\frac{x}{f}$ the woman trailing there.

(The Mili-water.)

In the following lines the poet uses the four-stress

trochajc meter to express the supernatural.

Hildegard the daemons name.

Her, who meets $\frac{x}{\prime \prime} \frac{\pi}{\prime \prime}$ on the mountain:

$T \quad T \quad r \quad r \quad \underline{T}$

- Hér, whose hair is like the flame

of a sunset-fevered fountein:

I $\underset{x}{\prime}$ can teli her by her eyes, 
Dreadful eyes of bitter beryl,

Where the anguish never dies, And the suffering soul sits sterile.

(Hildegard.)

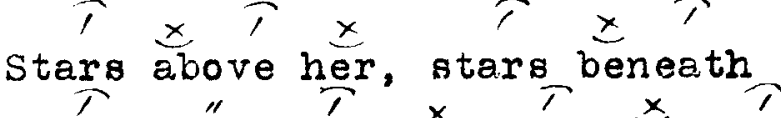

White, she rose as white $\stackrel{x}{a s}$ death.

(Water-Fairy.)

The poet also uses the four-stress dactylic to express

the tragic as in the following lines:

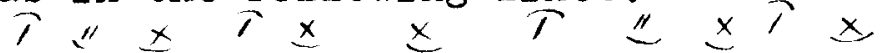

Had I forgotten? and did she remember?

She who is dead, whom $\frac{x}{T}$ cannot forcet:

She, for whose sake all my heart is an ember

covered with ashes of dreams and $\stackrel{x}{\stackrel{x}{t} \text { egret. }}$.

(Ghosts.)

\section{The Five Stress.}

With Chaucer we have the first deliberate use of the fivestress couplet, in continuous verse, known to English poetry.

His earliest use of the pentameter line was in the "Compleynte to Pitee" in the "rime royal" stanae. He uses the pentemeter couplet in the "Canterbury Tales" in his description of "Chauntecleer" and "Pertelote."

\section{Chauntecleer.}

His coomb was redder than the fyn coral, And batailied as it were a castel wall;

His byle was blak, and as the jeet it shoon;

Lyk asure were his legges and his toon;

His nayles whiter than the lylye four, And lyk the burned gold was his colour. 


\section{Pertelote.}

Of whiche the fairest hewed on hir throte

Was cleped faire damoysele Pertelote.

Curteys she was, discreet and debonaire,

And compaignable, and bar hirself so faire.

In Chaucer we find 16,000 lines in this couplet with a variety of cesuras. Although it was an experiment in English verse, it has perhaps hardily been used since with ereater skilI.

Cawein uses this form of verse with artistic grace in his poem "A Sleet-Storm in May."

The lil $\stackrel{x}{y-f i n g e r e d}$ spring came o'er the hilis, Waking the crocus and the daffodils.

$I$ II $x \times$ I $x, T$,

Iife woke and rose ir gold and red and blue; Robed in the starlight of the trembling dew.

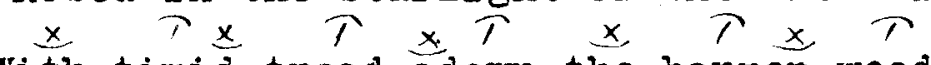

With timid tread adown the barren wood

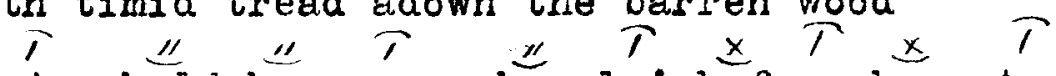

Spring held her way, when lo before her stood Mite-mantled winter, At her breást he tossed A Elittering spear of ice and piercing frost, $\times$ T $T$ T $T$

And struck her down, dead.

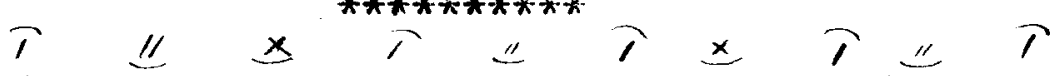
God moves with thee: we seem to hear His feet Wina-like along the floors of heaven beat;

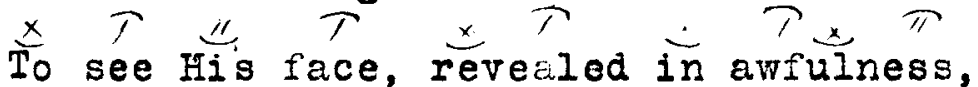

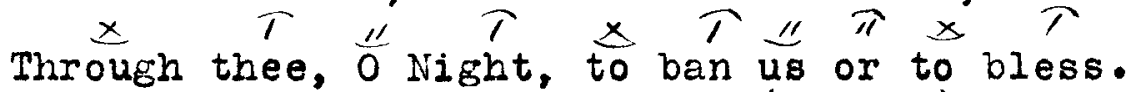
(Night.)

"I ${ }_{0}^{\prime \prime}$ dark-eyed spirit of the marble brow,

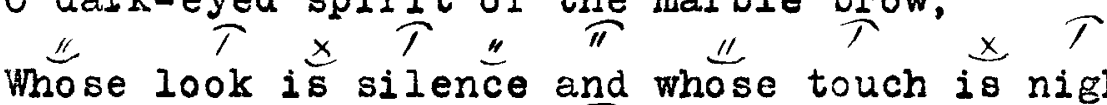
" T $x$ T $x$ and whese touch is night Who walkest lonely through the world, $\overline{0}$ thou,

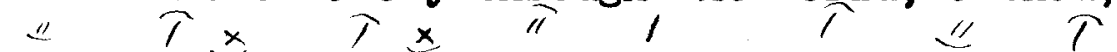
Who sittest lonely with Iife's blown-out light. 
Cawein sometimes comoines the five rijythm waves with

three, showing skili in technique, and creating a rhyme acheme

with the touch of an artist.

The purple priestrosd of the evening waits

With golden pomp within the templed skies;

There is a harp of worship at the gates

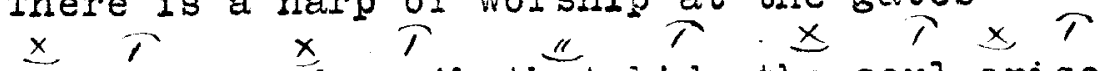

$\frac{x}{o f}$ heaven and earth that bids the soul arise.

With coíunned cliffs and long

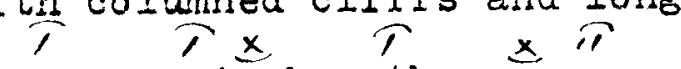

Vales, music breathes among,

Here is the land of Song.

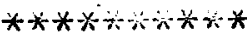

(Youth.)

\section{The Six Stress.}

The Alexandrine, or iambic-hexameter, was introduced into the Inglish from the French about the thirteenth century. It was confused by Widdle Inglish witers with the septenary.

The Alexandrine is not a favorite form because the verse is too long to admit of much variation in placing the cesura. Almost the only important English poems witten in this metre are Drayton's "Polyobion" and Browing's "Fifine at the Fair." Using this form of verse demands a skilful ear and hand to adjust the cadence.

Cawein uses the six-stress verse but not the pure Alexan-

drine in the following lines:

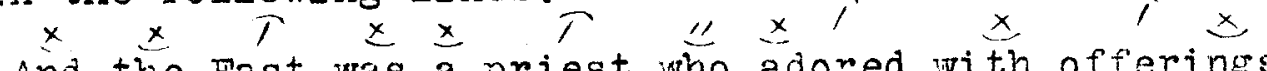
And the sast was $\frac{x}{a}$ priest who adored with offerings And $a$ wonderful cerpet unrolied for the inaccessibie

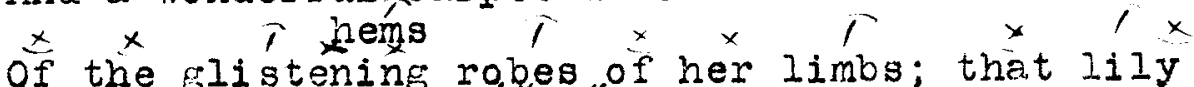
$\pi$ glistening robes, $T x$ ang anethys, $x, x$ Swept glorying on and on through tire temples of cloúd and mist.

(Anthem of Dewn.)

The six-stress metrical line is not often found in Cawein's poetry. 
The septenary, or seven-stress verse, was a farniliar neasure of mediaeval Latin poetry. There it was more commonly trochaic than iambic, as in the famous drinking song of the Goliards:

"Meum est propositurn in taberna mori:

Vinum sit appositum morientis ori,

Ut dicant cum venerint angelorum chori,

'Deus sit propitius huic potatori."

The earliest appearance of the septenary in Inglish is in the "Poema Norale" dated about the year 1170 . The following is a specimen:

"Blessed beo thu; lavedi, ful of hovene blisse Sweet flur of parais, moder of miltenisse;

Thu praye Jhesu Crist thi sone that he me i-wisse, Thare a londe al swo ihc ibeo, that he me ne i-misse." (Hyrin to the virgin.)

Chapman's translation of Homer is an important English poem in the septenary neter.

Cawein useg this verse in "John Davis, Boucanier." "High time, high time, gogd gentlemen, to sail Three months we"ve wátched for galiexong and , treásur'e bound Ior Spain."

Generally the meter breaks up into four and three stresses alternating, as the common metre of hymn books. Cawein does this in "Laus Deo."

In her vast church of glimnering blue, Gray-stóled from feet to chin, Her dark locks beaded with the dew $x \stackrel{r}{\prime \prime}$ "I The nin-like Dawn comes in. 
(2) CAWEIN'S STANZAS IUCLUDE COUPLITS, TERCEIS, QUATRAINS,

\section{AND STANZAS FROM FIVE TO FOURTEEN IINES INCIUSIVE.}

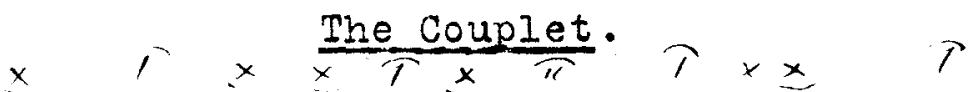

The wind was a wizard who muttering strode

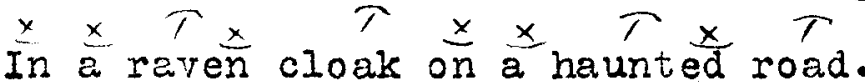

(lioon-ifien.)

\section{Unfulfilled.}

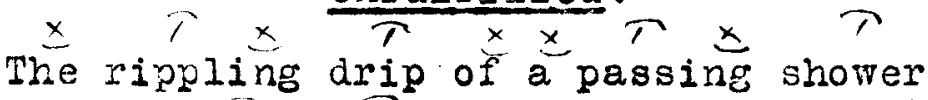

Rinsed wild aroma from herb and flower.

\section{The Tercet.}

$\times$ Before the Tomb.

The way léd unider cedar"edgloom

Whére g'ér the entrance off her toinb,

The moón huing, like a cáctus blóom:

Other examples of poems in tercets are "Tabernacles," "Legend of the Lily," "Wind of Summer," etc.

Tennyson uses the tercet eftectively in "The Two Voices."

\section{The Quatrain.}

The quatrain is the familiar stanze of the early ballads. Many of Cawein's poens are written in quatrains.

\section{On Stony Run.}

No more shall bend her laughing face

Ábove it where the rose is!

sigh softly past the burial-place

Where all her youth $\stackrel{x}{x}$ époses.

Where all her youth.

"Bare Boughs," "Arcturus," "Days and Days," etc. are

expressed in quatrains.

\section{Five Iine Stanzas.}

Some of the poens under this head are:

"Drought in Attumn."

"Assumption."

"Rose Leaves." 
A few of his poems written in this form are:

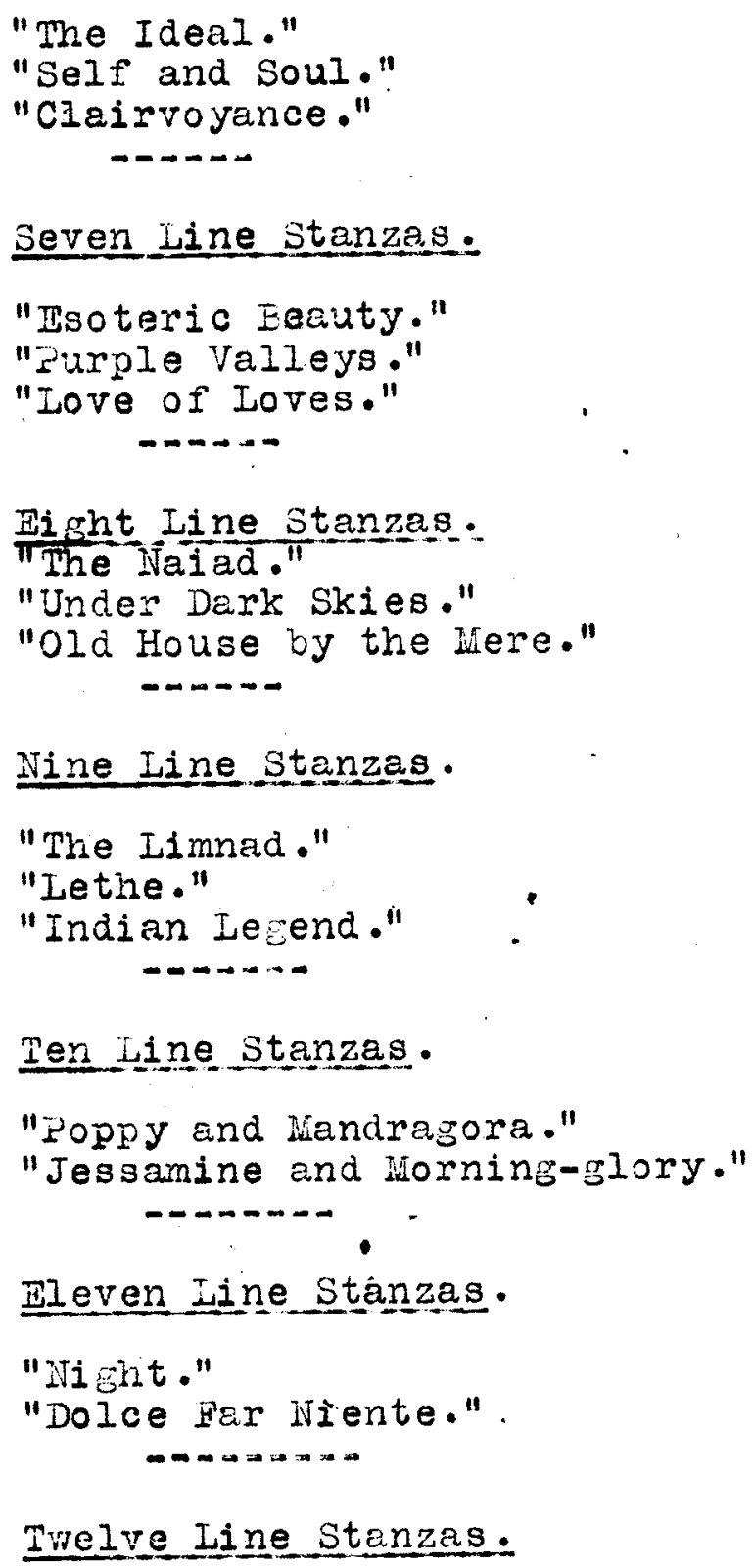

Twelve line Stanzas.

In the "Leaf Cricket" and other poems Cawein has used short metrical lines. This is characteristic of the stanzas of the lyrical poets of the first part of the seventeenth century.

\section{Thirteen ine Stanzas.}

$$
\text { "To Sorrow." }
$$

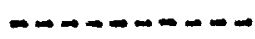

\section{iourteen Iine Stanzas.}

"Motive in Gold and Gray." 


\section{Lyrics.}

Some of Cawein's lyrics are highly musical, but quite often the theme is too romantic to have convincing value as "liignon," "Helen," "The Quest," and "Floridian." Our poet strikes the troubadour note in his lyrical love poems with a lightsome grace of phrase and fancy. He can, however, strike a deeper chord as in the poem called

$$
\text { "I do not lovie yoú now, }
$$

" shalio" soul wi th depths but to deceive!

You, whom mine watered; to whom yours did give

No drop to drink to help ry love.to live -

I" do not love you now.

\section{Sonnets.}

The somet is an Italian verse form in fourteen fivestress lines, introduced into England during the sixteenth century. Sonnets are divided into the Italian and Shakesperian sonnets. The sonnet was made glorious by Dante, Hichael Angelo, Tasso, Ariosto, and Petrarch.

Some of Cawein's sonnets are:

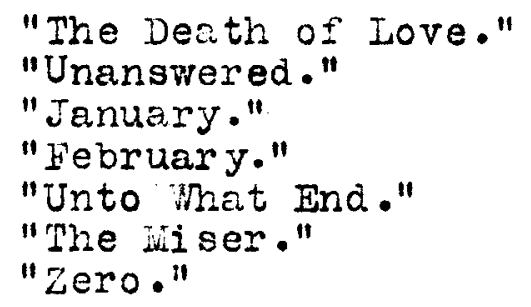

In his sonnet arrangement cawein follows the Italian metrique; the octave being based on two rhymes (abbaabba); and the sestet follows the rhyme scheme (cdecde.) 


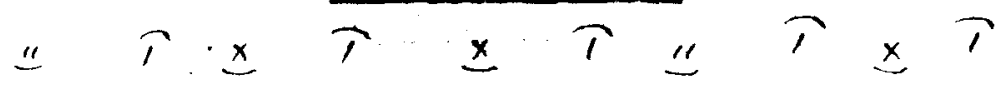

So Live is dead, the love we knew of old $T$ T And in the sorrow of our heart's hushed halls. $x T \pi \quad T \times \pi$

A lute lies broken and $\underset{x}{ }$ rose-fiower falls;

, 1 , $, \pi x, 1$

Love's house stands empty and his hearth lies cold.

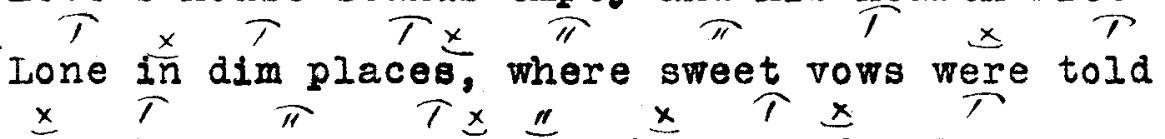

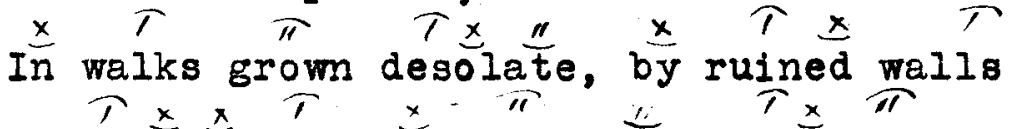

Beauty decays; and on their pedestals

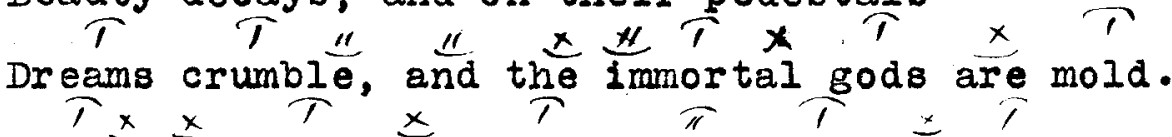

Music $\frac{x}{\pi}$ is slain or sleeps; one voige alone,

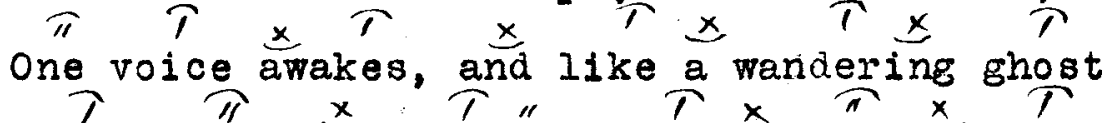

Haunts all the echoing chambers of the Past $\frac{x}{T} \underset{T}{T} \frac{x}{T}$ voice of memory, that stilis to stone

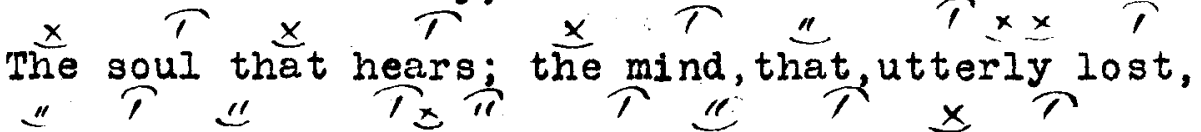
Before its beautiful presence stands aghast.

(cawein.)

Other forms of metrique; which are found in Cawein's poetry, are ballads, romances, and blank verse; and other characteristics are alliteration, medial rhymes, refrains, and tone qualities.

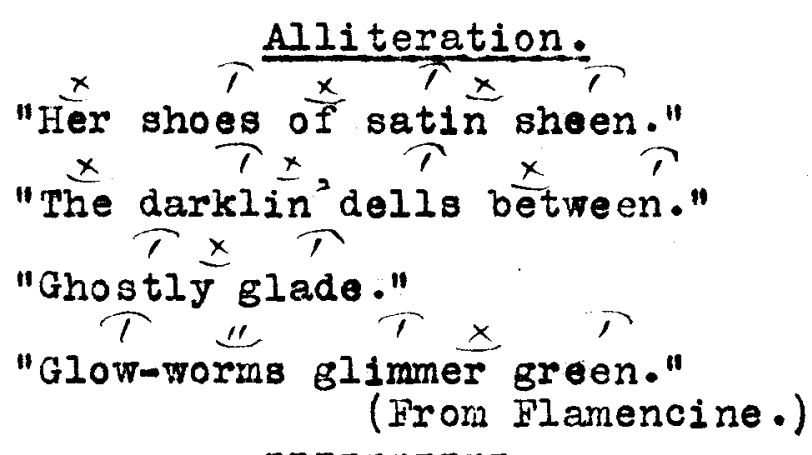

Medial Ryyme.

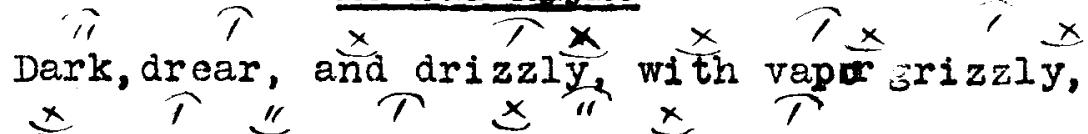
The day go"es dully unto $\frac{x}{i} \frac{x}{\pi}$ close;

Its wet rob̆e smuthces each thing it touches,

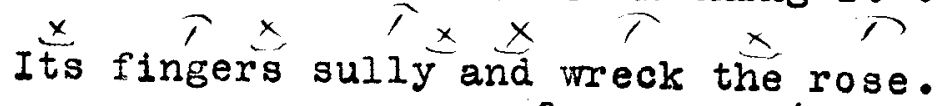


1. $\times \% \frac{\text { Refrains. }}{x} T$

And again $I$ looked behind

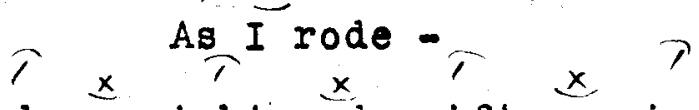

$\underset{T}{\operatorname{Dark}} \frac{x}{T}{ }_{x}$ night and swift $\frac{x}{T}$ wind,

Towering, $\frac{x}{T} \underset{T}{T}$ rode behind,

As I rode.

(Headless Horseman.)

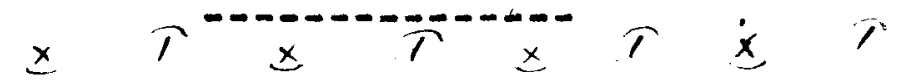

The rain hath sicklied day with haze, $\tau \times \pi$

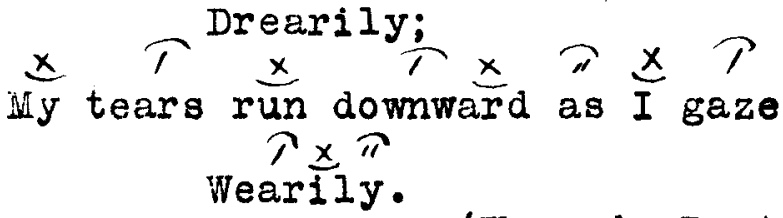

(Woman's Portion.)

\section{Tone Quality.}

The selection of sound has much to do with the melodious effect of poetry. The poet may choose different sound qualities just as a musician may choose the varying qualities of the different instruments in the orchestra.

Madison Cawein knows the true value of this element in poetry, for Nature has sung to him in every tone which her Aeolian harp can strike.

The following are examples of tone quality:

And the gleam of the dew on the fern's green tip

Was a sylvan passing with robe a-drip.

For the Wind clasped hands with the water's rush,

And I heard them whisper $\# T$

$$
\text { "Hush, oh hush!" }
$$

(Moon-Men.)

"I

"iNo spotted" serpent hisses near her shrine."

(Chryselephantine.) 


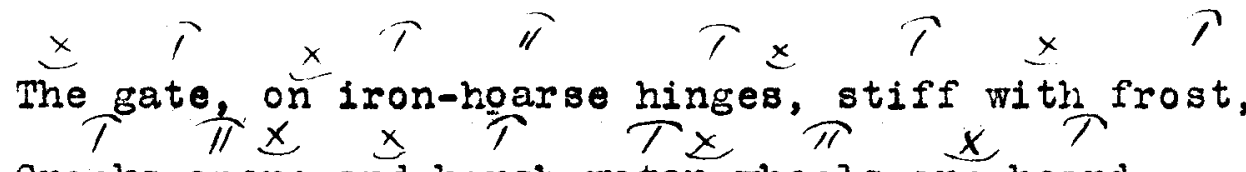
Croaks open; and hargh wagon-wheels are heard Creaking through cold.

(Zero Weather.)

\section{$\underline{\mathrm{C}} \underline{\mathrm{N}} \underline{\mathrm{C}} \mathrm{I} \underline{\mathrm{U}} \underline{\mathrm{I}} \underline{\mathrm{N}}$.}

In conclusion, I may state that cewein's poetry is opulent in metrical variety, carrying music in his lucid words, rhythm in his lines, often fitting emotional and poetic stress and dignity in his slow-moving, meditative verse. 
CAWEIN'S METRICAI ROMANCES AND IDYLIS.

Having studied Cawein's collection of poems called

"Old World Idylis," I am now prepared to treat the following

themes and shall amplify them with various selections from his poetry and from the poetry of other authors:

I. The Arthurian Cycle is the Source of Some of Cawein's Hetrical Romances and Idylls.

II. Cawein's Relationship to Other Arthurian Poets; the Early Writers Being:

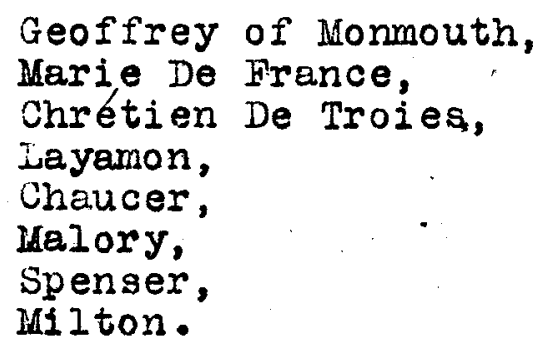

The Nineteenth Century Writers Being:

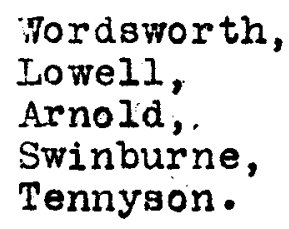


I. The Arthurian Cycle is the Source of Some of Carein's Metrical Romances and Idyils.

The Arthurian cycle of legends serve as a touchstone of romanticism, and many poets, who found a source in this rich, poetic mine, have not dug out the ore for themselves, but taking what their predecessors have given, they have moulded and polished it with their own individuality.

The stories of King Arthur are worthy of study for various reasons. For one, they were the favorite fiction of our mediaeval ancestors, surpassing in popularity the native French hero-tales which clustered around Charlemagne; the native Germanic hero-tales, of which the rnost famous are those of siegfried; and the literary tales invented during the later hiddle Ages about the fictitious Amadis of Gaul.

The Amadis romances are dead. The native French cycle is dead.* The old Germanic cycle, at least in Wagner's Nibelungen tetralogy, has waked recentiy to a new but rather uncertain life; but the Arthurian cycle, which in the eighteenth century seemed moribund, has in the nineteenth century cone ogt with the Iusty vigor of renewed youth.

In the last fifty years no Inglish narrative poem has been more liked than Tennyson's Idylls of the King; and no opera more popular than Lohengrin, the story of the Swan-Knight, sent from the Grail Castle to aid Ilsa of Brabant. Tristan und Isolde is generally counted one of the Ereatest music tragedies of the world; and Wagner's treatment of Parsifal and other Arthurian

*(Foot-note) I refer to the French and Germanic cycles as subjects for serious literature. In a popular way they are more alive than the Arthurian cycle. Siegfried is still the hero of many a German Volksouch. In Italian puppet - shows one nay still. see Roland's heroic strugbles against the Baracens. 
themes commands a large audience. Finally, the legend of the Holy Grail has of late given Mr. Abbey subjects for pictures which have been widely noticed in two continents.*

Thus we see the Arthurian stories are very much alive today, at least for the English race, both in the British Empire and in the American Republic; and Hedison Cawein, our Kentucky poet, found the Arthurian cycle a source for some of his metrical romances and idylls, as we shall see from selections from some of the following poems:

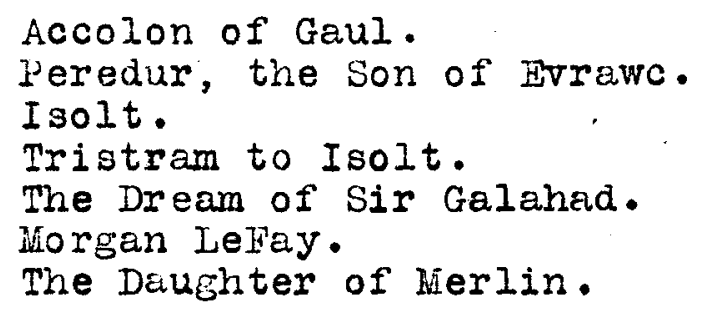




\section{Accolon of Gaul.}

Sir Accolon of Gaul was a brave knight of Arthur's court, who loved the king's beautiful and wicked sister, Morgan Le Fay.

Through her love for this knight and her treachery to the king, Accolon, without his knowledge, obtained possession of Arthur's sword, Excalibur.

Accolon fought with the king, who recovered Excalibur during the confliot, and mortally wounded the knight whose dead body was sent to Morgan Le Hay as a gift from King Arthur, the ironhusked flower of war. Meanwhile, Morgan Le Fay, thinking that Arthur would be slain, and hoping to crow Accolon of Gaul King of Arthur's realms and herself queen, slew her husband, trience in sleep.*

Cawein's metrical romance, fccolon of Gaul, contains about 1690 lines of iambic pentameter verse written in couplets. This is the best of Cawein's collection of poems called "old World Idyl1s."

After the prelude the story vegins with a love scene between the knight and liorgan LeFay.

"Again I hold thee to my heart, Morgane; Here where the restless forest hears the main Toss as in troubled sleep. Now hear me, sweet, While I that dream of yesternight repeat."

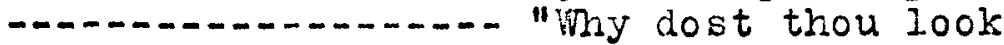
So serious? Nayl learn lightness from this brook, And Eladness from these flowers, my Accolon."

"still, thou art troubled, Morsane, anc the mood Deep in thy fathomless eyes glows. - Canst not keep Wine eyes from seeingl Dark thy thought and deep As that of some wild woman."

(Foot-note)* Here Cawein does not show fidelity to the old romances. According to Sir Thomas lialory, Sir Ewaine, son of Morgan Le Fay and Urience, stays the hand of his mother as she lifts the sword to slay her husband. 
The death of Six Accolon is well motivated in the next

few Iines:

With shadowy eyes Iong, long she gazed in his, Then whispered dreamily the one word, "Bliss." And like an echo on his scil mouth sate The answer: "BIiss?" - deep have we drunk of late? But death, I feel, some stealthy-footed death Draws near! whose claws will clutch away - whose breath? I dreamed last night, thou gather'dst flowers with me iairer than those of earth.

Then to charm away his gloom she sings this beautiful

little lyric of four stanzas:

Will love be less, when comes the sumner tell? Her throat a lily, lone and spiritual: When like a poppied swath, - hushed haunt of bees, Her form is laid in slumber on the leas, Will love be less?

Will love be less, when Winter at the door Shakes from groy locks the iclcles, long and hoar? When Death's eyes, hollow o'er his shoulder, dart Dark looks that wring with tears, then freeze the heart, Will love be leas?

Her beauty filled him with divine despair, Around his heart she seened to wrap her hair, Her raven hair, and drag him to his doom; Her looks were splendid daggers in the gloom of his sick soul his heart's invaded tower, Stabbing, yet never slaying, every hour.

\section{He felt no are}

When low she kneeled beside him, beautiful As some lone star and white, and said, "To luli Thy soul to sleep, 10, I have come to thee. Didst thou not call?"

The rnurder of Urience shows the dramatic touch of the poet.

The sword she took; and to the chamber, where King Urience slept, she glided. 
Iistened; and, sure he slept, stole in and stood Crouched o'er his couch. About her heart the blood Caught, strangling; then rose throbbing, thud on thud, Up to her wide-stretched eyes, and up and up, As wine might, whirling wildly in a cup.

So she stood pondering with the sword; her lips Breathless, and tight as were her finger tips About the weapon's hilt. And so she sighed, "Nay, nayl. too long hast lived who shouldst have died

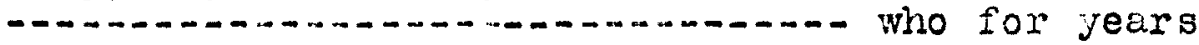

Hast bound iny life to thine, a bond of tears, A weight of care, a knot that thus I part'. Thus harshly severl. Ugly that thou art Into the elements naked!" O'er his heirt The long blade paused and - then descended hard. Unfleshed, she flung it by her murdered lord, And watched the blood spread darkly through the sheet, A drip, a horror, at impassive feet pooling the polished oak. -......................... in her ecstasy

A lovely devil; demon crowned, that cried For Accolon, with passion that defied Control in all her senses.

And while she stood revolving if her deed's Secret were safe, beholdl a noise of steeds, Arms, jingling stirrups, voices loud that cursed Fierce in the northern court. To her, athirst For him, her lover, war and power it spoke, Him victor and so king. And then awoke Desire to see and greet him: and she fled, Like some wild spectre, down the stairs; and red, Burst on a glare of links and glittering mail, That shrunk her eyes and made her senses quail. To her a bulk of iron, bearded fierce, Down from a steaming steed, into her ears, "This from the King, $O$ Queenl" laughed harsh and hoarse Two henchmen beckoned, who pitched sheer, with force, Loud clanging at her feet, hacked, hewn, and red, crusted with blood, a knight in armor-dead: Her Accolonl. flung in his battered arms By what to her seemed fiends and demon forms, Wild-torched, who mocked; then, with the parting scoff, "This from the king!" phantoms in fog rode off.

The artistic beauty of this poem, Accolon of Gaul, enriches the romance; the metrique, having the five rhythm waves of Tennyson's Idylls, is musical; and Cawein always knows the true value of Nature as a setting for his verse. In parts of this poem we find a happy blending of contemporary sentiment with old manner. and customs,..picturesqueness, gallantry and chivalry. 
Less modernism would make it too aloof from us; and less inediaevalism would take away the romantic picturesqueness. 


\section{PIARAOUR THE SOM OP TMAATC.}

Peredur, a knight of Arthur's court, loves Angharad, a maiden in attendance on queen Guinevere. Scorned by this girl, Farl Addanc besieges her castle, but Peredur comes to the rescue, and, with the consent of the queen, marries Angharad. Such is Cawein's romance of about 426 lines. According to Professor Rhys (Arthurian Legend ch.6) Peredur, the Welsh hero, and Lancelot were originally identical. The Peredur in Lady Guest's Mabinogion loved an indefinite "empress," who was coufounded by French romancers with Guinevere.

In Cawein's poem, after the first meeting of Peredur and Angharad, she sings a lyric asking him to forget her. The reply of the knight touches a deep human chord:

"Ayel that I will I thy face, thy form, thy voice, 0 bird of spring! whose beak is in my heart. Take out thy beak, and sing me back my soul 0 bird of spring," he said, "when flowers are dead Thy wing will winter underneath the pine, And hunger, for the summer that is gone, Will slay thy music with the memory. God give thou find no winter in thy heart When as dost find the frost invades thy roice; Ah, lovelier than thy song, there's that in me That harps and sings of thee; that troubadours Thy beauty ballades, sonnets it $/$ and makes A lyric of each heart-beat-all in vain. A To one who'd love thee over all belief Above all women and beyond all men."

After Peredur rescues Angharad from the iron claw of Addanc the tale ends happily.

"She loves mel Yea, she loves mel" and it seemed He heard her as men hear the voice of hope Upon despair's black brink; and see one star Bloom, like a lily with a heart of fire Throbbing within it, slowly out of night. Fach syllable the petal of a flower A rose of music, welcome as a star, The first the eve gives silvery utterance to; -138 - 
Or as the firsting bud, the wildrood rose, Dropped from the rosy lips of laughing Spring. 


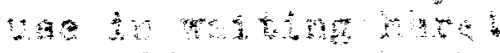

Ioelt.

The Tristram and Inewt legend; the last of the chief Arthurian romances, is dith itsorerpomering, passionate love, and its wild, sea-washed Celtic lands, the most poetic of them all. The eaxliest extant Tribtrom narratdre is from the pen of an Anglo-Nortian, Beroul, who wote during the twelfth century.

Tristram, nephew to King Mark of Cornwall who chose for his queen the beautiful Princess Iseult of Ireland, was sent by the King to escort her to Brittany. Iseult married King Mark but loved Tristram, and out of their undying love grew this mediaeval romance.

Upon the following excerpt from Sir Thomas Malory's

Lelorte d'Arthure Cawein wite his poem Isolt, wailing the wild passionate grief of Isolt at the death of Tristram:

"But when the queen, La beale Isoude heard these tidings shee made such sorrow that shee ras full nigh: out of her minde, and so upon a day shee thought to olay herselfe, and nerer for tolite ofter Sir Iristram's death." - Le Morte d'Arthure.

\section{Isolt.}

And reaching out her arms she cried:

"O Godl O God that I had died!

- Tristram Iristraml art thou near?

- love, be near me in this hourl

This hour of anguish and of fear!

Which - (like yon fountain's ceaseless foam,

Unseen, beneath this starlit tower,

Deep in the shadow of its dome)

Throbs on and on within my life,

The utter darkness of its woo;

0 hour of grief! 0 hour of strife!

Why rnust my young heart suffer so?

Why must my sick soul sigh and sigh,

And God not hear nor let me die?"

When rose the moon, and far away

A nightingale beneath the tower,

Heard through the fountain's falling spray,

Wade lonelier yet that lonely hour;

And 'twixt the nodding grove and lake

A glimmering fam stalked through the night,

And snuffed the wind, then bent to slake

Its thirst; she veiled her face,- as white 
As death's, and said: "The way is cleart

There is no ues in waiting herel

Comel let me cure this heart that bursts

Comel let to still this boul that thirsts!

Upon tho lake as thick as otars

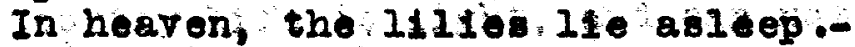

Here lies way beyond these bars,

These walls of flesh that hold and keepl

The nightingale shall find its mate,

The fam its follow, and must I,

The spouse of gitef, the wife of hate,

Iise on alone until I die?

How long, how long, 0 God to wait!"

Far through the darkness wont her ory.

From these elosing lines of Carein's poem wo see that the poet followg the old romance with good deal of fidelfty, that La beale Isoude "thought to slay herselfe."

Matthew Arnold's tragedy of Iseult, who stifles from necessity the longings of her heart and struggles on amid unsympathetic onvironment, is a form of suffering more acute now than in the less introspective uldale Ages. Wi th it naturally goes more self-control than the Iseult of old ever had.

Contrast Cawoin's wIId, grief-impassioned Isolt, who is more mediaval, th Arnold's Iseult suffering for her love in a cool, self-controlled, nineteenth centuny way. 


\section{Iseult.}

Altered, Tristram? Not in courts, Delieve me, Love like mine is altered in the breast:

Courtly life is Ilght, and can not reach it;

Ahl it lives, because so deep-suppressed.

What 1 thou think'st men speak in courtly chambers

Words by which the wretched are consoled?

What ! thou thinkst this aching brow was cooler,

Circled, Tristrarn, by a band of gold?

Hush, no words! that smile I see forgives me.

I am now thy nurge, I bid thee sleep.

Close thine eyes: this flooding moonlight blinds them. Nay, all's well againl thou must, not weep.

\section{Tristram.}

I am happy b yet I feel there's something Swezls my heart, and takes my breath away. Through a mist I see thee; near come nearer! Bend-bend down! I yet have much to say.

I am dying. Start not, nor look wildlyb Me, thy living friend, thou canst not save. But, since living we were ununited, Go not far, 0 Iseult! from my grave.

Now to sail the seas of death I leave thee one last kiss upon the living shore.

\section{Iseult.}

Tristraml Tristram! stay-recelve me with the Iseult leaves thee, Tristraml nevermore. (Mat thew Arnold.)

Swinburne's story of Tristrarn of Lyonesse begins on that fatal day when Tristram and Isoult, sailing by the cornish coast, drank the love potion from the flask which Brangwain had carefully guarded. 
Their hodde noarod, and their handowere drain in one, And thoy saw dark, though stly tho unsunken sun

Iax through fine roin shot fire into the south.

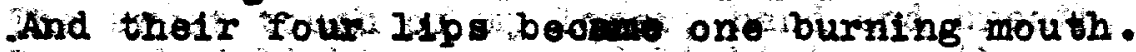

Henoeforth the two aro hold in ohadno of lore till death.

In depicting this love; Swinburne is not essentially different in spirit from Gottfried ron Strassburg and other medieeval romancers. Each of his lovers, like theirs, is ready for self-sacrifice, so the other be helped, as Iseult shows in her prayer when she keeps lonely vigil at Tintagel.

Nay, Lord, I pray thee let him love not me, Iove me not anj more, nor like no die, And be no more than such a thing as. I. Iurn his heart from mo, lest my lore too 2080 Thee as I lose thee, and his fair soul refuse For my bake thy fasi heavon, and as I fell Fall, and be mixed with my soul and with hell. Let me die rather, and only; let me be Hated of him so he be loved of thee, Iord: for I would not have him with me there out of thy light and love in the unlit air, Out of thy sight in the unseen hell where I Go gladly, going alone, so thou on high Iift up his soul and love him.

In Swinburne's presentation of the story, comes almost directly the passion which is more emphasized than the unselfishness of the lovers. None of his mediaeval masters made it stronger.

Yea, since I surely loved him and he sinned Surely, though not as my sin his be black, God, give him to me - God, God, give him back! For now how should we live in twain or die? 
I am ho nded, thou knowert and ho is I. Not man ân woman Boveral as we were, But one thing th one life and death to bear. How should one love his ow soul overmuch? And time io long sipoe last I felt the touch, The sweet touch of my lover, hand and breath, In ouch delight put delight to death, Burn my soul through.

Bost thau fool, thou, this beartboat whence my heart Would send thee word what life is mine apart, And know by keen pesponse what if ife is thine? Dost thou not hear one cry of all of mine? Q Iristran's heart, have I no part in thee?

Mediseval thus, Swinburne yet has his modern side, as we should expect of an author of the ninoteonth century. Ifle Morria, he trias far moxe than mediaeval writers to get at the motives of his characters, be lay bare the thoughts and tions ohich thoir grost love ingpires. In fact, he analyses this love too much; and ho is of his ow time, too, in his marrelous technique, in tho eagy gteady flow of his beatiful verse. This fluenoy and fondness for anolysis and mediaeval pictures become faults. 


\section{Wéner stotan und Isolde.}

From dramatic necessity Vagnor has selected for his

three acts three incidents wioh he thought most significant in the adventures of his lovers.. Two of these were the drinking of the love potion and the death of the lovers. It was less easy to choose a dramatic third for we know that the mediaeval writers gave Tristram and Iseult many sweet meetings, when they narrowly escaped detection, and many adventurous partings, which each feared might be final.

\section{Wagner, wth oure, dramatic instinct, chose a meeting} which was typical of all, and yet marked a crisis: that one when King Nark surpri sod his queen and Tristram together, having told his knights that he was going to the hunt, but in reallty was spying near his palace.

Two considerable changes Vagher made in the ineidents of the legend. He states clearly mat nedlaeval writers only hint at, that the potion io after all but symbolieal of the love which, against thelr H1l1, has sprung up between Trlotram and Iseult. The following selection is taken from Act II of the opera where both sing with rapture to the Wagnerian music.

\section{Belae.}

Bist du mein?

Habl $1 \mathrm{ch}$ dich neder?

Darf lch-dlch fassen?

Kann ich mir trauen?

Fndlichl Bndlichl

An melner Brust!

Fuhl ich dich wirklich?

Bist due es selbst?

Dies deine Augen?

Dies dein Kund?

Hil er dein Herz?

Bin ich's? Bist du"s?

Helt' ich alch fert?

Ist es kein Traum?

0 Wonne der Seelet

o susse, hehrate

Kuknste, schonste 
Seligste Lustl

Ohne Glelchel

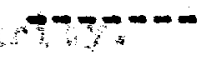

\section{Tennyson's Isolt.}

The Tristram and Isolt of Tennyson in "The Last Tournament" show degeneration, and they appear nowhere so petty and selfish in their love and nowhere do they die more ignobly. The following selection shows the petty selfishness of the lovers as compared with the self-aacrificing love of those of Swinburnes

Then Tristram, ever dallying with her hand, "May God be with thee, sweet, when old and gray And past desirel" a saying that angered her. " IMay God be with thee, sweet, when thou art old And sweet nor more to mel' I need him now For when had Lancelot uttered aught so gross Even to the swinoherd's malkin in the mast? The greater man, the greater courtesy. Far other was the Triatram, Arthur's knight But thou, thro' ever harrying thy wild beasts Save that to touch a harp, tilt with a lance Becomes the well - art grown wild beast thyself. How darest thou, if Iover, push me even In fancy from thy side, and set me far In the gray distance, half a life away. Flatter me rather, seeing me so weak, Broken with Mark and hate and solitude, Thy marriage and mine own, that I should suck Lies like sweet wines: I1e to me: I believe: Will ye not lie: Swear to me thou wilt love me even when old Gray-haired, and past desire, and in despair."

Then Tristram, pacing moodily up and down, "Vowsl did you keep the vow you made to Mark More than I mine? Iied, say yet? Nay, but learnt The vow that binds too strictly snaps itself My knighthood taught me this - ay, being snapt We run more counter to the soul thereof Than had we never sworn: I swear no more."

Here Tennyson presents the human frailties of Tristram and Isolt, and in consecutive narrative of the Idylls he emphasizes the steady, pitiless growth of corruption at Arthur's court; although the tale of Gareth, a sweet idyll of youth, shows $-147-$ 
court life stidi in its purity.

$-148-$ 


\section{The Dream of Sir Galahad.}

This peem of cawein has thirteen six-ine stanzas. Sir Galahad is sitting in a chapel in Lyonesse with the knights Peredur and Gawain, telling his dream while the dawn slowly reddens on the sea, gray-seen through the open door. In his dream three angels appeared to him, and his soul, clad in glory soared with them, who sang,

"Christ awaits theo, Galahad."

Cast on sleep there came to me Three great angels, o'or the sea Moaning near the priory:

cloudy clad in awful whito,

Hach one's face, a Iucid light, Rayed and blossoned out of night.

And I saw their mouths were fire, Ruby-red as the desire of the sanc Graal f fair and dire Were their lips, whereon the kiss of all heaven lay, the bliss

of all happiness that is.

Grew my soul with light: that saw The embodiment of awe, Love, divinity, and Iar Orbed and coned: and the power, Circumstance, like some vast flower; From which time fell, hour and hour.

To my lips her lips she pressed; And my new-born soul, thrice-blessed, Clasped trer radrance and oaressed: Hounted and in glory clad, Soared with them who chorused glad: "Christ awalts thee, Galahad!" 
We owe the earliest extant form of this mystical legend of the Holy Grail to Chretien de Troies of the twelfth century. He is said to have written his Perceval or Conte dral Gral the request of Count Philip of Flanders.

Perceval was the heyo of the Grail story, but Chretien died, leaving an unfinished poem of 10,601 lines, to which another poet named Gautier added 20,000 more lines, and Nanessier concluded it, making a sum total of 45,000 lines.

Still another author, Gerbert, wrote another conclusion of 15,000 verses, thus making the conte du: Graal, with these additions and the interpolations to them, a rambling metrical romance of over 63,000 Iines.

In Chretien's account of the Grail, the earliest we have, nothing definite is said of its sacred Christian character. With Chretien's continuators, the nature of vessel changes and it becomes an object of Christian significance; and the lance and the sword which accompany it are made holy objects by Gautier who says that the lance pierced the side of the Son of God.*

Later on, we learn that the Grail caught the blood from Christ's wounds on the day he was crucified: *

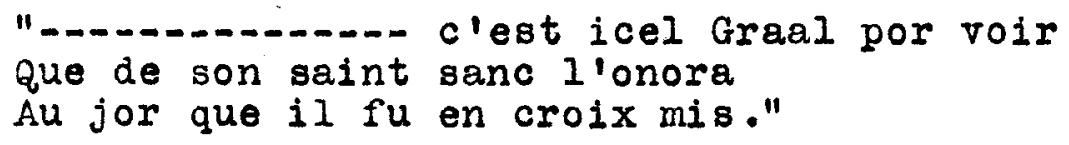

(Foot-note) * Cf. John XIX, 34, "But one of the soldiers with a spear pierced his side, and forthwith came there out blood and water." 
It is probable that Gautier's explanation of the sanctity of the Grail was not his, but an interpolation made after Robert de Boron wote his poema on the Grail. It is likely, then, that Robert de Boron, and not Gautier, first gave the Grail Christian significance. However, it is certein that Boron was the first to attach the fully developed legend of the Grail to the Arthurian cycle.

Boron wote a trilogy - Joseph q'Armiathie, Merlin and Perceval. The Joseph makes the vessel sacred for it was used by Christ himself at the Iast Supper; and afterwards a soldier of Pontius Pilate, Joseph of Arimathea, * who loved Christ and took His body down from the cross, caught Hils holy blood in it when the wounds began to bleed afresh. Boron's Joseph is concerned chiefly with showing how the Grail was carried to Britain.

The quest of the Holy Grail, or quete du St. Graal, is another prose romance whose authorship is undetermined. In the Quest a new character appears, Sir Galahad, and Perceval is no longer the hero. It foretell that Galahad, the virgin knight, shall be keeper of the Grail.

This form of the story the later poets used in metrical composition; and Cawein makes Sir Galahad the pure knight of the Grail story.

(Foot-note) * The Gospels give no hint of Joseph's being a soldier, According to llatther, he was "a rich man of Arimathea, -- who also himself was Jesus! disciple:" according to Luke, "A counsellor A good man and a just.". 


\section{Morgan Le Fay.}

This poem by Cawein has fifteen stanzas; and, following his story, Morgan Le Fay, enchantress and sister of King Arthur, tempts Sir kay by her witchine beauty, and finally leads him to a castle where she pronounces her curse upon him. Here Arthur's Knights rise as once and pierce his body with their swords.

\section{Morgan LeFay.}

In dim samite was she bedight,

on her hair a hoop of gold,

like foxfire, in a tawn moonlight, Was glimmering cold.

"Oh, come with mel on, come with mes Oh, come with me, my love, Sir Kayl" How should he know the witch, I trow, Mörgearar Le liay?

Hicw should be know the wily witch, With sweet white face and raven hair? Who through her art, bewitched his heart And held him there.

Eftsoons, his soul had wexed amort To wold and weald, to slade and stream; find all he heard was her soft word As one adream.

Then from Sir Kay she drew away, And cried on high all mockingly: "Behold, sir knights, the knave I bring,

Upan him, yea, there rests my curse: Now let him die!"

And on his body, bent and bowed, The hundred blades as one blade fell: While over all rang long and loud The mirth of hell. 
Morgan Le Fay* figures in the romance entitied "Sir Gawain and the Green Knight of Irigh origin and witten by an unknown autbor between 1350 and 7375 .

The Green Knight appears at Arthur's Court through the enchantment and machinations of the king's malicious aister, Morgan Le Fay, who had sent him thither to terrify Guinevere. We find at times, as in the fourth stanza quoted, that Cawein, like Scott, has well imitated the language of mediaeval romance. originally not a lady of the lake, as in Malory, but the daughter of a nobleman, Dionas. Merlin taught her necromancy. There is no doubt she was origlnally a fairy. Prof. R.H.Y.S. Identifies her with Morgan Le Fay. 


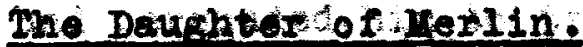

Amid the mountain's hoasse call and the dash of the

wid cataracts, the Daughter of Herlin appears to the poet as a chadoin and says:

"Iol You must follov

And our path 18 o'er myriads of graves."

Together they climb higher and higher until they enter the starry gummit of light and musie.

\begin{abstract}
As we clomb - till the limbo of spirita
of lusts and of sorrows below Swung nebular; and we were near its

Starred summit, 1 ts glory of glow. And we entered its 1 lght and could hear its White music of silence and show
\end{abstract}

If we whin to allegorize Cawein's paem we may look upon the Daughter of Meriln as typifying perfection of human science, thus paralleling Cawein's idea with that of Tennyson, who gave his sanction to articles in the Contemporary Review for January 1870 and May 1873 in which he admitted that lierlin typified intellect.

The earliest story of Merlin in close connection with Arthur appears as far back as the time of Nennius, a Wolsh monk who lived about the year 800 . He tells of a boy of marvelous birth, whose name was Ambrosius, and according to Geoffrey, Ambrosius Merlin, and later simply Merlin. According to the Merlin of Robert de Boron, Uther Pendragon, Arthur's father, established the Round Table by the advice of this sage, in cormemoration of the table of the last Supper.

Later, Merlin became enamoured of Vivien, the damosel of the lake, who wove about him spells, which, through her 
blandishments, she had por gadod hin to tesch her. After that Merlin was seen no more.

Merlin appear in Spenserts Faerie queen a a great sage who 21 ved at King Ryencels court in South Feles, instead of at Arthur's. Again we find his name in Scott's Bridal of Triermain and in Tennyson!s Idylls.

Cther poems in Cawein's collection of old world Idylls are:

$$
\begin{aligned}
& \text { After the Tournament, } \\
& \text { The Forester, } \\
& \text { An old Tale Retold, } \\
& \text { The Knigh-Frrant, } \\
& \text { A Princess of Thule, } \\
& \text { Tho Rosl crueian. }
\end{aligned}
$$

The Rosicrucian 18 a visionary alchemist who, through his magtc art, creates a sylph born of his own soul.

Cawein also throws the flashlight of his genius upon

life in the orient in The Slave,

The Khalif and the Arab, Arabah, The Seven Devils, a legend of Hohammed, Behram and Bdetma, etc. 


\section{Geoffrey of Monmouth.}

Geoffrey of Monmouth, though not a poet but a historian, whose chronicles are the first extensive literary treatment of some of the Arthurian stories, was the first to give them literary dignity and consideration which they had not enjoyed before. This witer was born towards the close of the eleventh century. His Historia Regnum Britanniae, which appeared about 1137, Is a chronicle of the British kings * from "Brute, the first King of the Britons," down to a period later than the Saxon conquest.

When Geoffrey comes to the reigns of Uther Pendragon and his son Arthur, his history grows more circumstantial than either before or afterwards.

Geoffrey's Prophecies of Nerlin is a work in Latin and the Vita Merlini is a Latin poem in which Arthurian characters appear.

Here we may state that Geoffrey has a remote influence upon our nineteenth and twentieth century poets, who have taken mediaeval themes as subjects of their poetry. Within a century of Geoffrey's death, lais, metrical romances, and prose romances had helped to establish these legends in their exalted position and to spread knowledge of them far and wide.

Nearly all the lais extant in French are in octosyllabic couplets, and love and knightly adventure, with magic, are the usual subjects. Marie de France wrote the best lais. Lanval

(Foot-note) * Hany storios now took literary form for the first time which have given material to poets ever since. The story of King Lear, for instance, and his three daughters is told with considerable detail. 
is one in which Arthur and Gawain figure, and Chievrefoil is another in which Tristram and Iseult fifiro. 


\section{Chretien de Troles.}

Chretien de Trotos, the most gifted and most famous French writers of the Round Table romances, is the earliest whose work has survived in anything but fragmentary form. Chretien wrote six Arthurian poems. The first was the story of Tristram, composed about 1160 , and though it has been lost, it is the surmised source of a later prose romance from which Malory drew material for his Tristram.

His next Arthwrian story was Bric and mide, best known today through Tennyson's Geraint and Enid. About 1170 Chretfen wrote Lechevalier de la Charrette, which tella of the loves of Lancelot and Guinevere; and his last Arthurian poem was Perceval, or Le Conte duc Graal, which he left unfinished, and which gives us the first literary mention of the Holy Grall. 


\section{Layemon}

After having taken definito shape in French, the Arthurian legends speedily found their way Into German, English, Spanish, Italsan, Scandinavian and Duteh.

Layamon, the first Arthurian poet writing in English, wrote his Brut about 1200 . He made three important contributions to the legends. He gave a circumstantial account of the founding of the Round Table; he gave a more detailed account than the earlier writers of the departure of Arthur for Avalon; and he made Arthur, who had already changed from a British chleftain to a French Anglo-Norman king, into a king with a good deal of English blood in him.

Chaucer unfortunately tells none of the Arthurian stories; they did not seem to attract him. He places the scene of the Wife of Bath's Tale at Arthur's court, but for the sole reason, apparently, of giving the tale a picturesque background. In Sir Thopas he mentions Sir Libeaus, the son of Sir Garain, and Sir Perceval. In the Nonnes Preestes Tale his reference to Lancelot shows that Chaucer knew this knight as the beau ideal courtiy lover.

"This storie is also trewe, I undertake, As is the book of Launcelot de Lake That women holde in ful gret reverence." Again in the Squieres Tale:

"Who coude telle yor the forme of daunces, So uncouthe and so fresshe contenannces, Swich subtil loking and dissimulinges For drede of jalouse mennes aperceyvings? No man but Launcelot, and he is deed."

We may surmise that Chaucer had no high opinion of Lancelot, but his reference to Gawain is truly appreciative. 
"That Gawain heth his lde curteisye, Though he were come ageyn out of Fairye Ne coude him not amende' with a wosd."

W1 th this $1 d 68$ of Gawaing it is a pity that Chaucer, the greatest poot of his age, dia not gee fit to make him the hero of Canterbury Talo. 


\section{Olr tromal tálory.}

Sit Thofies Halory was born about 1400 . Very little definte information 18 known conerhing his life; but his prineipal work, Morte Darthur, concerns ub. Fortunately for English literature, Malory lived at a time when the Arthurian stories were very popular in England, and he produced about the middle of the fifteenth century his Morte Darthur. His principal sources were the French Herlin, Tristram, and Lancelot romances in prose (the last including the stories of the Grail, Elaine of Astolat, and of Arthur's death), the English alliterative Morte Arthure, and Le Morte Arthur in English octosyllabic verse.

Malory was original in emphasizing Arthur as the central figure of his tale.

Walory, at the end of the line of mediaeval romancers, was near enough to our own time to make the Fngland of his Arthur something like the Ingland we know. In reading Malory we feel that vividness is a distinguishing quality of his style; and his Morte Dathur is filled with distinct little pictures such as the following:
"Now speak we of Sir I ancelot du Lake that lieth under the apple tree sleeping.
Even about noon there came by him four queens of great estatel and, for the heat of the sun should not annoy them, there rode four knights about them and bare a cloth of green silk on four spears, betwixt them and the sun, and the queens rode on four white mules." (Book 6, Ch. 3).
"Queen Guenerer let make hergelf a nun, and wore white clothes and black, and lived in fastings, prayers, and alms-deeds." (Book 21, Ch. 77).

With all their external reality; Malory's characters are only partially alive, for Nalory had but little psychological interest in them and but little invention. Accepting his people as he found them, he did not develop them further; but $-167-$ 
to Malory the modern poets owe a great debt. Tennyson, Arnold, Swinburne and many other poets found his Morte Darthur a source from which they derived material. As a preface to Isolt, Madison Cawein quotes from Maloryis Morte Derthur, thus showing the influence of this great Arthurian romancer. 


\section{Fimund Spenser.}

Spenser is remarkable as one of the moat inventive of our Inglish poets, for he created his own poetic language and a stanza of unusual beauty. During 1590 appeared the first three books of the Faerie queene, and in 1596 appeared the fourth, fifth and sixth. In the Faerie queene we find the influence of the Arthurian legends, which Spenser knew through Malory; and the first quest in the Faerie queen is strongly reminiscent of the Arthurian quest. Spenser shows a free treatment of the old romances. He does not try to tell the old stories at all, or to reproduce the old characters; but his aim is to make up a new story, for which he draws material from all possible sources. Mr. Maccallum * malntains that Spenser made so little use of the old knights because they were not suited for his personifial vices and virtues. The reason is rather to be found in Spenser's extreme catholicity of and exuberance of imagination. Gawain would have served as well as Callidor for the knight of courtesy; and Gallahad would have made an excellent knight of Chastity; had Spenser wished it; but it served his purpose better to make his knight of Chastity Britomart, a woman, that he might pay a compliment to Elizabeth, the Virgin queen. He regarded these old stories as a rich storehouse from which he might select at will ornaments for his new poem. Still he does show fidelity in one respect. The Faerie queene is full of the old romantic tone, and of such supernaturel machinery as we find in mediaeval Arthurian tales.

(Foot-note) * Tennyson's Idyils and Arthurian Story P.132. 
Spenser, then, etands primarily for the change from the mediaeval spirit to the modern in the history of the Round Table romances. 


\section{John Milton.}

The next great Inglish poot who was lafluenced by the stories of Arthur was John Hiltonone seams to have been attracted to them by tho faerio queen, mich be admired, and by, Halory's Morte Darthur, and Geoffrey's Higtory. In Paradise Lost, in recalling famous wartors, whose forces united would not have equallod Satanti, he saysi

n. - - - -

In fable or romance of Uther's son, Begirt with Britioh and farmorle enights."

(Book 1, IIne 579).

Again in Pâradise Regained; he speaks

"Of faery amels met in forent wide

By knights of Logres, or of Lyones,

Lancelot, or Pelieas, or Pellenore."

(Book 2 ; Hine 359).

It would be hard to find two references more sensitive to the beautiful poetry of tho old romances. No wonder scott * expressed his well-known regret that Milton did not write an Arthurian epic. Many critics have believed that Milton was wise in not writing an Arthurian epic as well as Paradise Iost. Others regret with scott that Milton's genius did not produce such a poem.

Whether or not the Milton of later days was too much of a Euritan to give his whole heart to it, the Milton of Comus would have treated the theme grandly.

(Foot-note) * Scott's Dryden, Introduction to King Arthur. 


\section{Wordsworth.}

Skipping over an age of prose and reason, during which Dryden wrote a dramatic opera entitled "King Arthur for the Glorification of charles II,"we come to an awakening of the old themes in the nineteenth centiury by Wordsworth, Lowell, Arnold, Tennyson, and Swinburne. Wordsworth's Egyptian Maid takes the form of a clumsy moral. Because the Egyptian kaid, who is a princess, personifies purity, she is the destined bride of Gallahad who is the purest knight of the Round Table. In thus marrying off this ascetic mediaeval celibate, Wordsworth is modern with a vengenace. Such a fundamental change one would expect in the age of prose and reason rather than in Wordsworth's. That Wordsworth had tho right foeling for the Arthurian stories he proved early as 1800 in lines of exquisite beauty, comparing a stately fern on the beach of Gramere to the

\section{"Lady of the Mere,} Sole-sitting by the shores of old romance." 


\section{Jamer Russelz Lorelz.}

James Russell Lowell in the Vision of Sir Launfal is the least successful in combining the ald romances with the new thought. Iike Wordsworth in the egptian Maid, Ioweli has exaggerated the moral that he wished to teach; and as his ow note on Sir Iaunfal explains, he has virtually rejected all the old material and invented a new incident, which may be termed Arthurian only 80 far as the Grail, that sacred quest of Arthur's knights, is sought by the hero of Lowelt a poem,

\section{Ionell says:}

"The plot (if I may give that name to anything so slight) of the poem is my om, and, to serve its purpose, I have enlarged the circle of competition in search of the miraculous cup in such a manner as to include, not only other persons than the herges of the Round Table, but also a period of time subsequent to the date of King Arthur'a reign."

To his newly invented Grail-quester, Lowell has given the name of Launfal, a name which comes indirectly from Marie de France's Lanval. Thus we see that, in his incidents, Ioweli is anachronistic. He has kept, however, to the best spirit of the Grall story, and so constructed a poem of which one sees the faults more clearly as time passes, but of which the sweetness will never die.

In his vision, while riding from his castle gate, Sir Launfal lightly tosses a coin to a leper who crouches at the gate begging for alms. The leper tells him that gold, given from sense of duty wi thout sympathy, is no alms at all. Sir Iaunfal rides the world over seeking the Holy Grail which he never finds. 
At last as an ald man he returng to his castle and there finds another leper more loathsome than before, again begging for alms. Sir launfal, remembering with regret how haughty he had been to the flrst leper, felt

"The heart within him ashes and dust;

He parted in twain his single crust,

He broke the ice on the streamlet's brink, And gave the leper to eat and drink;

t Twas a mouldy crust of coarso brown bread,

'Twas water out of a wooden bowl, -

Yet with fine wheaten bread was the leper fod, And 'twas red wine he drank with his thirsty soul."

The leper, transfigured in the image of Christ, odid to Sir Launfal that the Holy Grail was there in that vessel whtch he had just filled at the brook; for to him only might the Grail appear who knew true charity.

The reproaches which critics have brought against this poem are not undeserved. The introductions do not really introduce; the castle in the north of fingland is surrounded by a New Pngland country; and the famous day in June is all New England June; yet with all its faults, the poam teaches a losson which touches the hearts of men; and Lowell makes the owestness of it go far towards disarming unfavorable criticism. 


\section{Arnold and Srinburne.}

Mat thew Arnold' Tristiram and Isoult, which has been previously discussed In connection with Cáwein's Isolt ceeps the facts of the old gtory, except for efow ohanges, but two of these are radical. He makes Iseult arrive at Tristram's sick-bed just before lnstead of just aftor his death - a change which the deeper sympathy of the nineteenth century should bring about, for it seemed a cruel fate which forbade the lovers even one last word. The other important change is that he gives Iseult of Brittany two children, and he endows his characters wi th nineteenth century feelings.

Nevertheless in reading Tristram and Iseult wo do not lose the charm of the Middle Ages. Hence we may say that Arnold's Tristram and Iseult shows half-way mediaevalism.

Swinburne's Tristram of Lyonesse, also previously discussed, has its modern side as well as modiaeval. He is psychological in his analysis; but as hir. Andrew Lang says this poem "merely showed that among Mr. Swinburne's many gifts the gift of narrative is not one. The story is clogged by the heavy splendor of the style." *.

The Tale of Balen is a better narrative than Tristram of Iyonesse, though inferior in poetic imagery; and this story of the two brothers and their mutual slaughter, neither recognising the other, is one of the best in Malory's Morte Darthur, and Swinburne has done wisely to modernise it but little. In (Foot-note) * Dr. Sommer's Edition of Morte Darthur Vol. 3, P. 24 . 
consequence, his version is better than Tennyson's in the.Idyllo. Iennyson puts too much moral into the old talo and makes Balen a victim of his ow violent nature, while Malory and swinburne make him the victim of fate. At the close of the tragedy Balan and Balen died -

And there wh morning Merlin came, And on the tomb that told their fame He wrote by Balan's Balents name, And gazed thereon and wept.

(Swinburne) 


\section{Tennyson.}

Whether or not the world will deem the Idylls of the King Tennyson's most important work, they are his life work. If we look upon the allegorical unity of the Idylls, Arthur represents the soul, the spiritual ideal, which is always warring with sense. Arthur, in slaying beast, driving out the beathen and suppressing robbers, io not only the just king of the romantic chroniclers, but man's spiritual ideal overcoming base passions. In the last scene, Arthur, in talking to Guinevere, is really Soul explaining jts failure in the war with sense.

Tennyson's teaching that the soul sees its best visions and gets glimpses of the Grail, not in unpractical ascetic quests, but by working among men is like Loweli's moral in Sir Launfal and Wolfram's in Parzival.

We see a blending of the old and new in the setting of the Idylls, a pleasant English country, both mediaeval and modern. In fact, the whole poem is a happy blending of contemporary sentiment with old manners and customs, picturesqueness, gallantry and chivalry.

Critics have called the Idylls the noblest Bnglish blank verse since Milton. Tennyson has adapted the legends to modern times with such a genius that we may well believe many a day will pass before any poet attempts again to tell in English the whole long story. Tennyson is the only one of our greater English poets, who has treated the Arthurian legends adaquately. 


\section{$\underline{\mathrm{C}} \mathrm{O} \underline{\mathrm{N}} \mathrm{C}$ I U $\mathrm{S} I \mathrm{I} \underline{\mathrm{N}}$}

Having thus taken a kodak vier of some of the works of the Arthurian poets, we may state that Cawein's relationship to them is as follows:

(1) From the earlier writerg he received Inspiration; and knowledge of their workd, especially Malory's, awakened in him the true romantic spirit of mediaeral days.

(2) Like the Nineteenth Century Poots, he blends the old spirit of romance and chivalry with some psychic analysis and modern sympathy and feeling. 
CAWEIN'S BATHADS BEAL SPRCIFIC MARKS OF OLD FHGLISH AND SCOTCH BATLADRY.

Wuch do we regret that Madison cawein has not writton more ballads, for his poetry seems to have the true romantic spirit of old balladry, and his lyric narratives hold attention to the story in simplo rhythm.

We shall now consider his ballads wi th the old Engligh and scotch ballads under the two following topics:

I Some Characteristics of the Technique of OId Balladry:

1. The Bailad has Choral Origin.

2. Refrain and Incremental Repetition.

3. Popular Hotif of 0ld Ballads.

4. Simple Metrique.

II. Cawein's Ballads Bear Specific Marks of old Balladry. 


\section{Some Chareterigtiog of the Technique of}

\section{Old Bazladar. Wust}

\section{The Bartad Has Choper Onigin.}

The ballad as the name implies was originally inseparable from the dance; and was the oral literature of the people, or folk-poetry. Different members of a throng of dancers, one after another, may have chanted each his verse, composed on the spur of the moment, and the sum of these various contributions made the song. This is communal composition, * though each verse taken by itself is the work of an individual. A song, made in this way, is no man's property and has no individual author. The folk is its author. Ballads were at first always sung by the people, not like dance music simply to order their steps, but by their meaning and contents, to waken certain feelings. The dancers by their gestures and expressions take pains to show the various contents; as, for example, on the remote faroe Islands, where the community now is homogeneous to a remarkable degree**, when some fisherman has had a mishap with his boat, sturdy companions push him out into the dancing throng, and first one and then another. stanza is improvised upon the fatal theme, until a complete story of the situation with much repetition and dramatic action is attained. If the song wins general favor, so the good misionary says, it is remembered and sung from year to year, a genuine, traditional, and communal ballad.

(Foot-note) * With us communal composition has sunk into mere children's games as "Here te bo round" the booseberry bush" and "London Bridge is fali1ng dom:" For proof that games Isko these are descended from dances see "Games and Songs of American children." by W. W. Newell. ** The modern instances are taken from $N$. Annandale, "The Faroes and Iceland."... Oxford 1905. 
Ethnology has gathered an imnense amount of savage and half-savage literature in which, under certain limitations, the scholar can see a refreotion pi poetry in lts primitive form. The other sciences have given holp Bucher, a German professor of sociology, in hi Arbest and Rhythmus demonotrated the yast importance of this primitive verse in the early stages of man's social career, and the great part played by choral rhythm in the making of society itself.

The modern ecience of folklore has actually revealed amid byways of civilized life hoat of survivals in song; dance, chorals* of the fegtal year, refrains of labor and the march, all pointing to a time when such verse was found everywhere in Burope, and sprang from social conditions under which the universal gift of improvisation was otill mainly unchooked. The ballad was not confined to one country alone; for instance, there were many versions of the Maid and the palmer, which is a popular story of the samaritan woman in the gospel, in Danish, Faroe, Norwegian, Swedish, and Finnish. Lady Isabel and the Elf-Knight has currency in poland, Germany, Holland, Scandinaria, and among the Latin nations.

The English versions of The Maid Freed from the Gallows are defective. The same story is told in Finnish, Fsthonian, and variations of the theme occur in Russia; but the best ballad of the cycle is the Sicilian "Soibilia Nobili."

Gathering these characteristics of old balladry we may say that ballads were originally choral, communal, improvisatory, and popular in other countries.

(Foot-note) * Discussions about the relative priority of epic, Iyric, drama were settled by Mullenhoff who showed that choral poetry, inclusive of all three, is the primitive form: and here the German scholar joined hands with Aristotle. 


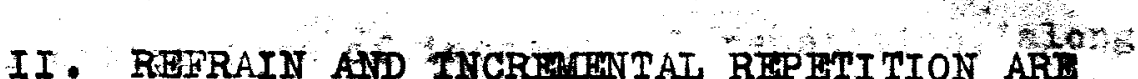

CHARACTERISIIG OF BAI IADRY.

Simple refrain is a very familiar feature of tho ballad. style and can never have been the invention of the solitary brooding poet of our modern conditions.

It presupposes a crowd of singers and dances, and as ballads get farther and farther away from the people, they tend to lose their refrains.

Dialogues and refrains make up many a ballad still, and they can be distinctly traced in the dialogues of older ballad versions.

Supplying the refrain, "Sheath and Knife" ends this:

There is ships of your father's sailing on the sea, (The trume biooms bonnio and says it is fair)

That wil bring as good a sheath and a knife unto thee

(And we'll never gang dom to the brume onie mair.

A simple trait, to which Francis Gummere in "The Popular Ballad" has given the apposite name of incremental repetition, is seen in The Twa Sisters and The Cruel Brother.

"O what will you leave to your father dear?"

"The silver-shod steed that brought me here."

"O what will you leave to your mother dear?"

"My velvet pali and my silken gear."

(Cruel Brother)

Then beapake the treble string,

"O yonder is my father, the king."

Then bespake the second string,

"O yonder sits my mother, the queen."

And then bespake the strings all three,

"O yonder is my sister that dromed mee."

(The .Twa sisters.) 
No better case of incremental repetition, along with refrain, sole material of the ballad, could be found than in the Danish Ballad, "Liden Kirstins" which echoos the vezy steps and motions of the dance, -

"Christine, Christine, tread a measure for mel" A allken sark I will give to theer."

"Christine, Christine, tread a measure for mel Silver-clasped shoes I will give to thee."

Hany other old ballads such as SirPatrick Spens and Mary Hamilton show repetition. Mary Hamilton, the heroine, is told to put on her robes of black or else her robes of brown, but refuses, repeating the negative for each, and adds:-

"But I'll put on my robes of white, To shine thro Edinbro town."

Incremental repetition leads up to the cause of tragedy, but in no dramatic situation; and with the relative-climax sub(ordinare.) In other words, the ballad, bound to set forth certain facts, chooses the old structural method and holds it to the end. In shorter compass, incremental repetition gives an emphatic effect.

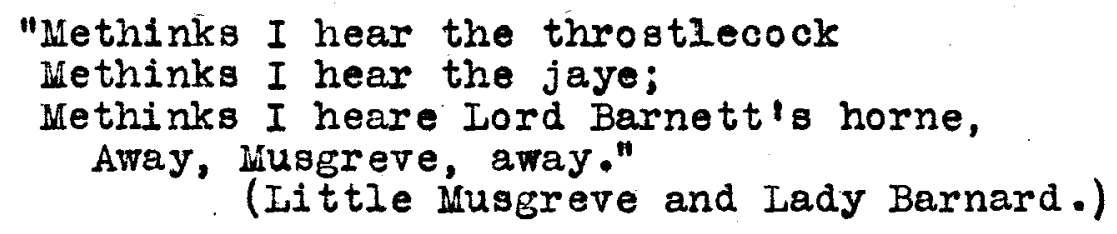

So common is repetition in all religious rites, that its vogue in poetry is now and then ascribed to a liturgical source rather than to the obvious communal and festal influence. (Foot-note) * Grundtvie, 5, $119 \mathrm{f}$. 
All poetry which begins in pubjic rites, in funeral, marriage, and festal occasions, has an insistent note of repetition, at first literal and then incremental.

In the old ritual of the Arval Brothers in Rome most of the verses are given three times in laborious repetition in its invocation to kare.

Old Corsican funeral songs were not only called lamenti, but ballate, because of the dance. "Make wide the circle," ran the ancient lament, "and dance the caracolu, for this sorrow is very sore," and it long held the incremental repetition of choral grief. 


\section{POPULAR MOTIFS OF OID BALIADS.}

Inglish and Scottioh ballads may be grouped according to their subjects, but the popular motifs we may generalize as follows:

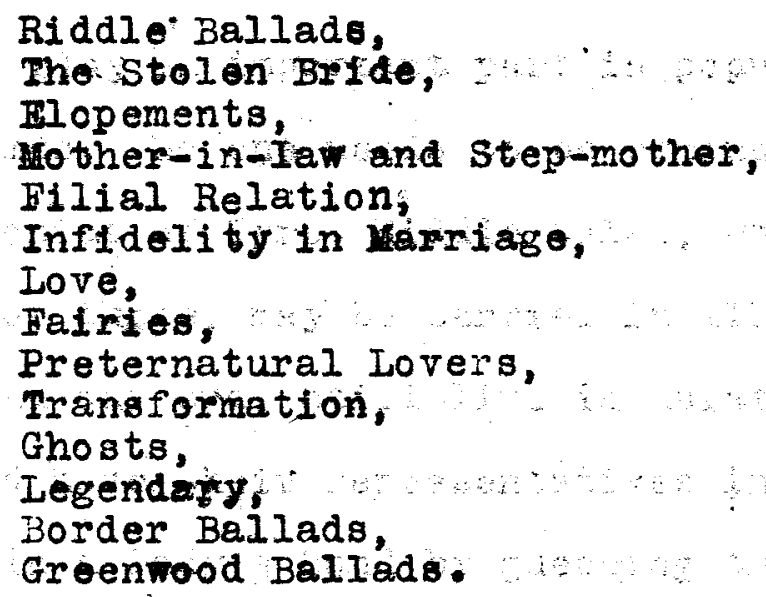




\section{Riddle Ballads.}

Professor child, who has made a study of old balladry, has placed riddle ballads, as the oldest, in the forefront of his collection.

Riddles play an important part in popular story from very remote times. No ode needs to be reminded of Samson, OEdipus, Apollonius of Tyre. Riddle tales, which, if not so old as the oldest of these, may be carrfed in all likelihood some centuries beyond our era, still live in Asiatic and Byropean traditions, and have their representatives in popular ballads. A suitor can win a lody's hand by guessing the riddle; or a clever lass can win a husband.

In an old scottish ballad a strange knight asks a widow for her three daughters; but he will choose the one who answers his riddles for his bride. The youngest girl wing the contest.

0 what is heigher nor the tree?

And what is deeper nor the sea?

Or what is greener nor the grass?

or what is waur (worse) nor a woman was?

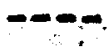

0 heaven is heigher nor the tree, And hell is deeper nor the sea.

The pies (poison) are greener nor the grass, And Clootie's (the devil). waur nor a woman was.

In the ballad of The Elfin Knight the knight imposes tasks, of which the girl stands acquitted if she can match each of them with another of no less difficulty. The elf is an 
interloper of some other ballad; the suitor should be mortal. "For thou must shape a sark to me, Wi thout any cut or heme, quoth he.

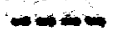

"Thou must ohape it knife - and - sheer - lesse, And also sue it needle - threedlesse."

Whereupon the maid replies:

"I have an aiker of good ley - land Which eyeth low by you. sea - strand.

"For thou must eare (plough) it with thy horn, So thou must sow it with thy corn.

"Thou must barn it in a mouse-holl, And thrash it into thy shoes soll.

\section{$-\cdots$}

"When thou hast gotten thy turns well done, Then come to me and get thy sark then."

The mere flash of riddle and answer, the thrust and parry of alternate demand for impossible things, might well satisfy a festal and choral throng.

other ballads of this class found in Child's collection of old ballads are:

Captain Wedderburn's Courtship. King John and the Bi shop. Proud Lady Margaret.

The Two Magicians. 


\section{Ballodsof the Stolen Bride.}

The robbery of bide of Bwoetheart was comnon material and found frequent dramatic, choral presentation in ballads of the primitive type like that Faroe song of the Frisian pirates and its Inglish version of "The Maid Freed from the Gallows."

A girl has falien into the hands of corsairs; and father, mother, sister, brother, all refuse to pay ransom except her lover.

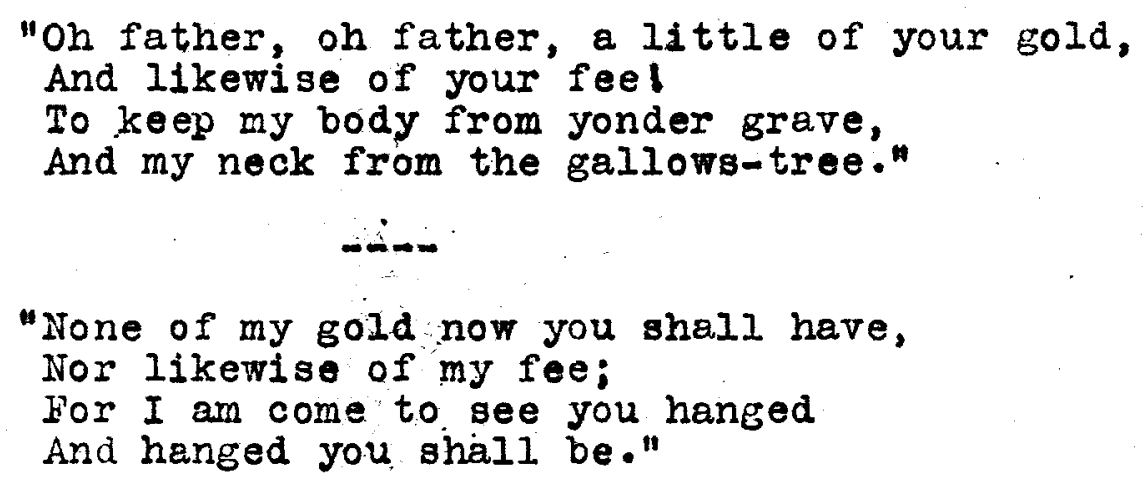

At last the sweetheart answers:

"Sorne of my gold now you shall have, And likewise of my fee, For I am come to see you saved; And saved you shall be."

Earl Brand, with many Scandinavian ballads of the same group, seems to belong among the numerous ramifications of the Hildesaga. Earl Brand elopes with the girl and they are pursued by her seven brothers. Almost the same incident occurs in the Denish "Ribold and Buildborg." (Grundtvig No. 82). 


\section{Barand.}

"Where hae been riting thi leng simmer-day Or where hae stolen this lady away?"

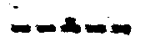

The lady looked over her left shouddor-bane;

"O guid Earl O Bran, we'Il all be taenl For yond are all my father's mon."

Another ballad of this type is linton, where the lovers are pursued by fifteen knights who are slain by Willie, her "ain true-love." 


\section{mopementas}

If olopement baliad mieh belong to tho older period, and show elements of romance or myth, linking them to versions current throughout Buxope, "Pair Annie" io good specimen. This ballad is preservod in Danish and swedigh. The story is also told in the Lai del Fresne of Marie de franee about 1180 .

\footnotetext{
"There came a knight out o'sr the sea And steald my sister away; The shame scoup (more) in his company And land whereer he gael"
}

"Gil Brenton" has the same romantic interest, and the same averting of tragedy in a closely allied plot. This ballad has many Scandinarian relatives. For example, see Grundtvie No. 274 . 


\section{Nother-in-lar and step-thother.}

In G1I Brenton the mother-in-law is jealous of her son's rights, but helpful in disentangling a bad knot and preventing tragedy. A German scholar and historian of ancient things, Professor schrader has recently written a little monograph * on the mother-in-law which deserves to be widely known. For a few cases of the bad mother-in-law in ballads see Professor Child's account of the "Testament" formula, I, $143 \mathrm{f}$. In the ballad "Williels Iady" oar bose schweigermutter stands out plain enough.

He's. wooed heptor her yellow hair

But his mother wrought her mickle care.

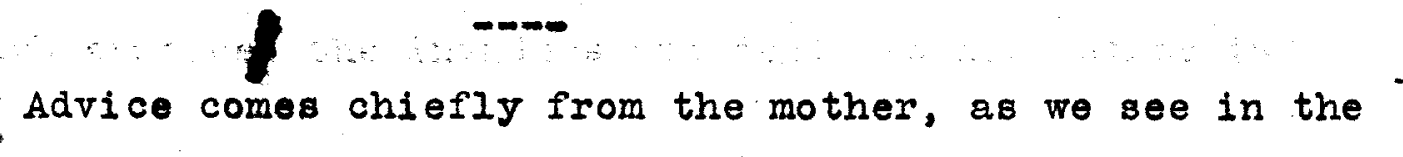
best version of Iord Thamas and Fair Annet. The mother of Iord Thomas tells him to marry the nut-browne girl because she has gold.

The nut-browne bride has gowd and gear, Fair Annet she has nane; And the little beauty fair Annet has 0 it will soon be gane.

\section{The step-mother.}

The figure of the stepmother flits dimly across the ballad. She gets short shrift in the "Laily Worm."

I was but seven year ald

Fan my mider she did dee,

Ny father married the warst woman

The wardle did ever see.

ote) * Die Schweigermutter und̄ der Hagestolz,Braunschweig, 1904 . $-185-$ 
She changed me to a lasly (loathsome) worme

That layes at the fitt of the tree,

And my sister Measry

To the makrell of the sea.

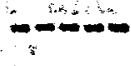

The stepmother appears in "Rose the Red and White

Iily" and "Lady Isabel" Istiden by her abusive stepmother to drink poisoned wine.

Come in, come Iñ, Lady Isabel,

And drink the wine with mo:

I have twa jewels in ae cotfer

And one of them IIII gie ye.

\section{F1ltal Relation.}

In the vigorous ald ballad of "Sir John Butler" Rllen, the daughter faces the invaders and declares her father is abroad.

Then dowa came plien Butler

And into her father's hall.

And then down came Hlien Butler,

And shee was laced in pall.

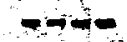

\section{Infidelity in Merriage.}

Ballads of this group are:

Our Goodman.

Child owlet.

Queen of Sootland.

The Bonny Birdy.

Old Robin of Portingale.

Iittle Musgrave and Lady Barnard.

\section{Love.}

Balladry knows that stolen love is sweet, and romances know that a happy ending is desired, Ballads with this theme 
are:

Child Vateres

The Gray Cock.

The Knlght and Shopherd's Daughter,

and others.

\section{Fairles.}

Commerce of mortal with creatures of the other world is among the oldest themes. In story. To kiss a fairy or a ghost puts a mortal within the jurisdiction of the dark powers; if he eats food in fairyland he will never come back to earth.

In the ballad "Thomas Rymer" the queen of Elfland takes with her a mortal loaf ard claret wine as refreshment for Thomas.

Thomas of Frceldoune, otherwise Thomas Rymer, had the gift of prophecy given to hlm by the Falry queen and his raticinations are cited by rarious chroniclers.

The queen of Blfland says to him:

"But I have a loaf here in my lap Ilkewise a bottle of claret wine; And now we go farther on, We'll rest a while; and ye may dine."

In the ballad of: Bonnie Annie the ship can not sail because
"There's fey fold in our ship, she winna sail for me." The Queen of Blfan's Nourice is another fairy type of ballad.

\section{Preternatural Lovers.}

"James Harris" or the "Daemon Lover" is a formidable broadside called "A Warning for Married Women, being an example of Mrs. Jane Reynolds," who was unfaithful to her husband and wooed away by the daemen. 
Thej had not sailed a league, a league,

A league but barely three,

When dismal grev his countenance

And drumlie grew his ee.

They had not salied a league, a league,

A league but barely three,

When she espied his cloven foot

And she nept right bitterlie.

"O. Whaten a mountain is Jon," she said, All so dreary with frast and snow? "

"O yon is the mountain of hell," he cried,

"Where you and I WiIl go."

A mermaid is loved and deserted in the ballad of lclerk Colv111:"

\section{Pransformation:}

1 Another group deals oimply with transformation by magio and a happy solution, if such is to be. Ballada of this group are:

\section{Kemp Ovrye,}

The Iaily Worm;

The Earl of Mar' Daughter, and others.

\section{Ghosts.}

Three ballads deal with the spirit world and the doings of the departed soul. In "The Unquiet Grave" a youth mourns at his sweetheart's grave for a year; then she speaks and complains that he disturbs her rest.

\section{He says:}

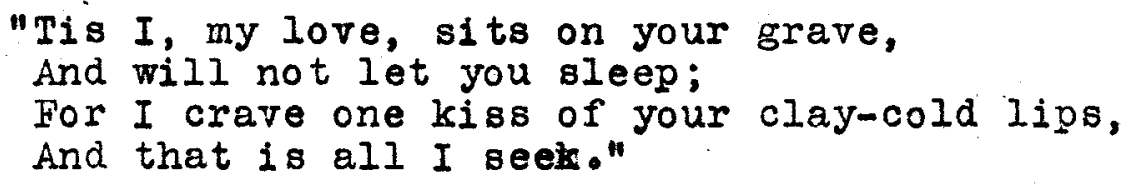




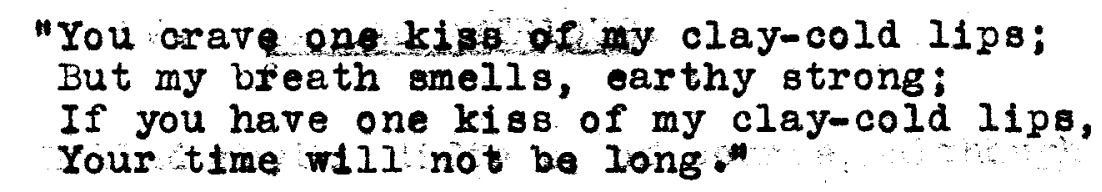

"Sweet William's Ghost" and "Chlld of Bristow" are others of this group. Spirits often demand back or give back plighted faith; in the "Child of Bristore" a dead father makes the effort twice.

\section{Legendary.}

Sacred tradition is the source of many ballads of this type, such as the "Cherry-Tree Carol," treating of Joseph, Wary and the Saviour; "The Carnal and the Crane" in which a crow wishes to know many things about the birth of Christ; and the "Bitter Withy." "Mary Hamilton," a fine old baliad, may be called a legend of the court of Mary queen of scots.

Mary Hamilton is to be hanged for ohild murder; and her defiance, her reckless flouting of a weak king, her reproach for the queen's ingratitud make her sufficlently individual.

"Yestreen I made queen Mary's bed, Kembed down her yollor hair; Is this the reward I am to get, -To tread the gallows-stairp"

\section{Border and Greenwood Ballads.}

"The Lads of Wamphray" and "Dick O' the Cow" are border ballads and the tales of Kobin Hood are ballads of the greenwood. 


\section{BATLAD UTRRIOUR .}

Ballad rhythm differs, of course, althugh a severe simplicity marks all ballads; but the rhythmical scheme shows no at tempt at originality. Ballad meters are almost uniform; the range is very olight; and they can all be reduced to variations of the immorial verse of four accents which savage poetry prefers and which may even lie behind later developments like the hexameter and the saturnian. The rour shythm accents are preserved in the old two-line ballads:

Gil Brenton has sent o'er the foam, He's woo'd a wife and brought her home.

We also find the four and three rhythm waves alternating, reducing the two lines to a septenarius.
But all this day Child Waters rode, She ran barefoote through the broome; Yet he was never so courteous, a knight As to say, "Put on your shoone:"
summarizing the general characteristics of the technique of old balladry we may say that ballads are of choral origin, communal, improvisatory, narrative, having refrain and incremental repetition, and treating of the themes herein described in simple four and three rhythm waves. 
(2) CAWEIN'S BATLADS BFAR GPBCIBIC MARKS OA OID BAILADRY.

His Ballads of the Stoton Bride.

Cawein has two ballads of the stolen bride motif; one is Childe Ronald and the other is Dead lian's Run.

Childe Ronald has twenty-seven stanzas. While a girl is waiting for her lover the knight carries her off to his towers, but because she loves another and can not free herself she plunges $\theta$ dagger into her heart. 
The ballad shows refrain, incremental repetition, and simple meter. We may well call it an American cousin to the old Scotch and English Ballads of G1I Brenton, Earl Brand, Frlinton, Eair Annie, and the Danish ballad of Ribold and Guldborg, with Scandinavian ramifications of the same theme.

Childe Ronald rode adown the wood, His spear upon his knee;

When, 10, he say a girl who stood Beneath an old oak tree.

$$
2 .
$$

Childe Ronald took her by the hand And drew her to his side "Thou shalt be a lady of the land; Now mount by me and ride."

$$
3 .
$$

"Unbusk, unbusk her, tire-girls !

Take off those rags, "quoth he.

"And clothe her body in silk and pearla,

And red gold, neck and knee."

$$
4 .
$$

"Unbusk, unbusk me, tire-maids, Now it hath come to lie Comb down my locks in simple braids, A simple majd an I:"

$$
5 .
$$

And there is wonder and there is wail, And pale is every guest; Childe Ronald too is pale, is pale, Far paler than the rest.

6.

The guests are gone: all wild and wan He saw the guests depart;

But she is wanest of them all, A dagerer in her heart. 
- on who are they? and whi ther away?

on whither do they ride?

Across the ror Id tall Jugment Day,

Childe Ronald and his bride!

This last stanza adds a touch of the supernatural wholly in accordance with the old ballads.

How let us compare the following stanza of Childe Ronald with some of the old ballads.

She needs must mount and through the wood

They rode unto the sea:

When in his towers at last she stood

A pale-faced girl was she.

\section{Barl Brana:}

He's mounted her on a milk-white steed, And himself on a dapple grey,

With a bugelet horn hung down by his side And lightly they rode away.

\section{Brinton.}

They d ridden a mle In that bonnie wood, They had not ridden but only ane, When there came fifteen of the boldest knights

That ever boor flesh, blind and bane.

\section{Fair Annie.}

There came a knisht out oer the sea, find steald my sister away.

The shame scoup (move) in his company And land whereer he gae.

Here we find a likeness in theme, rhythm, simple narrative, and in the third and fourth stanzas quoted in Childe Ronald refrain and incremental repetition. These surely are specific marks of old balladry. 
Belonglng to this same class is:

\section{Dead Man! Bur:}

He rode adown the auturn wood A man dark-eyed and brown;

A mountain girl before him stood Clad in a homeepun goma.

He holds her by one berry-bromwrist And by one berry brom hand

And he hath laughed at her and kissed Her cheek the sun hath tanned.

Then they galloped off

And they had passed:by Devil's Den, And come to Dead Ian's Run, When in the orueh rose up two men Each with a levelled gun.

"Sit fast, sit fast by me, sweetheart

The bank is begp to ridel

The bank is teep for a strong man's leap! And her eyes are staring wide.

This ends tragically for

Young hair of gold and a face death-cold

The wild stream sweeps away. 


\section{Athordanon Iover.".}

Cawein's Demon Lover may be classified with the Daemon lover of the old ballads, and "Lady Isabel and the Elf-Knight." Demon Lover.

The moon hangs white

In the winter night:

And the wind bloms fieros and free:

And Floranmane

Her place hath tal en

Beneath the haunted tree.

What is it whines?

What is it shines

With owlet-eldritch light?

With raven plume

Forth from the gloom

A man stalks atild and white.

What is it gleams?

What is it streams

So wan on Florimane?

The moonlit breaze?

Or his heartic she sees

Through the tak, like a burning stain?

Cawein has made this verse arrangement no doubt for artistic purposes, but the meter is the came.

The Daemon Lover: (o1d Balldd)

He's tane her by the milk-white hand, And ho' s throm her in the maln: Full five and-twenty hundred ships Perished all on the coast of Spain.

Lady Isabel and the flif-knight.

This maiden had scarcely these words spoken

Till in at her window the elf-knight was leaping. 
However sho charms htm to loopind reverses the impending tragedy.

With his aln sword-belt sae fast as sho ban (bound) him, With his ain dag-durk (dagger) sae sair as she dang him.

Here again we note marks of similarity in theme and tragic ending except in the last quotod ballad.

\section{The Headless Horseman.}

This ballad bears the spocific mediaeral mark in the popular belief that prayer and good deeds counteract the exiloone. It is a three line * balled with a refrain. The rider is pursued by a headless horseman mo 18 a demon dispolled by prayer.

And again I-looked behind, As I rode-

Dark as night and swift as wind

Towering no rodedbehind,

As I rode.

And my soul cried out in prayer

As I rode

Lo 1 the demon went in air,

When my soul called out in prayer

As I rode.:

The old ballad, "Sir Hugh, or The Jew"B Daughter," tells how a little child's prayers and devotion to the Blessed Virgin are rewarded after death. He $1 \mathrm{~s}$ murdered by the Jew's daughter and throm into Our Lady's well, yet he speaks to his mother when she comes to the well.

(Foot-note) * Old three-line-ballads are "The Faire Flower of Worth - umberland," "Sir Lionel," etc. 


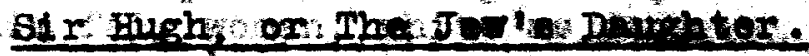

She neared Our Lady's deep draw-well,

Was fifty fathom deep:

"Whereer you bo, my pireet Sir Hugh, I pray you to me epoek."

"Gae hame, geo hame, ny mi ther dear, Prepare my winding shoet,

And at the back of merry Lincoln

The morn I 111 you meet."

Thi same miracle 10 celebrated in Chaucer's Prioresse's

Tale.

"My throte is kut unto my nekke boon,"

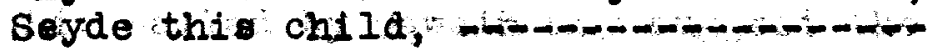

And for the worship of Christ's mooder deere

Yet may I sing " $O$ Alma ls loud and cleere.

In the old ballad, "Brown Robym's Confession," Brown

Robyn is carried to heaven by Our Blessed Lady and her Son on account of Robyn's good confession. The Blessed Lady says:

"It's for no honor ye did to me, Brown Robyn, It's for no good yo di a to mo;

But all is for your fair confession

You've made upon the sea."

\section{Fairy Ballad - Urfranda.}

Sir mid returns to his mife, Helis, after three years of war and tells her that while he was riding brough the woods at Hallowmas, the met wowah riding on palfrey, and farther dow the vale he saw an angel with the Holy Grail. This woman is Urganda, the Unknown, whom ho follows by her charm and who leads him to death.

"It was at Hallowmas I spurred

Through woods wherein no wild thing stirred, No sound of brook, no song of bird. 
"When softly dow a tangled way A dim fair roman, white as day,

Rode on palfreymiaty greys:

"I stared like one, who wild and paIe, Spurs hag-led throng the night and hail: When 101 adom a forost vale An angel with the Holy Gratl.

"Straight envard by ome highty will

Into the stream below the hill

She(Helis) hat hide. Then all was still."

While bending over the dead warrior Helis hears a voice

saying :

"Beware, Helis l bewarel beware

My cursol my kiso that is despaire

Kiss not his brow, lest unaware,

Helis, Helia, my curec be therel"

This ballad by cawein may suggest the old ballads of

"Thomas Rymer" and "Tam Lin," both of whom were carried away by the Queen of Fairies. Hovever they were permitted to return. But Sir Elid of Cawoin!s baklad has tragic fate.

\section{Thomas Bymer.}

True Thomas lay a'ox yond grassy bank, And he behezd atadi gay,

A ladie that was brisk and bold

come riding o'er the fernie brae.

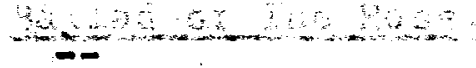

Her skirt was of the grass-green oilk,

Her mantle f the velvet fine,

At ilka tett of her boreats mene

Hung fifty silver belles and nine.

Thomeg takes her for the Queen of Heaven but ghe says to

him:

"O no, O no, True Thomas,". she says

"That name does not belong to me;

I am but the queen of fais Elfland

And I om come hera for to visit theo.

"But you maun go with me now, Thomas,

True Thomas, ye maun go th me;

Far ye maun serve me seven years 
"Thro weel or was as may chance to be."

\section{Tam Iin.}

And once it fell upon a day, A could day and a snell (keen)

When we were from the hunting come,

That frow yore I fell;

The queen of Falries bhe eaught me

In yon green hill to awell.

Cawein's baliad of Urgande runs parallel with Thomas Rymer and Tam Iin In the raot. thet a mortal was lured or taken away by a creature of the uriknown world. Here again is a likeness to the old ballads.

\section{BaIladó of Ioro.}

Cawein's ballads of love are:

Ballad of The Rose,

The Ride,

The Alcalde's Daughter,

Ballad of Iow-Ite-Down.

\section{Eallad of The Rose.}

Booted and spured he rode toward the west, A rose from the woman he loved the best, Lay warm with her kisses there in his breast And the battle beacons were burning.

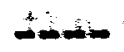

Again the cevallex turned and gazed, Then quick to his lips the rose he raised, And kissed it crying," Now God be praised," And help her there when mourning .

Quoth Hugh of the H11s, To yonder tree Now hang him high where she may see; Then bear this rose and message from meThe ravens feast at the turning." 


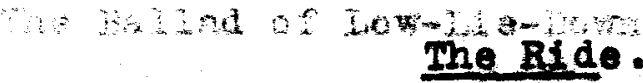

This young woman is happy because her old husband is dead and she rides to meet her Iover.

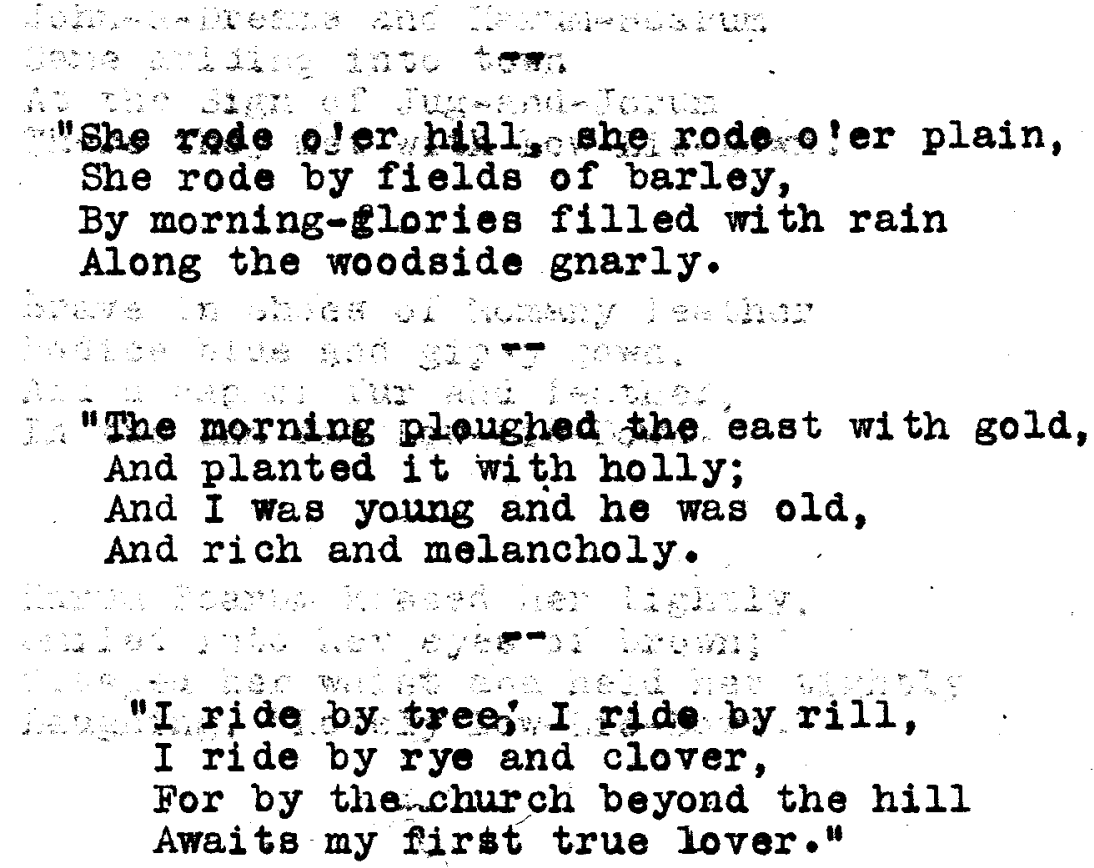

The Alcade's Daughter is a ballad of jealous love.

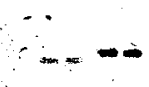

They tood in the balcony over

The old Toledo square;

And, reeping, she took for her lover

A red rose out of her hair.

And they ktoed ferewall and higher The moon made amber tho etr:

And she drew, for the treitor and liar A stiletto out of her hair.

One man at tho comner's turning Quite dead, in a moonlight band, In his heart a dagger burning, A red rose crushed in his hand. 
The Ballad of Low-Ile-Dow has for its theme fickle or. gypsy love. This savors of mountein Iife in Kentucky.

LOW-I10-DOWA.

Jolun-a-Dreams and Harum-Scarum

Came ariding into tow

At the Sign of Jug-and-Jorum

There they met wi th Low-Lie-Down.

Brave in shoes of Romany leather

Bodice blue and gipsy gom,

And a cap of fur and feather,

In the inn sat Low-Lid-Down.

Harum Scarum kissed her lightly, Smiled into her eyos of brow:

Clasped her waist and held her tightly

laughing, "Lovely Low-Lie-Down."

Then th many an oath and swagger

As a man of great renown,

on the board he clapped his dagger,

Called for sack and sat him down.

$-$

Harum-Scarum ridos off and leaves her and then John-aDreams begins his woolng.

For a little while she pondered:

Smiled! then said, "Let care go drown!"

Rose and kissed him. Forth they wandered,

John-a-Dreams and Low-Iie Down."

\section{Zyps of Z1rl.}

We may look upon this ballad as a Tyrolese offspring

of the Robin Hood Cycle of greemwood bellads. Both Zyps of Zirl axd Robin Hood are outlaws, yet they are true to their king. 

Kaj a

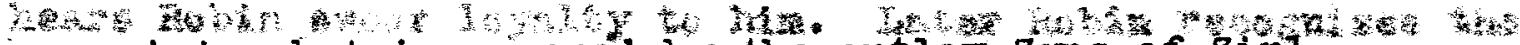

a precipice but is rescued by the outlan Zyps of Ziri.

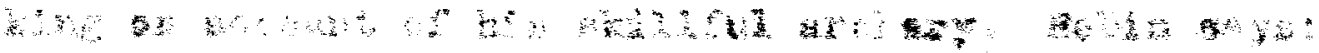

$$
\text { - }
$$

And tho is tho taje the burghers tell:

The Abbot of Witlar sogd at his cell

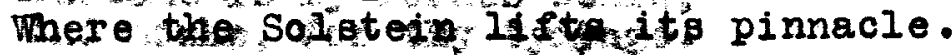

A chamois, he ogn, from apan, to span, had leapty and efterih leapt a man:

And he knen the the Kajgox Maximilian.

$$
\text { S }
$$

But seel though rash as the chamois he, His foot less sure. And verily

If the King should miss 1 . Jesueb. Marie!

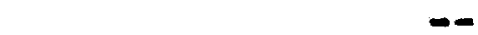

"The King hath missed" And look he falls! Rolls headlong ont to the headlong walls. What saint shall save him on whom he calls?

No voice of the eagle is that which rings ! And the shadow, a wiry man who swings Dow, dow, where the desperate Kaiser swings.

"By his cross-bow, baldric, and cap's black eurl," Quoth the Abbot below, "I know the churl. I

"Tis the hunted outlaw Zyps of Zirl."

And 10 ! the hand of the outlaw grasps The arm of the King- and death unclasps Its fleshless fingers from him who gaspo.

And safe at lest stand Kaiser and churl On the mountain path where masses curl And this the revenge of Zyps of Zirl. 


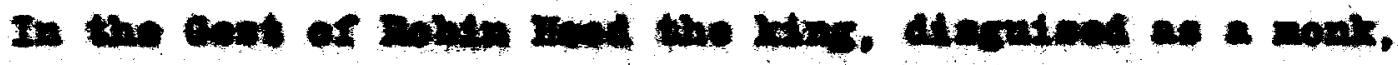

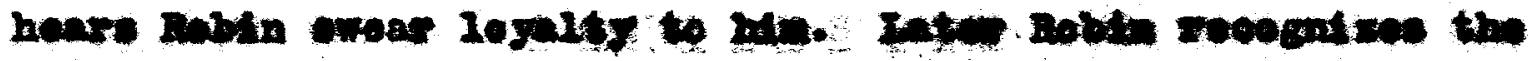

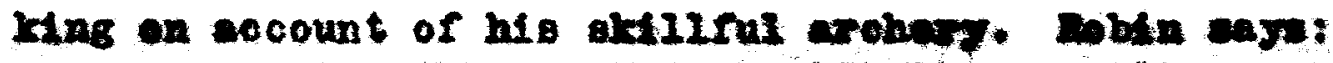

Grere wo in all the mere

8o well so I an my raves

Faloom is ny loxdes aede:

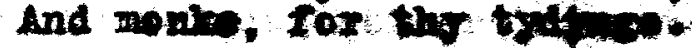

- Forth he ind our omely layper. Tuel fatre by the hanls: Hany $a$ dere there was sialn ind full rast endetame." 


\section{$\underline{\mathrm{C}} \underline{\mathrm{N}} \underline{\mathrm{E}} \underline{\mathrm{U}} \underline{\mathrm{S}} \underline{\mathrm{I}} \underline{\mathrm{O}} \underline{\mathrm{N}} \cdot$}

Having reviewed some of Cawein's ballads in connection with the old Inglish and Scotch ballads, it is plainly obvious, juding from the selections herein quoted, that his ballads bear specific marks of old beilladry in technique, that is being a narrative, having refrain and incremental repetition, dealing with popular motifs of old ballads, and possessing simple metrique. 